\title{
Cleanup Verification Package for the 118-F-3, Minor Construction Burial Ground
}

\author{
Prepared for the U.S. Department of Energy \\ by Washington Closure Hanford
}

December 2006 


\section{EXECUTIVE SUMMARY}

This cleanup verification package documents completion of remedial action for the 118-F-3, Minor Construction Burial Ground waste site. The 118-F-3 site is located within the 100-FR-2 Operable Unit in the 100-F Area of the Hanford Site in southeastern Washington State. This site operated during 1952 and, prior to remediation, was as an open field covered with cobbles, with no vegetation growing on the surface. The burial ground measured approximately $55.3 \mathrm{~m}(175 \mathrm{ft})$ by $15.2 \mathrm{~m}(50 \mathrm{ft})$ by $4.5 \mathrm{~m}(15 \mathrm{ft})$ deep (DOE-RL 2001). The site received irradiated reactor parts that were removed during the conversion of the 105-F Reactor from the Liquid $3 X$ to the Ball $3 X$ Project safety systems. The burial ground received mostly

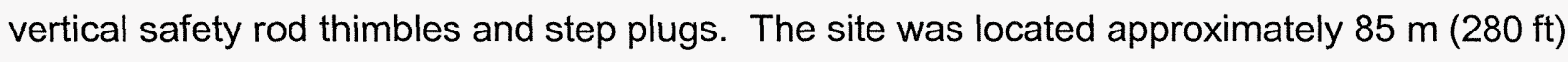
southwest of the 105-F Reactor Building.

Remedial action at the 118-F-3 site began on January 31, 2006 with load out of waste material completed on May 23, 2006. Remedial activities included removal of metal and concrete debris from the burial ground along with the underlying contaminated soil. Results of the sampling, laboratory analyses, and data evaluations for the 118-F-3 site (which includes the remediation footprint, overburden [stockpiled soil], and the above-cleanup-level staging pile footprint) indicate that all remedial action objectives and goals for direct exposure, protection of groundwater, and protection of the Columbia River have been met (see Table ES-1).

The site meets cleanup standards and has been reclassified as "interim closed out" in accordance with the Hanford Federal Facility Agreement and Consent Order (Ecology et al. 1989) and the Waste Site Reclassification Guideline TPA-MP-14 (RL-TPA-90-0001) (DOE-RL 1998). A copy of the waste site reclassification form is included as Attachment ES-1. 


\section{Table ES-1. Summary of Cleanup Verification Results for the 118-F-3 Burial Ground. (2 pages)}

\begin{tabular}{|c|c|c|c|c|}
\hline $\begin{array}{l}\text { Regulatory } \\
\text { Requirement }\end{array}$ & Remedial Action Goals & Results & $\begin{array}{l}\text { Remedial } \\
\text { Action } \\
\text { Objectives } \\
\text { Attained? }\end{array}$ & Ref. \\
\hline $\begin{array}{l}\text { Direct Exposure - } \\
\text { Radionuclides }\end{array}$ & $\begin{array}{l}\text { 1. Attain } 15 \mathrm{mrem} / \mathrm{yr} \text { dose rate } \\
\text { above background over } \\
1,000 \text { years. }\end{array}$ & $\begin{array}{l}\text { 1. All cumulative radionuclide } \\
\text { activities are below the } \\
\text { cumulative } 15 \mathrm{mrem} / \mathrm{yr} \text { dose rate. }\end{array}$ & Yes & $\mathrm{d}, \mathrm{e}$ \\
\hline $\begin{array}{l}\text { Direct Exposure - } \\
\text { Nonradionuclides }\end{array}$ & 1. Attain individual COC RAGs. & $\begin{array}{l}\text { 1. All individual COC concentrations } \\
\text { are below the direct exposure } \\
\text { criteria. }\end{array}$ & Yes & d,e \\
\hline \multirow{4}{*}{$\begin{array}{l}\text { Meet } \\
\text { Nonradionuclide } \\
\text { Risk } \\
\text { Requirements }\end{array}$} & $\begin{array}{l}\text { 1. Hazard quotient of }<1 \text { for } \\
\text { noncarcinogens. }\end{array}$ & $\begin{array}{l}\text { 1. The individual hazard quotient } \\
\text { for boron is }<1 \text {. }\end{array}$ & Yes & $\mathrm{e}$ \\
\hline & $\begin{array}{l}\text { 2. Cumulative hazard quotient of }<1 \\
\text { for noncarcinogens. }\end{array}$ & $\begin{array}{l}\text { 2. Cumulative hazard quotient } \\
\text { calculation not required. }\end{array}$ & $\mathrm{N} / \mathrm{A}$ & e \\
\hline & $\begin{array}{l}\text { 3. Excess cancer risk of }<1 \times 10^{-6} \\
\text { for individual carcinogens. }\end{array}$ & $\begin{array}{l}\text { 3. There are no carcinogenic } \\
\text { nonradionuclide COCs for this } \\
\text { site. }\end{array}$ & N/A & d,e \\
\hline & $\begin{array}{l}\text { 4. Attain a total excess cancer risk } \\
\text { of }<1 \times 10^{-5} \text { for carcinogens. }\end{array}$ & $\begin{array}{l}\text { 4. There are no carcinogenic } \\
\text { nonradionuclide COCs for this } \\
\text { site. }\end{array}$ & N/A & $\mathrm{de}$ \\
\hline \multirow[t]{4}{*}{$\begin{array}{l}\text { Groundwater/ } \\
\text { River Protection - } \\
\text { Radionuclides }\end{array}$} & $\begin{array}{l}\text { 1. Attain single COC groundwater } \\
\text { and river protection RAGs. }\end{array}$ & $\begin{array}{l}\text { 1. Groundwater and river RAGs for } \\
\text { the radionuclide COCs have been } \\
\text { attained. }\end{array}$ & \multirow[b]{2}{*}{ Yes } & d,e \\
\hline & $\begin{array}{l}\text { 2. Attain National Primary Drinking } \\
\text { Water Standards: } 4 \mathrm{mrem} / \mathrm{yr} \\
\text { (beta/gamma) dose rate to target } \\
\text { receptor/organs. }\end{array}$ & $\begin{array}{l}\text { 2. RESRAD modeling predicts that } \\
\text { residual concentrations of the } \\
\text { detected radionuclide COCs meet } \\
\text { the dose rate limit of } 4 \mathrm{mrem} / \mathrm{yr} \text {. }\end{array}$ & & d \\
\hline & $\begin{array}{l}\text { 3. Meet drinking water standards for } \\
\text { alpha emitters: the more } \\
\text { stringent of the } 15 \mathrm{pCi} / \mathrm{L} \mathrm{MCL} \\
\text { or } 1 / 25 \text { th of the derived } \\
\text { concentration guide per } \\
\text { DOE Order } 5400.5 \text {. }^{\mathrm{b}} \\
\end{array}$ & $\begin{array}{l}\text { 3. There are no alpha-emitting } \\
\text { COCs for this site. }\end{array}$ & $\mathrm{N} / \mathrm{A}$ & \\
\hline & $\begin{array}{l}\text { 4. Meet total uranium standard of } \\
21.2 \mathrm{pCi} / \mathrm{L} .\end{array}$ & $\begin{array}{l}\text { 4. Uranium is not a } \mathrm{COC} \text { for this } \\
\text { site. }\end{array}$ & N/A & \\
\hline
\end{tabular}




\title{
Table ES-1. Summary of Cleanup Verification Results for the 118-F-3 Burial Ground. (2 pages)
}

\begin{tabular}{|c|c|c|c|c|}
\hline $\begin{array}{l}\text { Groundwaterl } \\
\text { River Protection - } \\
\text { Nonradionuclides }\end{array}$ & $\begin{array}{l}\text { 1. Attain individual nonradionuclide } \\
\text { groundwater and river cleanup } \\
\text { requirements. }\end{array}$ & $\begin{array}{l}\text { 1. Barium exceeded groundwater } \\
\text { and/or river protection RAGs in } \\
\text { the focused sample. However, } \\
\text { results of the } 100 \text { Area } \\
\text { Analogous Sites RESRAD } \\
\text { Calculations (BHI 2005) indicate } \\
\text { that this constituent will not reach } \\
\text { groundwater (and therefore, the } \\
\text { Columbia River) within } \\
1,000 \text { years. Thus, the residual } \\
\text { concentrations achieve the RAOs } \\
\text { for groundwater and river } \\
\text { protection. }\end{array}$ & Yes & $d$ \\
\hline $\begin{array}{l}\text { Other supporting } \\
\text { Information }\end{array}$ & \multicolumn{3}{|c|}{$\begin{array}{l}\text { 118-F-3 cleanup verification } 95 \% \text { UCL calculation (Appendix C). }{ }^{e} \\
118-F-3 \text { cleanup verification sample location design (Appendix C). }{ }^{g}\end{array}$} & \\
\hline
\end{tabular} \\ a "National Primary Drinking Water Regulations" (40 Code of Federal Regulations 141). \\ ${ }^{b}$ Radiation Protection of the Public and the Environment (DOE Order 5400.5). \\ c Based on the isotopic distribution of uranium in the Hanford Site background, the $30 \mu \mathrm{g} / \mathrm{L} \mathrm{MCL} \mathrm{(65} \mathrm{Federal} \mathrm{Register} \mathrm{76708)}$ \\ corresponds to $21.2 \mathrm{pCi} / \mathrm{L}$. Concentration-to-activity calculations are documented in Calculation of Total Uranium Activity \\ Corresponding to a Maximum Contaminant Level for Total Uranium of 30 Micrograms per Liter in Groundwater, 0100X-CA-V0038 \\ (BHI 2001). \\ d The Cleanup Verification Package for the 118-F-3, Minor Construction Burial Ground, CVP-2006-00008, Washington Closure \\ Hanford, Richland, Washington. \\ e 118-F-3 Waste Site Cleanup Verification 95\% UCL Calculations, 0100F-CA-V0273, Rev. 0, Washington Closure Hanford, \\ Richland, Washington. \\ ${ }^{f} \mathrm{BHI} 2005$ \\ $g$ 118-F-3 Shallow Zone, ACL, and BCL Overburden Sampling Plan, 0100F-CA-V0268, Rev. 0, Washington Closure Hanford, \\ Richland, Washington.

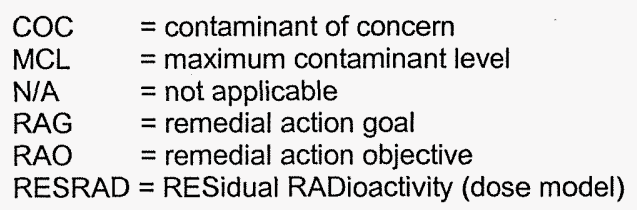


CVP-2006-00008

Rev.0

ES-4 
Waste Site Reclassification Form

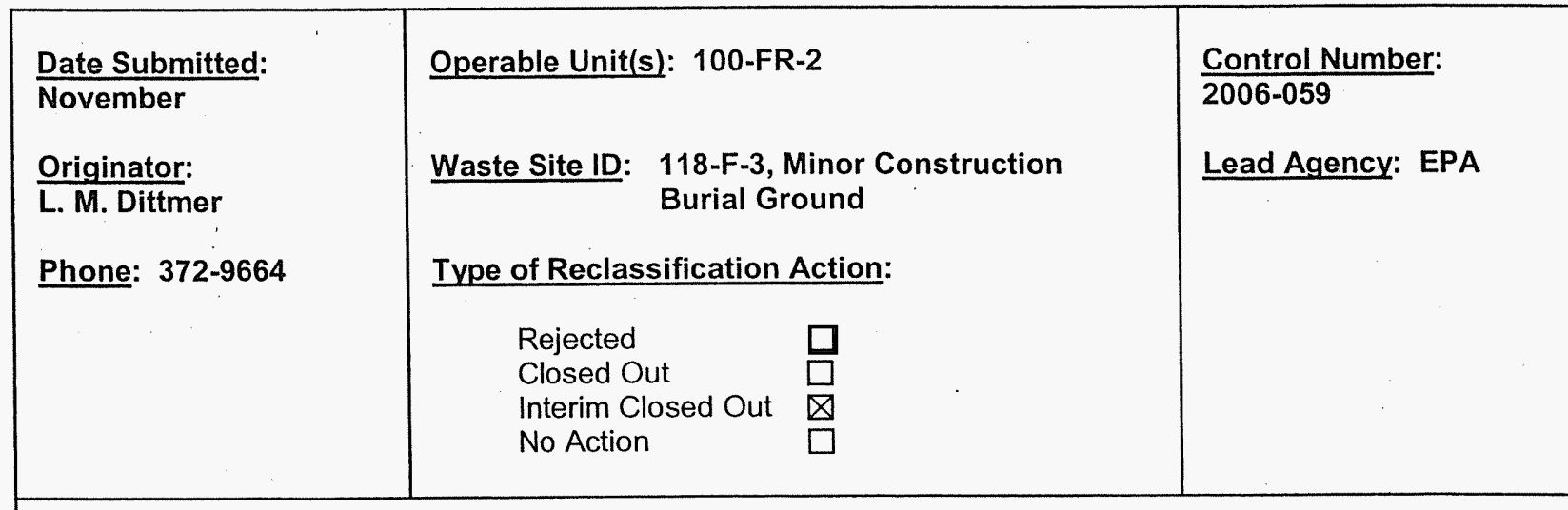

This form documents agreement among the parties listed below authorizing classification of the subject unit as rejected, closed out, or no action and authorizing backfill of the site, if appropriate. Final removal from the National Priorities List (NPL) of no action or closed-out sites will occur at a future date.

\section{Description of current waste site condition:}

Remedial action at this site has been performed in accordance with remedial action objectives and goals established by the U.S. Environmental Protection Agency and the Washington State Department of Ecology, in concurrence with the U.S. Department of Energy, Richland Operations Office. The selected remedial action involved (1) excavating the site to the extent required to meet specified soil cleanup levels, (2) disposing of contaminated excavation materials at the Environmental Restoration Disposal Facility at the 200 Area of the Hanford Site, and (3) backfilling the site with clean soil to adjacent grade elevations. These excavation and disposal activities have been completed.

\section{Basis for reclassification:}

The results of verification sampling of the soils at the $118-\mathrm{F}-3$ waste site demonstrated that residual contaminant concentrations do not preclude any future uses (as bounded by the rural-residential scenario) and allow for

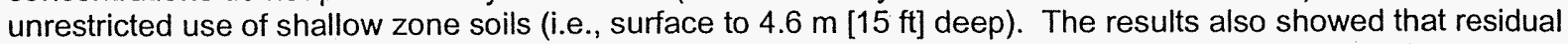
contaminant concentrations are protective of groundwater and the Columbia River. The waste site does not have a deep zone; therefore, no institutional controls are required. The basis for reclassification is described in detail in the Cleanup Verification Package for the 118-F-3, Minor Construction Burial Ground (CVP-2006-00008), Washington Closure Hanford, Richland, Washington.

D. C. Smith

DOE Project Manager

N/A

Ecology Project Manager

R. A. Lobos

EPA Project Manager
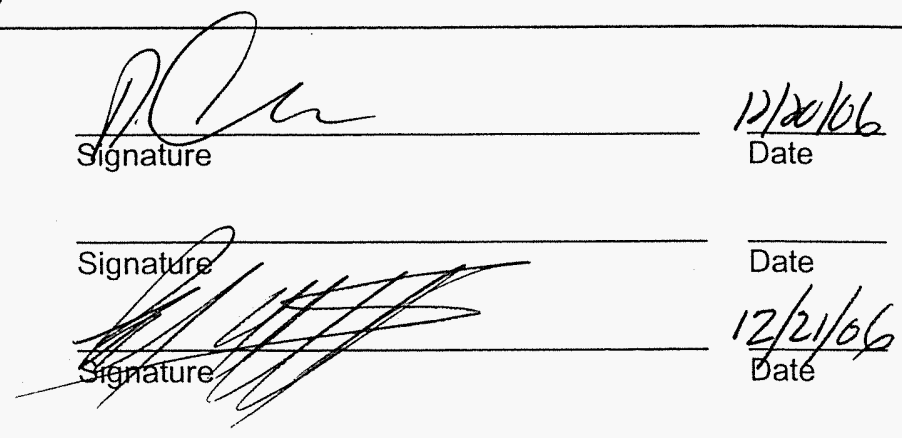
CVP-2006-00008

Rev.0

ES-6 


\section{CONTENTS}

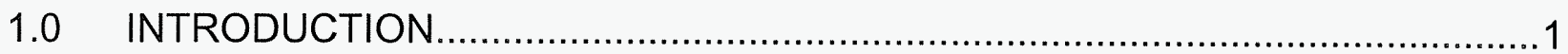

2.0 SITE DESCRIPTION AND SUPPORTING INFORMATION …..........................

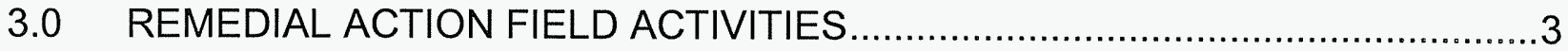

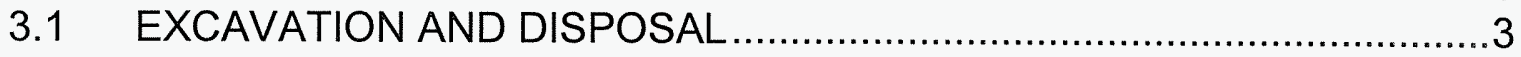

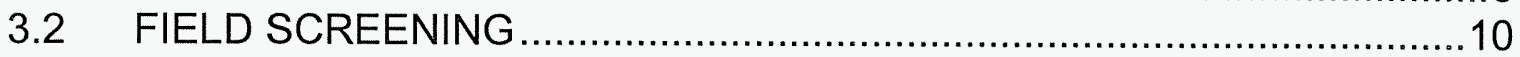

$3.3 \quad$ FOCUSED SAMPLING AND ANALYSIS .........................................13

3.4 CLEANUP VERIFICATION SAMPLING AND ANALYSIS .....................13

4.0 CLEANUP VERIFICATION DATA EVALUATION ..........................................15

$4.1 \quad$ DATA QUALITY ASSESSMENT PROCESS .........................................15

4.2 CONTAMINANTS OF CONCERN 95\% UPPER CONFIDENCE LIMIT ...15

$4.3 \quad$ FOCUSED SAMPLE RESULTS .....................................................16

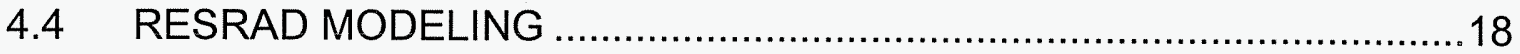

5.0 EVALUATION OF REMEDIAL ACTION GOAL ATTAINMENT ….....................18

5.1 DIRECT EXPOSURE SOIL REMEDIAL ACTION GOALS ATTAINED ....18

5.1.1 Radionuclides .................................................................... 18

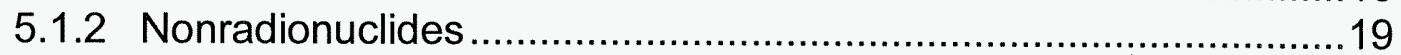

5.2 GROUNDWATER REMEDIAL ACTION GOALS ATTAINED ..................21

5.2.1 Radionuclides .................................................................21

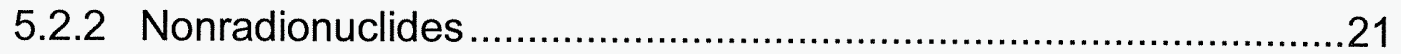

5.3 COLUMBIA RIVER REMEDIAL ACTION GOALS ATTAINED .................23

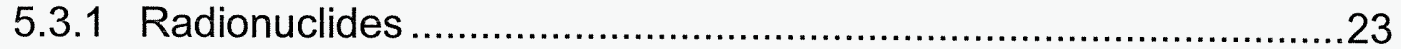

5.3.2 Nonradionuclides .................................................................23

5.4 WAC 173-340 THREE-PART TEST FOR NONRADIONUCLIDES ..........23

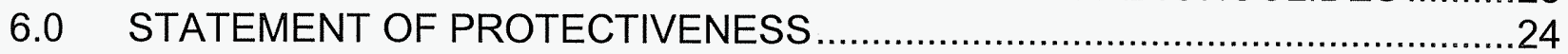

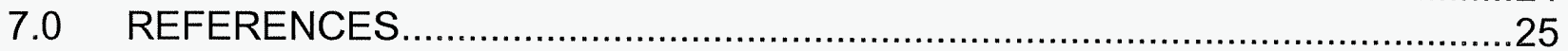

\section{APPENDICES}

A SUMMARY OF VERIFICATION SOIL SAMPLING AND ANALYTICAL RESULTS

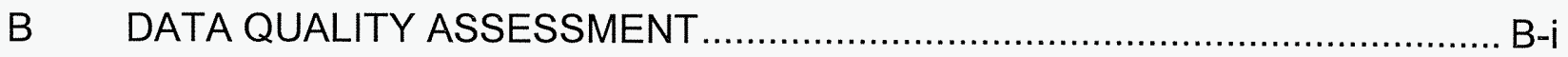

C CALCULATION BRIEF EXCERPTS …........................................................

C1 118-F-3 Shallow Zone, ACL, and BCL Overburden Sampling Plan, 0100F-CA-V0268

C2 118-F-3 Waste Site Cleanup Verification 95\% UCL Calculations, 0100F-CA-V0273 


\section{FIGURES}

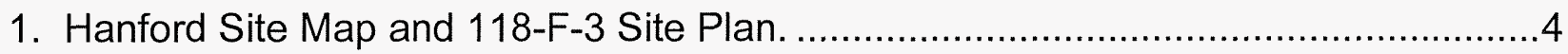

2. 118-F-3 Pre-Remediation Topographic Map....................................................

3. 118-F-3 Post-Remediation Topographic Map Showing Black Surface Ash and

Focused Sample Location..............................................................................

4. Photograph of 118-F-3 Burial Ground Remediation Debris. ..................................

5. Photograph of 118-F-3 Burial Ground Remediation Debris. ................................. 8

6. Photograph of 118-F-3 Remediation Footprint................................................. 9

7. GPERS Radiological Survey Gamma Track Map of the 118-F-3 Remediation

Footprint (May 5, 2006)

8. GPERS Radiological Survey Gamma Track Map of the 118-F-3 Remediation Footprint (May 15, 2006)

9. Photograph of Black Surface Ash Located at Northern End of Remediation Footprint.14

\section{TABLES}

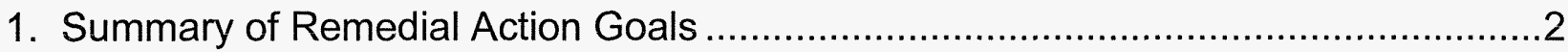

2. Cleanup Verification Data Set. ...................................................................... 16

3. Comparison of Focused Sample Results to Remedial Action Goals. .....................17

4. Attainment of Radionuclide Direct Exposure RAG for the Shallow Zone Remediation Footprint.

5. Attainment of Radionuclide Direct Exposure RAG for the ACL Staging Pile Footprint.

6. Attainment of Nonradionuclide Direct Exposure Standards.

7. Attainment of Nonradionuclide Remedial Action Goals for Protection of Groundwater and the Columbia River.

8. Application of the WAC 173-340 Three-Part Test. 


\section{ACRONYMS AND ABBREVIATIONS}

$\begin{array}{ll}\text { ACL } & \text { above cleanup level } \\ \text { COC } & \text { contaminant of concern } \\ \text { DQA } & \text { data quality assessment } \\ \text { EPA } & \text { U.S. Environmental Protection Agency } \\ \text { ERDF } & \text { Environmental Restoration Disposal Facility } \\ \text { GPERS } & \text { Global Positioning Environmental Radiological Surveyor } \\ \text { RAG } & \text { remedial action goal } \\ \text { RDR/RAWP } & \text { remedial design report/remedial action work plan } \\ \text { RESRAD } & \text { RESidual RADioactivity (dose assessment model) } \\ \text { ROD } & \text { record of decision } \\ \text { SAP } & \text { sampling and analysis plan } \\ \text { UCL } & \text { upper confidence limit } \\ \text { WAC } & \text { Washington Administrative Code }\end{array}$


CVP-2006-00008

Rev.0 


\subsection{INTRODUCTION}

The purpose of this cleanup verification package is to document that the 118-F-3 waste site was remediated in accordance with the Record of Decision for the 100-BC-1, 100-BC-2, 100-DR-1, 100-DR-2, 100-FR-2, 100-HR-2, and 100-KR-2 Operable Units, Hanford Site (100 Area Burial Grounds), Benton County, Washington (ROD) (EPA 2000). Remedial action objectives and goals for the 118-F-3 site were established by the U.S. Environmental Protection Agency (EPA) and the U.S. Department of Energy, Richland Operations Office, in concurrence with the Washington State Department of Ecology. These goals and objectives are documented in the 100 Area Burial Grounds ROD (EPA 2000) and the Remedial Design Report/Remedial Action Work Plan for the 100 Area (RDR/RAWP) (DOE-RL 2005). The ROD (EPA 2000) provides the U.S. Department of Energy, Richland Operations Office the authority, guidance, and objectives to conduct this remedial action.

The preferred remedy specified in the ROD (EPA 2000) and conducted for the 118-F-3 site included: (1) excavating the site to the extent required to meet specified soil cleanup levels, (2) disposing of contaminated excavation materials at the Environmental Restoration Disposal Facility (ERDF) at the 200 Areas of the Hanford Site, and (3) backfilling the site with clean soil from the overburden (stockpiled soil) and the100-F Area borrow pit to an average adjacent grade elevation. Excavation was driven by remedial action objectives for direct exposure, protection of groundwater, and protection of the Columbia River. For the respective points of compliance, the remedial action goals (RAGs) summarized in Table 1 were established for the radionuclide and nonradionuclide contaminants of concern (COCs). Waste site COCs were identified in the RDR/RAWP (DOE-RL 2005) and included cobalt-60 and nickel-63. Barium, boron, and strontium-90 were detected in the remaining black surface ash located at the northern end of the 118-F-3 burial ground and, as such, were added as waste site COCs. Additionally, cesium-137 was detected in the verification samples and was added as a COC. The COCs for the 118-F-3 waste site are barium, boron, cobalt-60, cesium-137, nickel-63, and strontium-90 and are provided in Table 1.

Soil cleanup levels were established in the interim action ROD based on a limited ecological risk assessment. Although not required by the ROD (EPA 2000), a screening comparison against ecological risk screening levels has been made for the site COCs, as identified in the RDR/RAWP. The highest exceedance values were observed in the focused sample collected of the black surface ash located north of the 118-F-3 waste site. Barium, boron, and selenium exceeded screening level values. However, exceedance of screening values does not necessarily indicate the existence of risk to ecological receptors. Barium, boron, and selenium are below the range for generic background soil values: (barium: $<70$ to $3000 \mathrm{ppm}$ ), (boron: $<20$ to $150 \mathrm{ppm}$ ), (selenium : $<0.1$ to $4.0 \mathrm{ppm}$ ), provided in the Risk Assessment Information System (RAIS) database < http://risk.Isd.ornl.gov >. The exceedance of soil values by these constituents at the site will be evaluated in the context of additional lines of evidence for ecological effects. A baseline risk assessment for the river corridor portion of the Hanford Site began in 2004, which includes a more complete quantitative ecological risk assessment. That baseline risk assessment will be used as part of the final closeout decision for this site. 
Table 1. Summary of Remedial Action Goals. ${ }^{a}$

\begin{tabular}{|c|c|c|c|}
\hline cocs & $\begin{array}{c}\text { Direct Exposure } \\
\text { RAG }\end{array}$ & $\begin{array}{c}\text { Groundwater } \\
\text { Protection RAG } \\
\text { (pCi/L) }\end{array}$ & $\begin{array}{l}\text { Columbia River } \\
\text { Protection RAG } \\
\text { (pCi/L) }\end{array}$ \\
\hline \multicolumn{4}{|c|}{ Radionuclides } \\
\hline Cobalt-60 & \multirow{4}{*}{$\begin{array}{l}15 \mathrm{mrem} / \mathrm{yr} \\
\left(\text { (cumulative) }^{\mathrm{b}}\right.\end{array}$} & \multirow{3}{*}{$\begin{array}{c}4 \mathrm{mrem} / \mathrm{yr} \\
\text { (cumulative) }^{\mathrm{c}}\end{array}$} & \multirow{3}{*}{$\begin{array}{c}4 \mathrm{mrem} / \mathrm{yr} \\
\text { (cumulative) }^{\mathrm{c}}\end{array}$} \\
\hline Cesium-137 & & & \\
\hline Nickel-63 & & & \\
\hline Strontium-90 & & $8^{\mathrm{d}, e}$ & $8^{\mathrm{d}, \mathrm{e}}$ \\
\hline cocs & $\begin{array}{c}\text { Direct Exposure } \\
\text { RAGs } \\
(\mathrm{mg} / \mathrm{kg})\end{array}$ & $\begin{array}{c}\text { Soil RAG for } \\
\text { Groundwater Protection } \\
(\mathrm{mg} / \mathrm{kg})\end{array}$ & $\begin{array}{l}\text { Soil RAG for Columbia } \\
\text { River Protection } \\
\text { (mg/kg) }\end{array}$ \\
\hline \multicolumn{4}{|c|}{ Nonradionuclides } \\
\hline Barium & $5,600^{f}$ & $132^{g, h}$ & $224^{i}$ \\
\hline Boron $^{j}$ & 16,000 & 320 & $--^{k}$ \\
\hline
\end{tabular}

a Lookup values and RAGs obtained from the Remedial Design Report/Remedial Action Work Plan for the 100 Area (RDR/RAWP) (DOE-RL 2005) or calculated per WAC 173-340-720, WAC 173-340-730, and WAC 173-340-740, Method B, 1996 , unless otherwise noted.

b Lookup values that correspond to the $15 \mathrm{mrem} / \mathrm{yr}$ dose rate are based on a generic site model and are presented in the 100 Area RDR/RAWP (DOE-RL 2005).

c Lookup values based on individual radionuclide $4 \mathrm{mrem} / \mathrm{yr}$ dose rate equivalent for beta and gamma emitters per National Drinking water standards as presented in the 100 Area Burial Grounds Remedial Action Sampling and Analysis Plan (DOE-RL 2001). Alpha emitters must meet drinking water standards based on the more conservative of the $15 \mathrm{pCi} / \mathrm{L}$ maximum contaminant level or $1 / 25$ th of the derived concentration guide per DOE Order 5400.5 .

d Strontium-90 contributes to the $4 \mathrm{mrem} / \mathrm{yr}$ (cumulative) RAG for groundwater and river protection.

e Promulgated groundwater protection standard (40 CFR 141).

f Noncarcinogenic cleanup level calculated from WAC 173-340-740(3), 1996 (Method B for soils) (as presented in the 100 Area RDR/RAWP [DOE-RL 2005]). Updated oral reference dose values (as provided in IRIS) yield Method B direct exposure RAG values of $16,000 \mathrm{mg} / \mathrm{kg}$ and $120,000 \mathrm{mg} / \mathrm{kg}$ for barium.

g Where cleanup levels are less than background, cleanup levels default to background (WAC 173-340-700[4][d]) (1996).

h Barium soil cleanup level for groundwater protection calculated from WAC 173-340-740(3)(a)(ii)(A), 1996 ("100 times rule") and WAC 173-340-720(3), 1996 (Method B for groundwater) is $112 \mathrm{mg} / \mathrm{kg}$ (as presented in the 100 Area RDR/RAWP [DOE-RL 2005]). The updated oral reference dose value (as provided in IRIS) yields a Method B groundwater cleanup criteria of $7 \mathrm{mg} / \mathrm{L}$, as compared to the more restrictive MCL of $2 \mathrm{mg} / \mathrm{L}$ (40 CFR 141). Per WAC 173-340-740(3)(a)(ii)(A), 1996 ("100 times rule"), the most restrictive updated soil cleanup level for groundwater protection would be $200 \mathrm{mg} / \mathrm{kg}$.

i Barium soil cleanup level for river protection calculated from WAC 173-340-740(3)(a)(ii)(A), 1996 ("100 times rule"), a DAF of 2, and WAC 173-340-720(3), 1996 (Method B for groundwater) is $224 \mathrm{mg} / \mathrm{kg}$ (as presented in the 100 Area RDR/RAWP [DOE-RL 2005]). No surface water bioconcentration factor is available for barium and no ambient water quality criteria exists separate from the previous drinking water standard; therefore, no WAC 173-340-730(3), 1996 (Method B for surface waters) value can be determined.

i No Hanford Site-specific or Washington State background value available.

${ }^{k}$ No cleanup level is available from the Ecology Cleanup Levels and Risk Calculations database (Ecology 2005), and no bioconcentration factor or AWQC values are available to calculate cleanup levels (WAC 173-340-730(3)(a)(iii), 1996 [Method $B$ for surface waters]).

AWQC = ambient water quality criteria

$\mathrm{CFR}=$ Code of Federal Regulations

$\mathrm{COC}=$ contaminant of concern

DAF = dilution attenuation factor

IRIS = Integrated Risk Information System

$\mathrm{MCL}$ = maximum contaminant level

RAG = remedial action goal

RDL $\quad=$ required detection limit

RDR/RAWP = remedial design report/remedial action work plan

WAC = Washington Administrative Code 


\subsection{SITE DESCRIPTION AND SUPPORTING INFORMATION}

The 118-F-3 site is located in the 100-FR-2 Operable Unit of the 100-F Area at the Hanford Site. The site is located approximately $85 \mathrm{~m}(280 \mathrm{ft})$ southwest of the 105-F Reactor Building (Figure 1). This site operated during 1952 and, prior to remediation, was an open field covered with cobbles, with no vegetation growing on the surface. The southern half of the burial ground ran in a north-south direction, whereas the northern portion of the burial ground angled toward the east. The burial ground measured approximately $55.3 \mathrm{~m}(181 \mathrm{ft})$ by $15.2 \mathrm{~m}$ $(50 \mathrm{ft})$ by $4.5 \mathrm{~m}(15 \mathrm{ft})$ deep (DOE-RL 2001). The site received irradiated reactor parts that were removed during the conversion of the 105-F Reactor from the Liquid $3 X$ to the Ball $3 X$ Project safety systems. The burial ground received mostly vertical safety rod thimbles and step plugs. Prior to remediation, the dose rate at the surface of the burial ground was less than $1 \mathrm{millirad} / \mathrm{hr}$ (DOE-RL 2001).

\subsection{REMEDIAL ACTION FIELD ACTIVITIES}

\subsection{EXCAVATION AND DISPOSAL}

Remedial action at the 118-F-3 site began on January 31, 2006 with load out of waste material completed on May 23, 2006. Excavation of the site involved removing metal and concrete debris including piping, sheet metal, an empty tank structure, a large heat-transfer tower, thimbles, and step plugs. No asbestos-containing material was identified during waste excavation. At the conclusion of excavation activities, the remediation footprint was

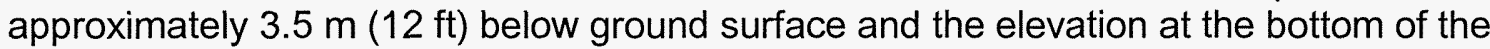
excavation was $121.5 \mathrm{~m}(400 \mathrm{ft})$ above sea level. An estimated 4,060 metric tons $(4,476$ U.S. tons) of material from the site was disposed of at ERDF. In addition, approximately 1,400 cubic meters (49,441 cubic feet) of clean overburden material was excavated from the 118-F-3 waste site and stockpiled for potential reuse as backfill. All contaminated materials removed from the 118-F-3 waste site were disposed of at ERDF. Pre- and post-remediation topographic maps are shown in Figures 2 and 3, respectively. Photographs of the remediation activities are provided in Figures 4 through 6. 
Figure 1. Hanford Site Map and 118-F-3 Site Plan.

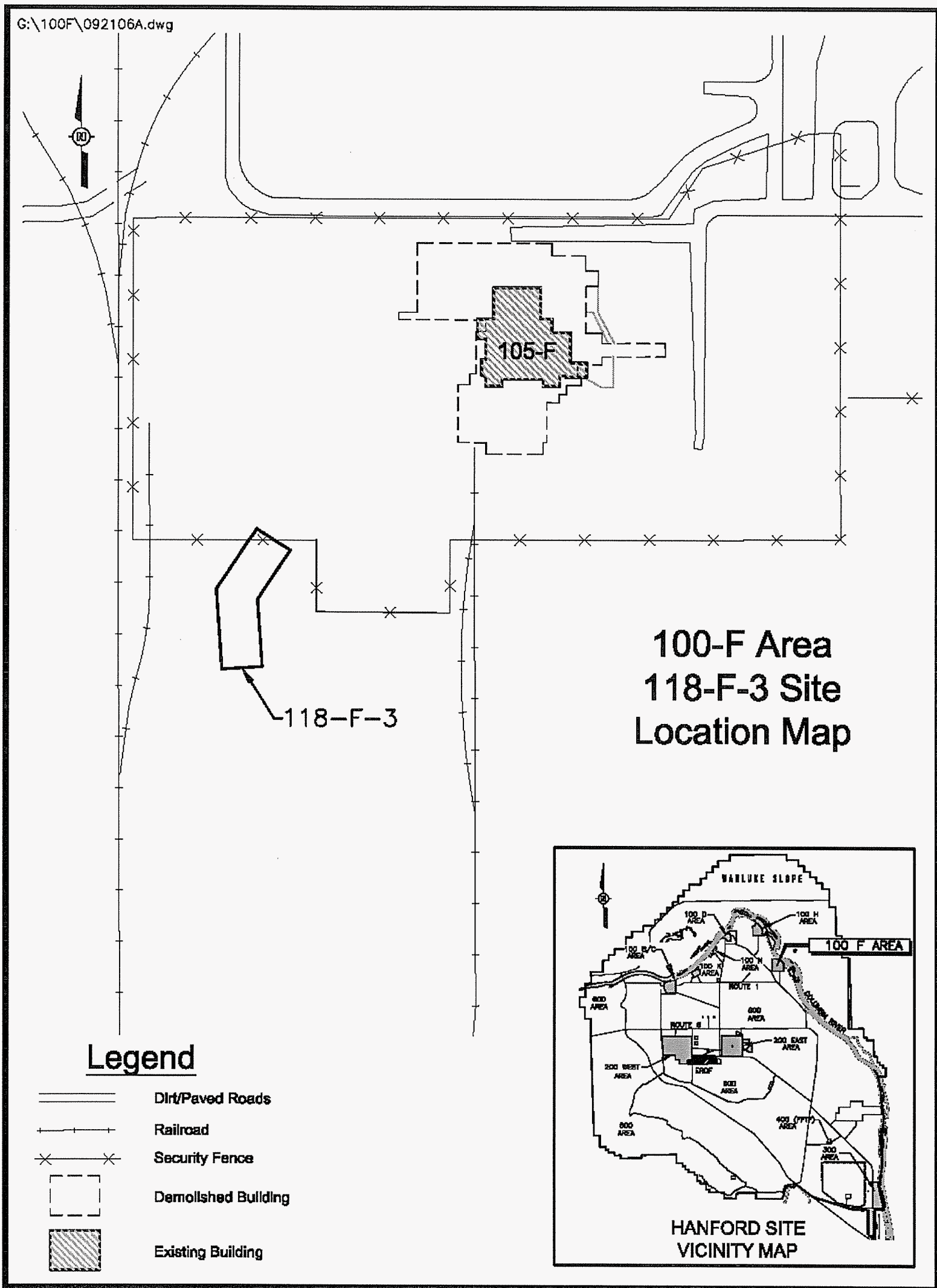


Figure 2. 118-F-3 Pre-Remediation Topographic Map.

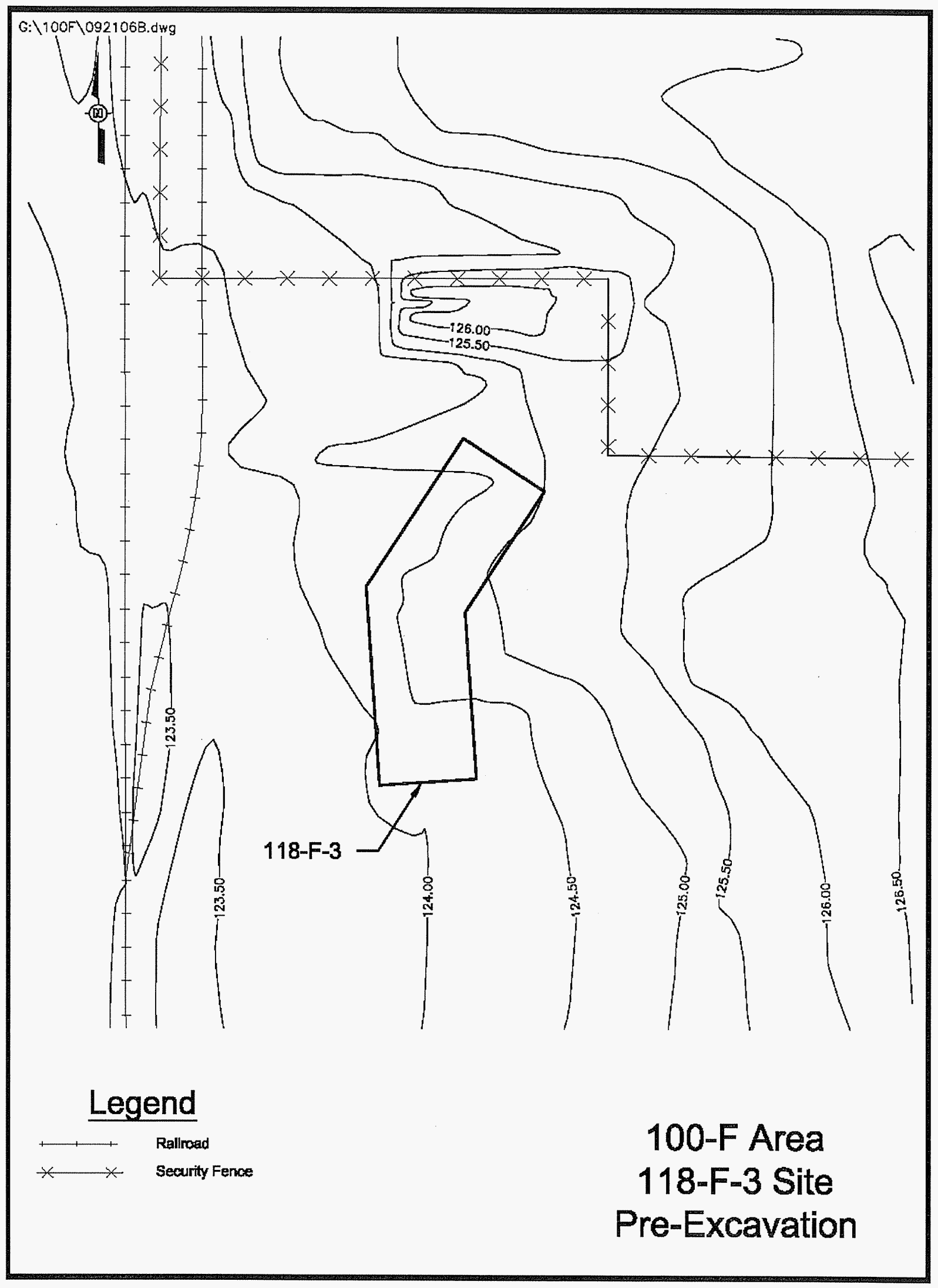


Figure 3. 118-F-3 Post-Remediation Topographic Map Showing Black Surface Ash and Focused Sample Location.

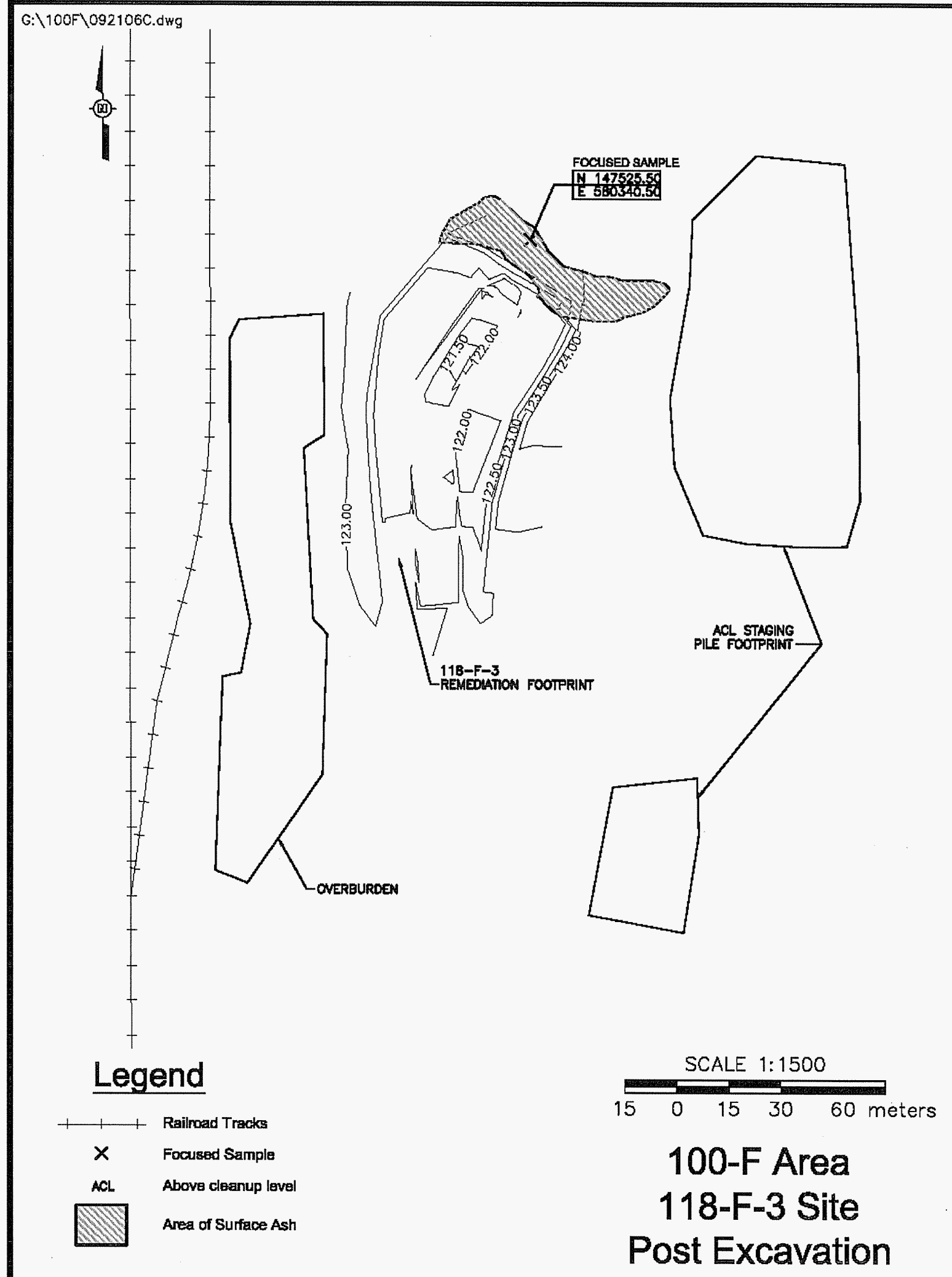


Figure 4. Photograph of 118-F-3 Burial Ground Remediation Debris.

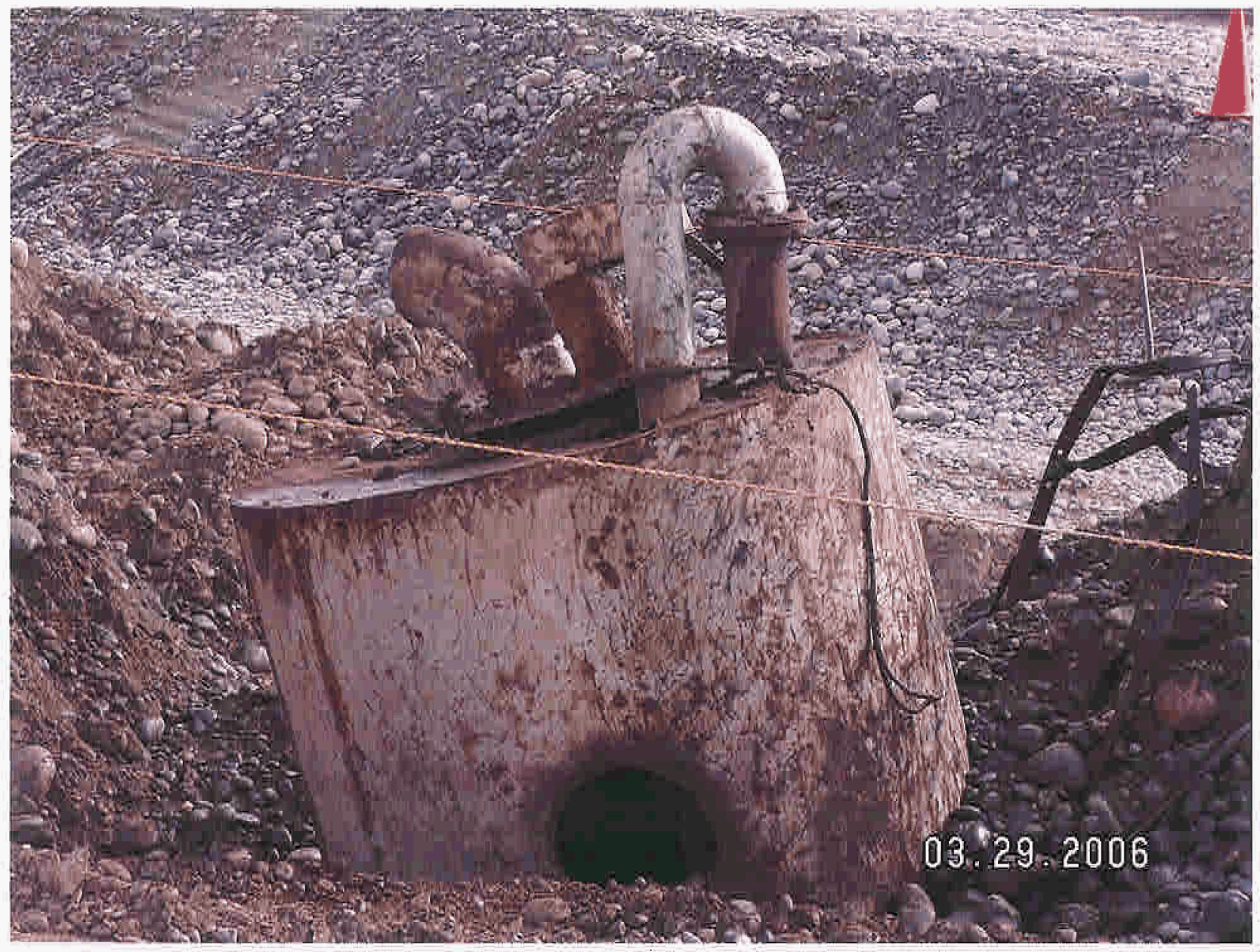


Figure 5. Photograph of 118-F-3 Burial Ground Remediation Debris.

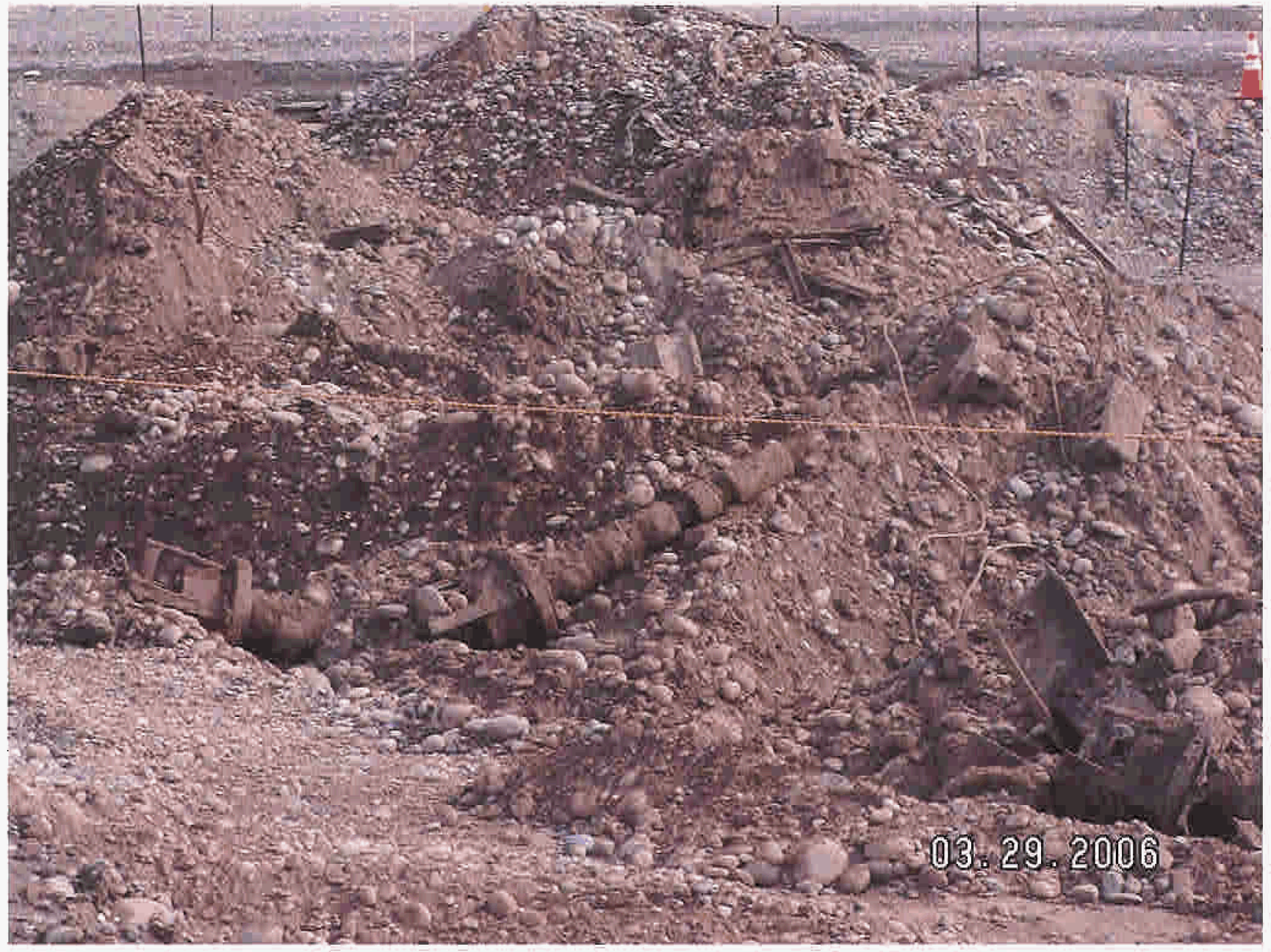


Figure 6. Photograph of 118-F-3 Remediation Footprint.

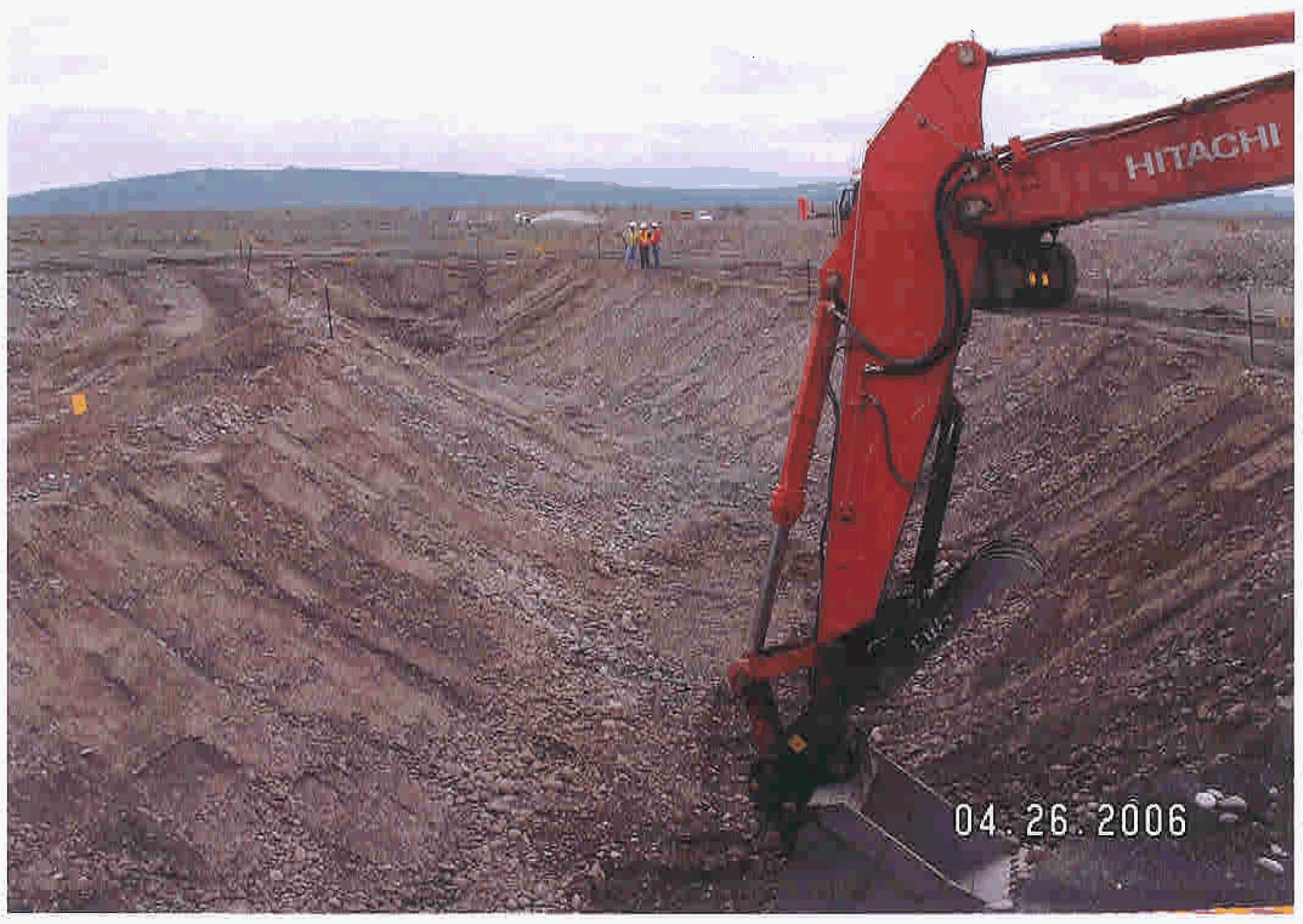




\subsection{FIELD SCREENING}

In-process characterization samples were analyzed for the COCs identified in the 100 Area Burial Grounds Remedial Action Sampling and Analysis Plan (SAP) (DOE-RL 2001) along with a wide range of metals, semi-volatile organic compounds, gamma energy emitting isotopes, gross alpha, and gross beta. In addition, samples were collected from an area containing a black surface ash located at the northern end of the 118-F-3 excavation. Strontium-90 and barium were detected at levels above soil background concentrations in the black surface ash and boron exceeded the ecological screening criteria. Based on the surface ash sample results, all verification samples were analyzed for strontium-90, barium, and boron in addition to the listed waste site COCs.

Radiological field screening was conducted during the site remedial action effort to provide an initial assessment of the attainment of radiological cleanup levels. Field screening at the site included using a Global Positioning Environmental Radiological Surveyor (GPERS) to quickly assess the presence and level of contamination. The radiological survey, conducted May 3 , 2006 , detected areas of residual radiological contamination that required additional site excavation (Figure 7). The "hot spot" areas were further excavated and an activated metal wire was located and removed along with the underlying soil. A second GPERS survey was performed on May 15, 2006 in order to demonstrate that the subsequent remediation efforts had removed the residual radiological contamination and that no further remediation was required at the site (Figure 8). The second GPERS survey detected an area of elevated radiation levels in the southern portion of the burial ground (Figure 8). Additional hand held surveys were performed over the area and no elevated radionuclides were detected. Therefore, no further excavation was required in this area prior to collection of the verification samples. 


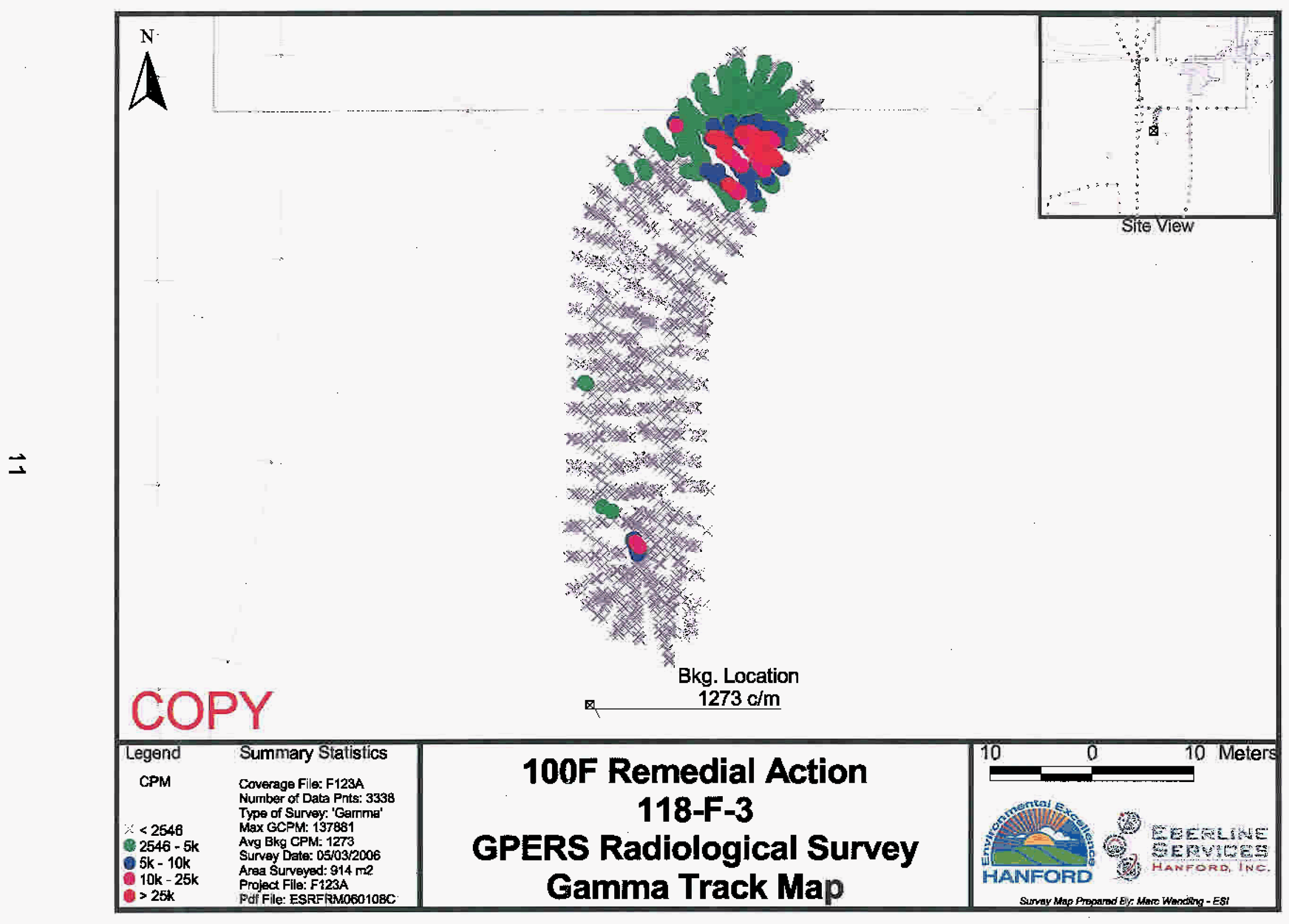

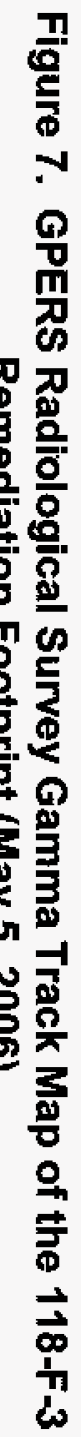




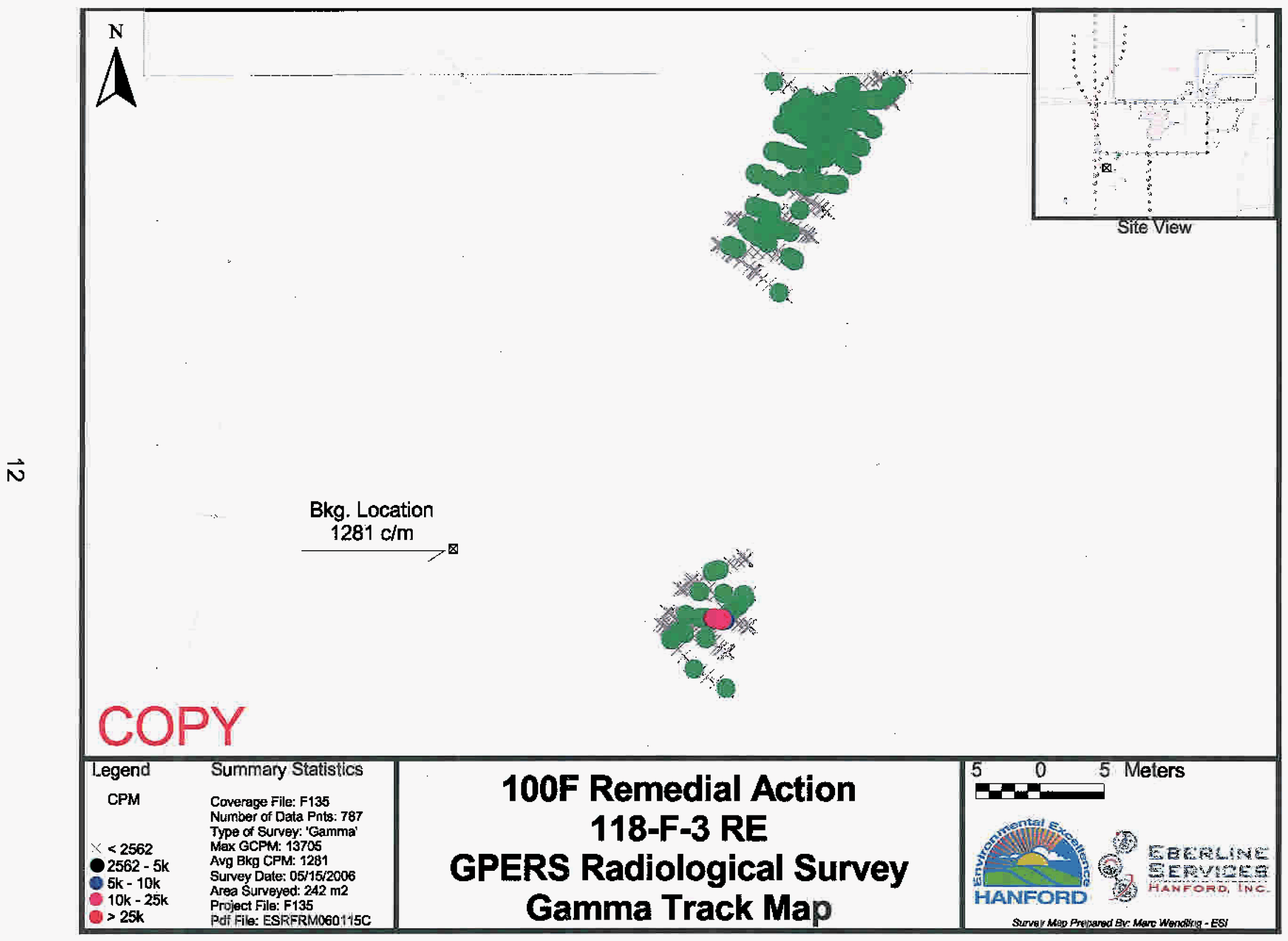

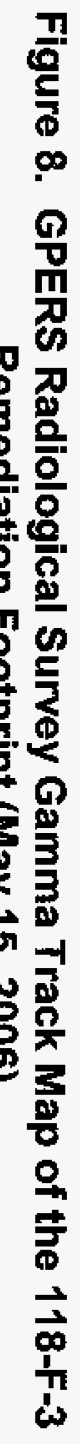




\subsection{FOCUSED SAMPLING AND ANALYSIS}

A focused sample was collected from the area of black surface ash located to the immediate north of the 118-F-3 waste site (Figures 3 and 9). The surface ash covers an area of approximately 130 square meters (1,400 square feet). On August 3,2005 , a focused sample and regulatory split were collected of the black surface ash. These samples were analyzed for the listed COCs. In addition, the regulatory split was analyzed for ICP metals, polychlorinated biphenyls, gross alpha and gross beta. No PCBs were detected in the EPA split sample, and the gross alpha and gross beta results were below their respective trigger limits of $15 \mathrm{pCi} / \mathrm{g}$ and $23 \mathrm{pCi} / \mathrm{g}$. Therefore, no further analysis was required. The results of the focused sampling for the waste site COCs are discussed further in Section 5.0 of this cleanup verification package.

\subsection{CLEANUP VERIFICATION SAMPLING AND ANALYSIS}

Final cleanup verification samples were collected in August of 2006 to confirm acceptability of residual contaminant concentrations in the soil at the $118-\mathrm{F}-3$ waste site. The verification samples were submitted to offsite laboratories for analysis using approved EPA analytical methods, as required per the 100 Area Burial Grounds Remedial Action Sampling and Analysis Plan (DOE-RL 2001). The 118-F-3 site was excavated to a depth of approximately $3.5 \mathrm{~m}$ (12 $\mathrm{ft})$. The 118-F-3 remediation excavation footprint was classified as one shallow-zone decision unit based on its size and depth. The overburden (stockpiled soil) and the above-cleanup-level (ACL) staging pile footprint are separate decision units. As specified in the SAP (DOE-RL 2001), four composite samples and a duplicate were collected from each of the waste site decision units. Additionally, one regulatory split was collected per decision unit at the request of the EPA. The duplicate samples and regulatory splits were analyzed for ICP metals, polychlorinated biphenyls, gross alpha, and gross beta, in addition to the listed COCs. No PCBs were detected in the duplicate or EPA split samples and the gross alpha results were below the trigger limit of $15 \mathrm{pCi} / \mathrm{g}$, therefore, no further analysis was required. One EPA split sample (EPA-J134T9) was above the gross beta trigger limit $(23 \mathrm{pCi} / \mathrm{g})$ at $23.5 \mathrm{pCi} / \mathrm{g}$. Strontium-90, the primary beta emitter, was analyzed and reported below the limit of detection. The results of the statistical sampling for the waste site COCs (which includes strontium-90) are discussed further in Section 5.0 of this cleanup verification package.

Verification sampling was performed by dividing each decision unit (i.e., the excavation footprint, stockpiled soil, and ACL staging pile footprint) into four sampling areas (A1, A2, A3, and A4) with the sampling areas further divided into 16-node sample grids. One statistical verification sample was collected per sampling area by compositing soil collected at four randomly selected nodes. As such, each decision unit was represented by four composite statistical verification samples. The sample design methodology and sample location figures are presented in the verification sample design calculation brief in Appendix C. 
Figure 9. Photograph of Black Surface Ash Located at Northern End of Remediation Footprint.

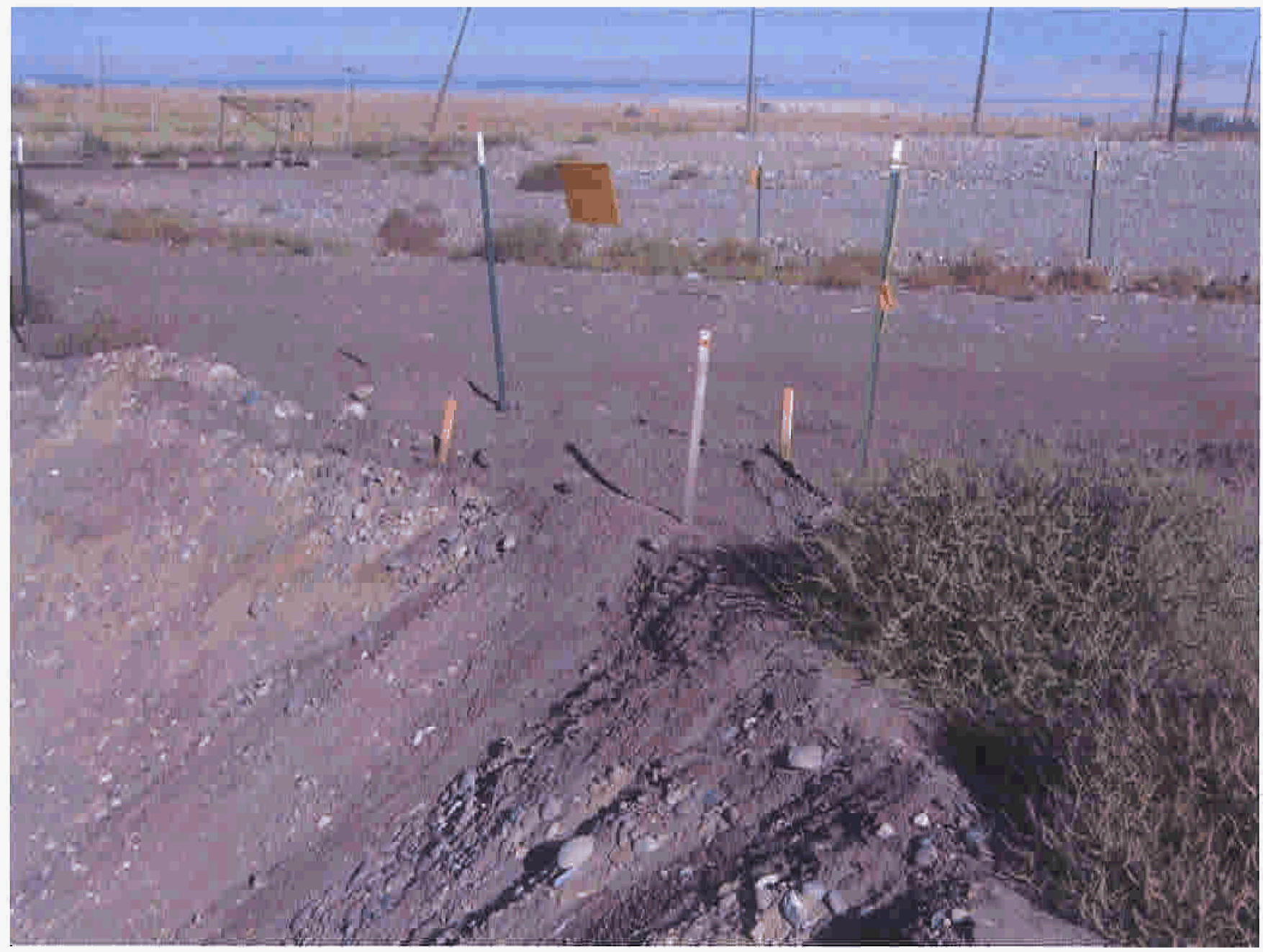




\subsection{CLEANUP VERIFICATION DATA EVALUATION}

This section presents the evaluation of the 118-F-3 cleanup verification data for comparison with the data quality criteria and RAGs.

\subsection{DATA QUALITY ASSESSMENT PROCESS}

A data quality assessment (DQA) was performed to compare the verification sampling approach and resulting analytical data with the sampling and data quality requirements specified by the project objectives and performance specifications.

The DQA for the 118-F-3 site determined that the data are of the right type, quality, and quantity to support site verification decisions within specified error tolerances. All analytical data were found to be acceptable for decision-making purposes. The evaluation verified that the sample design was sufficient for the purpose of clean site verification. The cleanup verification sample analytical data are stored in the Environmental Restoration project-specific database for data evaluation prior to being submitted for inclusion in the Hanford Environmental Information System database. The verification data are summarized in Appendix A. The detailed DQA is presented in Appendix B.

\subsection{CONTAMINANTS OF CONCERN 95\% UPPER CONFIDENCE LIMIT}

The primary statistical calculation to support cleanup verification is the $95 \%$ upper confidence limit (UCL) on the arithmetic mean of the data. The $95 \%$ UCL values for each COC are computed for each decision unit (e.g., for the shallow zone, overburden [stockpiled soil], and ACL staging pile footprint). Prior to calculating the $95 \% \mathrm{UCL}$, the individual sample results are reviewed and, as appropriate, adjusted per the SAP (DOE-RL 2001) and RDR/RAWP (DOE-RL 2005). This process is summarized below.

For radionuclides, the laboratory-reported value is used in the calculation of the $95 \% \mathrm{UCL}$. In cases where the laboratory does not report a value for data qualified with a "U" (i.e., less than the detection limit), one-half of the minimum detectable activity is used in the calculation of the $95 \%$ UCL. For nonradionuclides, a value equal to one-half the practical quantitation limit is used for data flagged with a "U" (i.e., less than the detection limit) in the calculation of the $95 \%$ UCL, as required by Washington Administrative Code (WAC) 173-340-740[7][g]. If greater than half of the sample results for a given nonradionuclide COC are below detection, the statistical value is set equal to the maximum concentration detected (i.e., versus computing a $95 \% \mathrm{UCL}$ ).

Verification sampling summary statistics (95\% UCL values) are listed in Table 2. Individual sample cleanup verification results are presented in Appendix A. The columns on the left side of Table 2 are the COCs and the $95 \%$ UCL values before subtraction of background. The fifth column of Table 2 presents the background, where values exist, and the last three columns present the statistical values adjusted for background, if appropriate, which becomes the cleanup verification data set used for further evaluation and modeling. 
Table 2. Cleanup Verification Data Set.

\begin{tabular}{|c|c|c|c|c|c|c|c|}
\hline \multirow[b]{2}{*}{ cocs } & \multicolumn{3}{|c|}{ 95\% UCL Statistical Values ${ }^{a}(\mathrm{pCi} / \mathrm{g})$} & \multirow{2}{*}{$\begin{array}{l}\text { Hanford Site } \\
\text { Background } \\
\text { (pCi/g) }\end{array}$} & \multicolumn{3}{|c|}{$\begin{array}{l}\text { Cleanup Verification Data Set } \\
\text { (pCi/g) }\end{array}$} \\
\hline & $\begin{array}{l}\text { Shallow } \\
\text { Zone }\end{array}$ & Overburden & $\begin{array}{c}\text { ACL } \\
\text { Staging } \\
\text { Pile } \\
\text { Footprint }\end{array}$ & & $\begin{array}{l}\text { Shallow } \\
\text { Zone }\end{array}$ & Overburden & $\begin{array}{c}\text { ACL } \\
\text { Staging } \\
\text { Pile } \\
\text { Footprint }\end{array}$ \\
\hline Cobalt-60 & 0.378 & 0.150 (ND) & 0.299 & 0.008 & 0.378 & 0.142 (ND) & 0.299 \\
\hline Cesium-137 & 0.144 & 0.050 (ND) & 0.170 & 1.1 & 0.144 & $\begin{array}{l}0(<\mathrm{BG}) \\
(\mathrm{ND})\end{array}$ & 0.170 \\
\hline Nickel-63 & 16.5 & $\begin{array}{l}0.801 \\
(\mathrm{ND})\end{array}$ & 13.4 & N/A & 16.5 & $\begin{array}{l}0.801 \\
(\mathrm{ND})\end{array}$ & 13.4 \\
\hline Strontium-90 & 0.235 & 0.082 (ND) & $\begin{array}{l}0.045 \\
\text { (ND) }\end{array}$ & 0.18 & 0.235 & $\begin{array}{c}0(<\mathrm{BG}) \\
(\mathrm{ND})\end{array}$ & 0.045 (ND) \\
\hline \multirow[b]{2}{*}{ cocs } & \multicolumn{3}{|c|}{$95 \%$ UCL Statistical Values ${ }^{a}(\mathrm{mg} / \mathrm{kg})$} & \multirow[b]{2}{*}{$\begin{array}{l}\text { Hanford Site } \\
\text { Background } \\
(\mathrm{mg} / \mathrm{kg})\end{array}$} & \multicolumn{3}{|c|}{$\begin{array}{c}\text { Cleanup Verification Data Set } \\
(\mathrm{mg} / \mathrm{kg})\end{array}$} \\
\hline & $\begin{array}{l}\text { Shallow } \\
\text { Zone }\end{array}$ & Overburden & $\begin{array}{c}\text { ACL } \\
\text { Staging } \\
\text { Pile } \\
\text { Footprint }\end{array}$ & & $\begin{array}{l}\text { Shallow } \\
\text { Zone }\end{array}$ & Overburden & $\begin{array}{c}\text { ACL } \\
\text { Staging } \\
\text { Pile } \\
\text { Footprint }\end{array}$ \\
\hline Barium & 104 & 70.6 & 99.7 & 132 & 104 & 70.6 & 99.7 \\
\hline Boron & 10.4 & 2.4 & 5.4 & N/A & 10.4 & 2.4 & 5.4 \\
\hline
\end{tabular}

${ }^{a}$ The shallow zone, ACL staging pile footprint, and BCL overburden are from the 118-F-3 Cleanup Verification $95 \%$ UCL Calculations, Calculation No. 0100F-CA-V0273, Rev. 0. Refer to Appendix C for additional details on determination of statistical values.

${ }^{b}$ Represents the 90 th percentile of the lognormal distribution (DOE-RL 1996).

${ }^{c}$ For overburden the anthropogenic background (DOE-RL 1996) and naturally occurring background is subtracted from all radionuclides. For other decision units (shallow zone and ACL staging pile footprint), only naturally occurring background (uranium) is subtracted. Refer to the 95\% UCL calculation brief in Appendix $\mathrm{C}$ for additional details on determination of statistical values.

$\mathrm{ACL}=$ above cleanup level

$\mathrm{BG}=$ background

COCs = contaminants of concern

$\mathrm{BCL}=$ below cleanup level
$\mathrm{N} / \mathrm{A}=$ not applicable

$\mathrm{ND}=$ not detected (in all samples in the data set)

$\mathrm{UCL}=$ upper confidence limit

\subsection{FOCUSED SAMPLE RESULTS}

One focused sample was collected from the area of black surface ash located to the immediate north of the 118-F-3 waste site and analyzed for the site COCs. Statistical analysis (e.g., calculation of a $95 \%$ UCL value) is inappropriate to use for evaluation of the focused sample; therefore, the sample results are evaluated using a direct comparison of the detected values to the cleanup levels. Table 3 provides a comparison of the focused sample results against the cleanup criteria. 
Table 3. Comparison of Focused Sample Results to Remedial Action Goals.

\begin{tabular}{|c|c|c|c|c|c|c|}
\hline \multirow[b]{2}{*}{ cocs } & \multirow[b]{2}{*}{$\begin{array}{l}\text { Maximum } \\
\text { Result } \\
\text { (pCi/g) }\end{array}$} & \multicolumn{3}{|c|}{ Generic Site Lookup Values ${ }^{a}(\mathrm{pCi} / \mathrm{g})$} & \multirow[b]{2}{*}{$\begin{array}{l}\text { Does the } \\
\text { Maximum } \\
\text { Result } \\
\text { Exceed } \\
\text { Lookup } \\
\text { values? }\end{array}$} & \multirow[b]{2}{*}{$\begin{array}{l}\text { Does the } \\
\text { Maximum } \\
\text { Result Pass } \\
\text { Modeling? }\end{array}$} \\
\hline & & $\begin{array}{l}\text { Shallow } \\
\text { Zone } \\
\text { Lookup } \\
\text { Value }^{b}\end{array}$ & $\begin{array}{c}\text { Soil } \\
\text { Concentration } \\
\text { for } \\
\text { Groundwater } \\
\text { Protection }\end{array}$ & $\begin{array}{c}\text { Soil } \\
\text { Concentration } \\
\text { for River } \\
\text { Protection }\end{array}$ & & \\
\hline Cesium-137 & 0.180 (ND) & 6.2 & $1,465^{\mathrm{c}}$ & $1,465^{\mathrm{C}}$ & No & N/A \\
\hline Cobalt-60 & 0.180 (ND) & 1.4 & $13,900^{c}$ & $13,900^{c}$ & No & N/A \\
\hline Nickel-63 & 4.05 (ND) & $4,013^{\mathrm{c}}$ & $83^{\mathrm{c}}$ & $83^{c}$ & No & N/A \\
\hline Strontium-90 & 0.217 (ND) & 4.5 & $27.6^{c}$ & $27.6^{\mathrm{C}}$ & No & N/A \\
\hline \multirow[b]{2}{*}{ cocs } & \multirow[b]{2}{*}{$\begin{array}{c}\text { Maximum } \\
\text { Result } \\
(\mathrm{mg} / \mathrm{kg})\end{array}$} & \multicolumn{3}{|c|}{ Remedial Action Goals ${ }^{\mathrm{a}}$ (mg/kg) } & \multirow[b]{2}{*}{$\begin{array}{l}\text { Does the } \\
\text { Maximum } \\
\text { Result } \\
\text { Exceed } \\
\text { RAGs? }\end{array}$} & \multirow[b]{2}{*}{$\begin{array}{c}\text { Does the } \\
\text { Maximum } \\
\text { Result Pass } \\
\text { Modeling? }\end{array}$} \\
\hline & & $\begin{array}{c}\text { Direct } \\
\text { Exposure }\end{array}$ & $\begin{array}{c}\text { Soil } \\
\text { Concentration } \\
\text { for } \\
\text { Groundwater } \\
\text { Protection }\end{array}$ & $\begin{array}{c}\text { Soil } \\
\text { Concentration } \\
\text { for River } \\
\text { Protection }\end{array}$ & & \\
\hline Barium & 902 & $5,600^{d}$ & $132^{\mathrm{e}, \mathrm{f}}$ & $224^{\mathrm{g}}$ & Yes & Yes $^{\text {h }}$ \\
\hline Boron $^{i}$ & 150 & 16,000 & 320 & $-\ldots$ & No & N/A \\
\hline
\end{tabular}

a Lookup values and RAGs obtained from the 100 Area RDR/RAWP (DOE-RL 2005) or calculated per WAC 173-340-720,

WAC 173-340-730, and WAC 173-340-740, Method B, 1996, unless otherwise noted.

b Activity corresponding to a single-radionuclide $15 \mathrm{mrem} / \mathrm{yr}$ exposure as calculated using a generic RESRAD model (DOE-RL 2005).

c Revised lookup value per 100 Area Radionuclide and Nonradionuclide Lookup Values for the 1995 Interim Remedial Action Record of Decision (BHI 2004).

d Noncarcinogenic cleanup level calculated from WAC 173-340-740(3), 1996 (Method B for soils) (as presented in the 100 Area RDR/RAWP [DOE-RL 2005]). Updated oral reference dose values (as provided in IRIS) yield Method B direct exposure RAG values of $16,000 \mathrm{mg} / \mathrm{kg}$ and $120,000 \mathrm{mg} / \mathrm{kg}$ for barium and chromium, respectively.

e Where cleanup levels are less than background, cleanup levels default to background (WAC 173-340-700[4][d]) (1996).

f Barium soil cleanup level for groundwater protection calculated from WAC 173-340-740(3)(a)(ii)(A), 1996 ("100 times rule") and WAC 173-340-720(3), 1996 (Method B for groundwater) is $112 \mathrm{mg} / \mathrm{kg}$ (as presented in the 100 Area RDR/RAWP [DOE-RL 2005]). The updated oral reference dose value (as provided in IRIS) yields a Method B groundwater cleanup criteria of $7 \mathrm{mg} / \mathrm{L}$, as compared to the more restrictive MCL of $2 \mathrm{mg} / \mathrm{L}$ (40 CFR 141). Per WAC 173-340-740(3)(a)(ii)(A), 1996 ("100 times rule"), the most restrictive updated soil cleanup level for groundwater protection would be $200 \mathrm{mg} / \mathrm{kg}$.

9 Barium soil cleanup level for river protection calculated from WAC 173-340-740(3)(a)(ii)(A), 1996 ("100 times rule"), a DAF of 2, and WAC 173-340-720(3), 1996 (Method B for groundwater) is $224 \mathrm{mg} / \mathrm{kg}$ (as presented in the 100 Area RDR/RAWP [DOE-RL 2005]). No surface water bioconcentration factor is available for barium and no ambient water quality criteria exists separate from the previous drinking water standard; therefore, no WAC 173-340-730(3), 1996 (Method B for surface waters) value can be determined.

h Based on 100 Area Analogous Sites RESRAD Calculations (BHI 2005), and a $\mathrm{K}_{d}$ (distribution coefficient) value of $25 \mathrm{~mL} / \mathrm{g}$, barium is not expected to migrate more than $3 \mathrm{~m}$ (10 ft) vertically in 1,000 years (BHI 2005).

i No Hanford Site-specific or Washington State background value available.

i No cleanup level is available from the Ecology Cleanup Levels and Risk Calculations database (Ecology 2005), and no bioconcentration factor or AWQC values are available to calculate cleanup levels (WAC 173-340-730(3)(a)(iii), 1996 [Method B for surface waters]).

AWQC = ambient water quality criteria

CFR $\quad=$ Code of Federal Regulations

$\mathrm{COC}=$ contaminant of concern

$\mathrm{DAF} \quad=$ dilution attenuation factor

IRIS = Integrated Risk Information System

MCL = maximum contaminant level

N/A = not applicable

ND $\quad=$ not detected

RAG = remedial action goal

RESRAD = RESidual RADioactivity (dose model)

RDR/RAWP = remedial design report/remedial action work plan

WAC = Washington Administrative Code 


\subsection{RESRAD MODELING}

A site-specific RESidual RADioactivity (RESRAD) model was not developed for the 118-F-3 waste site. The radionuclide statistical sampling results, shown in Table 2, meet the remedial action goals summarized in Table 1 as demonstrated using the sum-of-fractions method in section 5.1.1, below. Additionally, no radionuclides were detected in the focused soil sample, as shown in Table 3.

\subsection{EVALUATION OF REMEDIAL ACTION GOAL ATTAINMENT}

This section demonstrates that remedial actions at the 118-F-3 site have achieved the applicable RAGs. Sections 5.1, 5.2, and 5.3 address attainment of direct exposure RAGs, groundwater protection RAGs, and Columbia River protection RAGs, respectively. Section 5.4 documents application of the WAC 173-340 three-part test to the shallow zone, overburden (stockpiled soil), and the ACL staging pile footprint. This test is required for nonradionuclide COCs only and is based on the most restrictive RAG for each zone.

\subsection{DIRECT EXPOSURE SOIL REMEDIAL ACTION GOALS ATTAINED}

\subsubsection{Radionuclides}

The cumulative radionuclide dose was calculated separately for the shallow zone remediation footprint (Table 4) and ACL staging pile footprint (Table 5), using the sum-of-fractions method. The columns on the left side of Tables 4 and 5 are the COCs and the $95 \%$ UCL values. The third column of each table presents the single radionuclide $15 \mathrm{mrem} / \mathrm{yr}$ dose-equivalence activity, and the last column presents the statistical values divided by the dose-equivalence activity. The cumulative dose of $5.2 \mathrm{mrem} / \mathrm{yr}$ for the shallow zone remediation footprint is less than the $15 \mathrm{mrem} / \mathrm{yr}$ RAG. The cumulative dose of $3.6 \mathrm{mrem} / \mathrm{yr}$ for the ACL staging pile footprint is also less than the $15 \mathrm{mrem} / \mathrm{yr}$ RAG. Therefore, both the shallow zone decision unit and $A C L$ staging pile footprint achieve the remedial action goals.

The statistical values for the overburden (stockpiled soil) radionuclide COCs were not detected and, therefore, the radionuclide direct exposure RAGs have been met. Similarly, no radionuclide COCs were detected in the focused sample collected from black surface ash located at the northern end of the 118-F-3 excavation. All applicable radionuclide RAGs have been met for direct exposure at the 118-F-3 waste site. 
Table 4. Attainment of Radionuclide Direct Exposure RAG for the Shallow Zone Remediation Footprint.

\begin{tabular}{|c|c|c|c|}
\hline $\begin{array}{l}\text { Contaminants of } \\
\text { Potential Concern }\end{array}$ & $\begin{array}{l}95 \% \text { UCL Value } \\
\text { (pCi/g) }\end{array}$ & $\begin{array}{l}\text { Activity Equivalent } \\
\text { to } 15 \mathrm{mrem} / \mathrm{yr} \\
\text { Dose }(\mathrm{pCi} / \mathrm{g})\end{array}$ & Fraction \\
\hline Cobalt-60 & 0.378 & 1.4 & 0.27 \\
\hline Cesium-137 & 0.144 & 6.2 & 0.023 \\
\hline Nickel-63 & 16.5 & 4,013 & 0.0041 \\
\hline Strontium-90 & 0.235 & 4.5 & 0.052 \\
\hline \multirow{2}{*}{\multicolumn{3}{|c|}{$\begin{array}{r}\text { Sum of Fractions } \\
\text { Equivalent Dose (mrem/yr) }\end{array}$}} & 0.35 \\
\hline & & & 5.2 \\
\hline
\end{tabular}

Table 5. Attainment of Radionuclide Direct Exposure RAG for the ACL Staging Pile Footprint.

\begin{tabular}{|c|c|c|c|}
\hline $\begin{array}{l}\text { Contaminants of } \\
\text { Potential Concern }\end{array}$ & $\begin{array}{l}95 \% \text { UCL Value } \\
\text { (pCi/g) }\end{array}$ & $\begin{array}{l}\text { Activity Equivalent } \\
\text { to } 15 \mathrm{mrem} / \mathrm{yr} \\
\text { Dose }(\mathrm{pCi} / \mathrm{g})\end{array}$ & Fraction \\
\hline Cobalt-60 & 0.299 & 1.4 & 0.21 \\
\hline Cesium-137 & 0.170 & 6.2 & 0.027 \\
\hline Nickel-63 & 13.4 & 4,013 & 0.0033 \\
\hline \multicolumn{3}{|r|}{ Sum of Fractions } & 0.24 \\
\hline \multicolumn{3}{|c|}{ Equivalent Dose (mrem/yr) } & 3.6 \\
\hline
\end{tabular}

\subsubsection{Nonradionuclides}

5.1.2.1 Direct Comparison to RAGs. Table 6 compares the cleanup verification statistical values presented in Tables 2 and 3 to the direct exposure RAGs presented in Table 1. All residual concentrations are below the direct exposure RAG and, as such, all applicable nonradionuclide RAGs have been met for direct exposure.

Table 6. Attainment of Nonradionuclide Direct Exposure Standards. (2 pages)

\begin{tabular}{|c|c|c|c|}
\hline Nonradionuclides & $\begin{array}{c}\text { Cleanup Verification } \\
\text { Data Set (mg/kg) }\end{array}$ & $\begin{array}{c}\text { Direct Exposure RAG } \\
\text { (mg/kg) }\end{array}$ & $\begin{array}{c}\text { Direct Exposure RAGs } \\
\text { Attained? }^{\mathrm{b}}\end{array}$ \\
\hline \multicolumn{3}{|c|}{ Shallow Zone } \\
\hline Barium $^{\mid}$ & 104 & $5,600^{\mathrm{c}}$ & Yes \\
\hline Boron $^{\mathrm{d}}$ & 10.4 & 16,000 & Yes \\
\hline
\end{tabular}


Table 6. Attainment of Nonradionuclide Direct Exposure Standards. (2 pages)

\begin{tabular}{|c|c|c|c|}
\hline Nonradionuclides & $\begin{array}{l}\text { Cleanup Verification } \\
\text { Data Set }(\mathrm{mg} / \mathrm{kg})\end{array}$ & $\begin{array}{c}\text { Direct Exposure } \mathrm{RAG}^{\mathrm{a}} \\
(\mathrm{mg} / \mathrm{kg})\end{array}$ & $\begin{array}{c}\text { Direct Exposure RAGs } \\
\text { Attained? }^{\mathrm{b}}\end{array}$ \\
\hline \multicolumn{4}{|c|}{ Overburden } \\
\hline Barium & 70.6 & $5,600^{c}$ & Yes \\
\hline Boron $^{d}$ & 2.4 & 16,000 & Yes \\
\hline \multicolumn{4}{|c|}{ ACL Staging Pile Footprint } \\
\hline Barium & 99.7 & $5,600^{c}$ & Yes \\
\hline Boron $^{d}$ & 5.4 & 16,000 & Yes \\
\hline \multicolumn{4}{|c|}{ Focused Sample } \\
\hline Barium & 902 & $5,600^{\mathrm{C}}$ & Yes \\
\hline Boron $^{d}$ & 150 & 16,000 & Yes \\
\hline \multicolumn{4}{|c|}{$\begin{array}{l}\text { Lookup values and RAGs obtained from the } 100 \text { Area RDR/RAWP (DOE-RL 2005) or calculated per WAC 173-340-720, } \\
\text { WAC 173-340-730, and WAC 173-340-740, Method B, 1996, unless otherwise noted. } \\
\text { Criterion is comparison to the cleanup criteria (RAG). } \\
\text { Noncarcinogenic cleanup level calculated from WAC 173-340-740(3), } 1996 \text { (Method B for soils) (as presented in the } 100 \text { Area } \\
\text { RDR/RAWP [DOE-RL 2005]). Updated oral reference dose values (as provided in IRIS) yield Method B direct exposure RAG } \\
\text { values of } 16,000 \mathrm{mg} / \mathrm{kg} \text { and } 120,000 \mathrm{mg} / \mathrm{kg} \text { for barium and chromium, respectively. } \\
\text { No Hanford Site-specific or Washington State background value available. }\end{array}$} \\
\hline \multicolumn{4}{|c|}{$\begin{array}{ll}\text { ACL } & =\text { above cleanup level } \\
\text { IRIS } & =\text { Integrated Risk Information System } \\
\text { RAG } & =\text { remedial action goal } \\
\text { RDR/RAWP } & \text { remedial design reportremedial action work plan } \\
\text { WAC } & =\text { Washington Administrative Code }\end{array}$} \\
\hline
\end{tabular}

5.1.2.2 Noncarcinogenic Hazard Quotient RAG Attained. For noncarcinogenic COCs, WAC 173-340-740(5)(a) and (b) specify the evaluation of the hazard quotient, which is given as the daily intake divided by a reference dose (DOE-RL 2005). This evaluation is shown for the 118-F-3 shallow zone, overburden (stockpiled soil) and ACL staging pile footprint in the $95 \%$ UCL calculation brief (Appendix C). Barium was detected below background in all three decision units, and as such was not included in the hazard quotient calculation. Because there is no established background value for boron, an individual hazard quotient was calculated for this COC. The calculated individual hazard quotient for residual concentrations of boron was less than 1.0 for all three decision units, therefore, the noncarcinogenic hazard quotient RAG has been attained for the 118-F-3 waste site.

5.1.2.3 Carcinogenic Risk RAG Attained. For individual nonradionuclide carcinogenic COCs, the WAC 173-340 Method B cleanup limits are based on an incremental cancer risk of $1 \times 10^{-6}$. For nonradionuclide carcinogenic COCs, the total excess cancer risk must be less than $1 \times 10^{-5}$ (DOE-RL 2005). There are no carcinogenic nonradionuclide COCs for $118-\mathrm{F}-3$, therefore calculation of the carcinogenic risk is not required. 


\subsection{GROUNDWATER REMEDIAL ACTION GOALS ATTAINED}

\subsubsection{Radionuclides}

Cesium-137, cobalt-60, nickel-63, and strontium-90 were detected in the verification samples for the 118-F-3 shallow zone remediation footprint and cobalt-60, cesium-137, and nickel-63 were detected in the verification samples for the ACL staging pile footprint. Based on 100 Area Radionuclide and Nonradionuclide Lookup Values for the 1995 Remedial Action Record of Decision (BHI 2004), the residual concentrations of the radionuclide COCs in soil are significantly less than the concentrations predicted to cause the $4 \mathrm{mrem} / \mathrm{yr}$ drinking water standard (DOE-RL 2005) to be exceeded. RESRAD modeling in BHI 2004, using $\mathrm{K}_{d}$ (distribution coefficient) values of $50 \mathrm{~mL} / \mathrm{g}$ for cesium-137 and cobalt-60, $30 \mathrm{~mL} / \mathrm{g}$ for nickel-63, and $25 \mathrm{~mL} / \mathrm{g}$ for strontium-90, predicts that the residual soil concentrations of these radionuclides at 118-F-3 will be protective of groundwater (and therefore, the Columbia River) at the maximum contaminant level (MCL) that meets the $4 \mathrm{mrem} / \mathrm{yr}$ drinking water standard (DOE-RL 2005). As such, the groundwater RAGs have been attained for the shallow zone and ACL staging pile footprint decision units at the 118-F-3 waste site.

No radionuclide COCs were detected in the overburden (stockpiled soil) or the focused sample of the black surface ash, thus achieving the groundwater RAGs for radionuclides.

\subsubsection{Nonradionuclides}

Table 7 illustrates the comparison of cleanup verification values to the soil RAGs for groundwater protection. The statistical values for barium and boron meet the soil RAGs for groundwater protection in the shallow zone, overburden (stockpiled soil) and ACL staging pile footprint. The regulatory split collected from sampling area A3 of the remediation footprint exceeded the groundwater protection RAG for barium at a concentration of $155 \mathrm{mg} / \mathrm{kg}$ (Appendix C). The regulatory split sample was within the $35 \%$ acceptability criteria for relative percent difference between the primary sample and the regulatory split.

The table shows that residual concentrations of barium in the focused sample exceeded the soil RAGs for groundwater protection. Additionally, the regulatory split of the ash sample exceeded the groundwater soil protection RAGs for copper and selenium at $32.9 \mathrm{mg} / \mathrm{kg}$ and $1.5 \mathrm{mg} / \mathrm{kg}$, respectively (Appendix $\mathrm{C}$ ). In the primary sample, copper was detected below background and selenium was undetected (Appendix C). None of these constituents (barium, copper, or selenium) are expected to reach groundwater based on their soil partitioning coefficients. Data were not collected on the vertical extent of residual contamination, but given the soil-partitioning coefficients of barium $(25 \mathrm{~mL} / \mathrm{g})$, copper $(22 \mathrm{~mL} / \mathrm{g})$, and selenium $(150 \mathrm{~mL} / \mathrm{g})$ the results of the 100 Area Analogous Sites RESRAD Calculations (BHI 2005) indicate that these constituents will not reach groundwater (and therefore, the Columbia River) in 1,000 years given a clean zone extending at least $3 \mathrm{~m}(10 \mathrm{ft})$. 
Table 7. Attainment of Nonradionuclide Remedial Action Goals for Protection of Groundwater and the Columbia River. (1 page)

\begin{tabular}{|c|c|c|c|c|c|}
\hline Nonradionuclides & $\begin{array}{l}\text { Cleanup } \\
\text { Verification } \\
\text { Data Set } \\
\text { (mg/kg) }\end{array}$ & $\begin{array}{l}\text { Soil RAG for } \\
\text { Groundwater } \\
\text { Protection }^{\mathrm{a}} \\
(\mathrm{mg} / \mathrm{kg})\end{array}$ & $\begin{array}{l}\text { Soil RAG for } \\
\text { Columbia River } \\
\text { Protection }^{\mathrm{a}} \\
(\mathrm{mg} / \mathrm{kg})\end{array}$ & $\begin{array}{c}\text { Groundwater } \\
\text { and/or River } \\
\text { Protection } \\
\text { RAGs } \\
\text { Exceeded? }\end{array}$ & $\begin{array}{l}\text { Does the } \\
\text { Maximum } \\
\text { Result Pass } \\
\text { Modeling? }\end{array}$ \\
\hline \multicolumn{6}{|c|}{ Shallow Zone } \\
\hline Barium & 104 & $132^{b, c}$ & $224^{d}$ & No & N/A \\
\hline Boron $^{e}$ & 10.4 & 320 & $--^{f}$ & No & N/A \\
\hline \multicolumn{6}{|c|}{ Overburden } \\
\hline Barium & 70.6 & $132^{b, c}$ & $224^{d}$ & No & N/A \\
\hline Boron $^{e}$ & 2.4 & 320 & $--^{f}$ & No & N/A \\
\hline \multicolumn{6}{|c|}{ ACL Staging Pile Footprint } \\
\hline Barium & 99.7 & $132^{b, c}$ & $224^{d}$ & No & N/A \\
\hline Boron $^{e}$ & 5.4 & 320 & $--^{f}$ & No & N/A \\
\hline \multicolumn{6}{|c|}{ Focused Sample } \\
\hline Barium & 902 & $132^{b, c}$ & $224^{d}$ & Yes & $Y_{e s}{ }^{g}$ \\
\hline Boron $^{e}$ & 150 & 320 & $--^{f}$ & No & $N / A$ \\
\hline
\end{tabular}

a Lookup values and RAGs obtained from the 100 Area RDR/RAWP (DOE-RL 2005) or calculated per WAC 173-340-720, WAC 173-340-730, and WAC 173-340-740, Method B, 1996, unless otherwise noted.

b Where cleanup levels are less than background, cleanup levels default to background (WAC 173-340-700[4][d]) (1996).

c Barium soil cleanup level for groundwater protection calculated from WAC 173-340-740(3)(a)(ii)(A), 1996 ("100 times rule") and WAC 173-340-720(3), 1996 (Method B for groundwater) is $112 \mathrm{mg} / \mathrm{kg}$ (as presented in the 100 Area RDR/RAWP

[DOE-RL 2005]). The updated oral reference dose value (as provided in IRIS) yields a Method $B$ groundwater cleanup criteria of $7 \mathrm{mg} / \mathrm{L}$, as compared to the more restrictive MCL of $2 \mathrm{mg} / \mathrm{L}$ (40 CFR 141). Per WAC 173-340-740(3)(a)(ii)(A), 1996 ("100 times rule"), the most restrictive updated soil cleanup level for groundwater protection would be $200 \mathrm{mg} / \mathrm{kg}$.

d Barium soil cleanup level for river protection calculated from WAC 173-340-740(3)(a)(ii)(A), 1996 ("100 times rule"), a DAF of 2 and WAC 173-340-720(3), 1996 (Method B for groundwater) is $224 \mathrm{mg} / \mathrm{kg}$ (as presented in the 100 Area RDR/RAWP [DOE-RL 2005]). No surface water bioconcentration factor is available for barium and no ambient water quality criteria exists separate from the previous drinking water standard; therefore, no WAC 173-340-730(3), 1996 (Method B for surface waters) value can be determined.

e No Hanford Site-specific or Washington State background value available.

f No cleanup level is available from the Ecology Cleanup Levels and Risk Calculations database (Ecology 2005), and no bioconcentration factor or AWQC values are available to calculate cleanup levels (WAC 173-340-730(3)(a)(iii), 1996 [Method B for surface waters]).

9 Based on 100 Area Analogous Sites RESRAD Calculations (BHI 2005), and a $\mathrm{K}_{d}$ (distribution coefficient) value of $25 \mathrm{~mL} / \mathrm{g}$, barium is not expected to migrate more than $3 \mathrm{~m}$ (10 ft) vertically in 1,000 years $(\mathrm{BHI} 2005)$.

AWQC = ambient water quality criteria

$\mathrm{ACL} \quad=$ above cleanup level

NV $\quad=$ no value

CFR = Code of Federal Regulations

RAG = remedial action goal

$\mathrm{DAF} \quad=$ dilution attenuation factor

IRIS = Integrated Risk Information System $\quad$ WAC Washington Administrative Code

RESRAD = RESidual RADioactivity (dose model)

$\mathrm{MCL} \quad=$ maximum contaminant level

N/A = Not applicable. RESRAD modeling was not performed because residual concentrations meet the groundwater and river protection RAGs. 


\subsection{COLUMBIA RIVER REMEDIAL ACTION GOALS ATTAINED}

\subsubsection{Radionuclides}

The river protection RAGs for radionuclides are identical to the groundwater protection RAGs. The results indicated that radionuclides are not predicted to reach groundwater (and, by extension, not predicted to reach the Columbia River) at levels that would cause the $4 \mathrm{mrem} / \mathrm{yr}$ drinking water standard (DOE-RL 2005) to be exceeded. Therefore, the Columbia River protection RAGs have been attained.

\subsubsection{Nonradionuclides}

Table 7 illustrates the comparison of cleanup verification statistical values to the soil RAGs for protection of the Columbia River. The statistical values for barium and boron meet the soil RAGs for river protection in the shallow zone, overburden (stockpiled soil), and ACL staging pile footprint (Table 7). The regulatory split collected from sampling area A3 of the remediation footprint exceeded the groundwater protection RAG for barium at a concentration of $155 \mathrm{mg} / \mathrm{kg}$ (Appendix C). The regulatory split sample was within the $35 \%$ acceptability criteria for relative percent difference between the primary sample and the regulatory split.

Table 7 shows that residual concentrations of barium in the focused sample exceeded the soil RAGs for groundwater protection. Additionally, the regulatory split for the focused sample exceeded the copper $(39.2 \mathrm{mg} / \mathrm{kg}$ ) and selenium $(1.5 \mathrm{mg} / \mathrm{kg})$ soil RAGs for river protection. Data were not collected on the vertical extent of residual contamination but given the soil-partitioning coefficients of barium $(25 \mathrm{~mL} / \mathrm{g})$, copper $(22 \mathrm{~mL} / \mathrm{g})$, and selenium $(150 \mathrm{~mL} / \mathrm{g})$ the results of the 100 Area Analogous Sites RESRAD Calculations (BHI 2005) indicate that these constituents will not reach groundwater (and therefore, the Columbia River) in 1,000 years given a clean zone extending at least $3 \mathrm{~m}(9.8 \mathrm{ft})$.

\subsection{WAC 173-340 THREE-PART TEST FOR NONRADIONUCLIDES}

Sections $5.1,5.2$, and 5.3 look separately at compliance with direct exposure RAGs, groundwater protection soil RAGs, and Columbia River protection soil RAGs. Section 5.4 documents application of the WAC 173-340 three-part test for nonradionuclides using the most restrictive RAGs applicable to each decision unit (i.e., shallow zone, overburden [stockpiled soil], and ACL staging pile footprint). The most restrictive RAG is defined as the lowest of the direct exposure, groundwater protection, and river protection RAGs. The direct exposure, groundwater protection, and river protection RAGs are applicable to the shallow zone, overburden [stockpiled soil], and ACL staging pile footprint. The WAC 173-340 three-part test consists of the following criteria: (1) the cleanup verification statistical value must be less than the cleanup level, (2) no single detection can exceed two times the cleanup criteria, and (3) the percentage of samples exceeding the cleanup criteria must be less than $10 \%$.

Table 8 summarizes the results of the WAC 173-340 three-part test (WAC 173-340-740[7]) for the shallow zone, overburden (stockpiled soil), and ACL staging pile footprint sample data sets. For barium and boron, the table lists the most restrictive applicable RAG (selected from the RAGs in Table 1), the maximum detected value, the total number of samples collected, and the number of samples exceeding the most restrictive RAG. The final column of the table describes the result of 
applying the three WAC $173-340$ criteria using the values listed in the preceding columns. Table 8 shows that barium and boron pass the WAC 173-340 three-part test for all data sets.

Table 8. Application of the WAC 173-340 Three-Part Test. (1 Page)

\begin{tabular}{|c|c|c|c|c|c|c|}
\hline Nonradionuclides & $\begin{array}{c}\text { Most } \\
\text { Stringent } \\
\text { Applicable } \\
\text { RAG } \\
\text { (mg/kg) }\end{array}$ & $\begin{array}{c}\text { Statistical } \\
\text { Value } \\
(\mathrm{mg} / \mathrm{kg})^{\mathrm{a}}\end{array}$ & $\begin{array}{c}\text { Maximum } \\
\text { Detected } \\
\text { Value } \\
(\mathrm{mg} / \mathrm{kg})^{\mathbf{b}}\end{array}$ & $\begin{array}{c}\text { Total } \\
\text { Number } \\
\text { of } \\
\text { Samples }^{c}\end{array}$ & $\begin{array}{l}\text { Number } \\
\text { Exceeding }_{\text {Criteria }^{d}}\end{array}$ & $\begin{array}{l}\text { RAGs } \\
\text { Attained? } \\
\text { (Yes/No) }\end{array}$ \\
\hline \multicolumn{7}{|c|}{ Shallow Zone } \\
\hline Barium & $132^{\mathrm{e}, \mathrm{f}}$ & 104 & 116 & 5 & 0 & Yes \\
\hline Boron $^{9}$ & 320 & 10.4 & 12.7 & 5 & 0 & Yes \\
\hline \multicolumn{7}{|c|}{ Overburden } \\
\hline Barium & $132^{\mathrm{e}, \mathrm{f}}$ & 70.6 & 73.2 & 5 & 0 & Yes \\
\hline Boron $^{9}$ & 320 & 2.31 & 2.6 & 5 & 0 & Yes \\
\hline \multicolumn{7}{|c|}{ ACL Staging Pile Footprint } \\
\hline Barium & $132^{\mathrm{e}, \mathrm{f}}$ & 98.4 & 98.3 & 5 & 0 & Yes \\
\hline Boron $^{9}$ & 320 & 5.5 & 6.6 & 5 & 0 & Yes \\
\hline
\end{tabular}

a Criterion is comparison to the cleanup criteria (RAG).

b Criterion is no single detection can exceed two times the cleanup criteria.

c The total number of samples includes field duplicate samples, which are included in the evaluation as separate samples.

d Criterion is the percentage of samples exceeding the cleanup criteria must be less than $10 \%$.

e Where cleanup levels are less than background, cleanup levels default to background (WAC 173-340-700[4][d]) (1996).

f Barium soil cleanup level for groundwater protection calculated from WAC 173-340-740(3)(a)(ii)(A), 1996 ("100 times rule") and WAC 173-340-720(3), 1996 (Method B for groundwater) is $112 \mathrm{mg} / \mathrm{kg}$ (as presented in the 100 Area RDR/RAWP [DOE-RL 2005]). The updated oral reference dose value (as provided in IRIS) yields a Method $B$ groundwater cleanup criteria of $7 \mathrm{mg} / \mathrm{L}$, as compared to the more restrictive MCL of $2 \mathrm{mg} / \mathrm{L}$ (40 CFR 141). Per WAC 173-340-740(3)(a)(ii)(A), 1996 ("100 times rule"), the most restrictive updated soil cleanup level for groundwater protection would be $200 \mathrm{mg} / \mathrm{kg}$.

9 No Hanford Site-specific or Washington State background value available.

$\mathrm{ACL} \quad=$ above cleanup level RAG = remedial action goal

IRIS = Integrated Risk Information System $\quad$ RDR/RAWP = remedial design report/remedial action work plan

$\mathrm{MCL}=$ maximum contaminant level

WAC $=$ Washington Administrative Code

\subsection{STATEMENT OF PROTECTIVENESS}

This cleanup verification package demonstrates that remedial action at the 118-F-3 site has achieved the remedial action objectives and corresponding RAGs established in the ROD (EPA 2000) and RDR/RAWP (DOE-RL 2005). The contaminated materials from the site have been excavated and disposed of at the ERDF. The remaining soils at the 118-F-3 site have been sampled, analyzed, and evaluated. The results of this effort indicate that residual concentrations will support future land uses that can be represented (or bounded) by a ruralresidential scenario and that residual concentrations throughout the site pose no threat to groundwater or the Columbia River. This site has no deep zone; therefore, no institutional controls are required. The 118-F-3 site is verified to be remediated in accordance with the ROD (EPA 2000) and may be backfilled. 


\subsection{REFERENCES}

40 CFR 141, "National Primary Drinking Water Regulations," Code of Federal Regulations, as amended.

65 FR 76708, "National Primary Drinking Water Regulations; Radionuclides; Final Rule," Federal Register, Vol. 65, No. 236, p. 76708, December 7, 2000.

BHI, 2001, Calculation of Total Uranium Activity Corresponding to a Maximum Contaminant Level for Total Uranium of 30 Micrograms per Liter in Groundwater, 0100X-CA-V0038, Rev. 0, Bechtel Hanford, Inc., Richland, Washington.

BHI, 2004, 100 Area Radionuclide and Nonradionuclide Lookup Values for the 1995 Interim Remedial Action Record of Decision, 0100X-CA-V0046, Rev. 0, Bechtel Hanford, Inc., Richland, Washington

BHI, 2005, 100 Area Analogous Sites RESRAD Calculations, 0100X-CA-V0050, Rev. 0, Bechtel Hanford, Inc., Richland, Washington.

DOE Order 5400.5, Radiation Protection of the Public and the Environment, U.S. Department of Energy, Washington, D.C.

DOE-RL, 1996, Hanford Site Background: Part 2, Soil Background for Radionuclides, DOE RL-96-12, Rev. 0, Richland, U.S. Department of Energy, Richland Operations Office, Richland, Washington.

DOE-RL, 1998, Tri-Party Agreement Handbook Management Procedures, RL-TPA-90-0001, Guideline Number TPA-MP-14, "Maintenance of the Waste Information Data System (WIDS)," U.S. Department of Energy, Richland Operations Office, Richland, Washington.

DOE-RL, 2001, 100 Area Burial Grounds Remedial Action Sampling and Analysis Plan, DOE/RL-2001-35, Rev. 0, U.S. Department of Energy, Richland Operations Office, Richland, Washington.

DOE-RL, 2005, Remedial Design Report/Remedial Action Work Plan for the 100 Area, DOE/RL-96-17, Rev. 5, U.S. Department of Energy, Richland Operations Office, Richland, Washington.

Ecology, EPA, and DOE, 1989, Hanford Federal Facility Agreement and Consent Order, 2 vols., as amended, Washington State Department of Ecology, U.S. Environmental Protection Agency, and U.S. Department of Energy, Olympia, Washington.

Ecology, 2005, Cleanup Levels and Risk Calculations (CLARC) Database, Washington State Department of Ecology, Olympia, Washington, <https://fortress.wa.gov/ecy/clarc/CLARCHome.aspx>. 
EPA, 2000, Record of Decision for the 100-BC-1, 100-BC-2, 100-DR-1, 100-DR-2, 100-FR-2, 100-HR-2, and 100-KR-2 Operable Units, Hanford Site (100 Area Burial Grounds),

Benton County, Washington, U.S. Environmental Protection Agency, Region 10, Seattle, Washington.

WAC 173-340, 1996, "Model Toxics Control Act - Cleanup," Washington Administrative Code. 


\section{APPENDIX A}

SUMMARY OF VERIFICATION SOIL SAMPLING RESULTS FOR THE 118-F-3 WASTE SITE COCs 
CVP-2006-00008

Rev.0 
118-F-3 Shallow Zone Verification Sampling Results (3 Pages).

\begin{tabular}{|c|c|c|c|c|c|c|c|c|c|c|c|c|c|c|}
\hline \multirow{2}{*}{$\begin{array}{c}\text { Sample } \\
\text { Location }\end{array}$} & \multirow{2}{*}{$\begin{array}{c}\text { Sample } \\
\text { Number }\end{array}$} & \multirow{2}{*}{$\begin{array}{c}\text { Sample } \\
\text { Date }\end{array}$} & \multicolumn{3}{|c|}{ Cesium-137 } & \multicolumn{3}{|c|}{ Cobalt-60 } & \multicolumn{3}{|c|}{ Nickel-63 } & \multicolumn{3}{|c|}{ Strontium-90 } \\
\hline & & & $\mathrm{pCi} / \mathrm{g}$ & $\mathbf{Q}$ & MDA & $\mathrm{pCi} / \mathrm{g}$ & $\mathbf{Q}$ & MDA & $\mathrm{pCi} / \mathrm{g}$ & $\mathbf{Q}$ & MDA & $\mathrm{pCi} / \mathrm{g}$ & $\mathbf{Q}$ & MDA \\
\hline $\mathrm{A} 1$ & J134T6 & $8 / 3 / 06$ & 0.121 & & 0.090 & 0.120 & $\bar{U}$ & 0.120 & 3.78 & & 3.40 & 0.177 & $\bar{U}$ & 0.210 \\
\hline $\mathrm{A} 2$ & J134T9 & $8 / 2 / 06$ & 0.110 & $\mathrm{U}$ & 0.110 & 0.140 & $\mathrm{U}$ & 0.140 & 4.21 & & 3.20 & 0.276 & $\mathrm{U}$ & 0.440 \\
\hline $\mathrm{A} 3$ & J134T 8 & $8 / 3 / 06$ & 0.200 & $\mathrm{U}$ & 0.200 & 0.378 & & 0.057 & 23.7 & & 4.20 & 0.276 & & 0.240 \\
\hline $\mathrm{A} 4$ & J134T7 & $8 / 3 / 06$ & 0.160 & & 0.049 & 0.042 & $\overline{\mathrm{U}}$ & 0.042 & -0.764 & $\mathrm{U}$ & 3.60 & 0.028 & $\mathrm{U}$ & 0.210 \\
\hline $\begin{array}{c}\text { Duplicate of } \\
\text { J134T9 }\end{array}$ & J134V0 & $8 / 2 / 06$ & 0.094 & & 0.069 & 0.093 & U & 0.093 & 2.06 & $\mathrm{U}$ & 3.30 & -0.045 & U & 0.390 \\
\hline Split of J134T9 & $\mathrm{J} 134 \mathrm{~V} 1$ & $8 / 2 / 06$ & 0.020 & & 0.0176 & 0.0199 & $\mathrm{U}$ & 0.0254 & 6.93 & & 6.00 & 0.00411 & $U$ & 0.202 \\
\hline $\begin{array}{c}\text { Black Ash } \\
\text { Focused } \\
\text { Sample }\end{array}$ & J134Y0 & $8 / 3 / 06$ & 0.180 & U & 0.180 & 0.180 & $\mathrm{U}$ & 0.180 & 4.05 & U & 4.70 & 0.127 & $\mathrm{U}$ & 0.210 \\
\hline $\begin{array}{c}\text { EPA Split of } \\
\text { J134T9 }\end{array}$ & EPA-J134T9 & $8 / 2 / 06$ & 0.017 & & NR & 0.026 & & NR & & & & -0.166 & & 1.70 \\
\hline $\begin{array}{c}\text { EPA Split of } \\
\mathrm{J} 134 \mathrm{~T} 8\end{array}$ & EPA-J134T8 & $8 / 3 / 06$ & 0.029 & & NR & 0.43 & & NR & & & & -0.388 & & 2.00 \\
\hline $\begin{array}{c}\text { EPA Split of } \\
\text { J134Y0 }\end{array}$ & EPA-J134Y0 & $8 / 3 / 06$ & 0.38 & & NR & 0.02 & & NR & & & & -0.087 & & 1.70 \\
\hline
\end{tabular}

\begin{tabular}{|c|c|c|c|c|c|c|c|c|}
\hline \multirow{2}{*}{$\begin{array}{c}\text { Sample } \\
\text { Location }\end{array}$} & \multirow{2}{*}{$\begin{array}{c}\text { Sample } \\
\text { Number }\end{array}$} & \multirow{2}{*}{$\begin{array}{c}\text { Sample } \\
\text { Date }\end{array}$} & \multicolumn{3}{|c|}{ Barium } & \multicolumn{3}{|c|}{ Boron } \\
\hline & & & $\mathrm{mg} / \mathrm{kg}$ & $\mathbf{Q}$ & PQL & $\mathrm{mg} / \mathrm{kg}$ & $\mathbf{Q}$ & PQL \\
\hline $\mathrm{A} 1$ & $\mathrm{~J} 134 \mathrm{~T} 6$ & $8 / 3 / 06$ & 89.4 & $\mathrm{C}$ & 0.060 & 7.8 & & 0.70 \\
\hline $\mathrm{A} 2$ & J134T9 & $8 / 2 / 06$ & 52.3 & $\mathrm{C}$ & 0.060 & 0.81 & & 0.70 \\
\hline $\mathrm{A} 3$ & J134T8 & $8 / 3 / 06$ & 12.7 & & 0.060 & 116 & $\mathrm{C}$ & 0.70 \\
\hline $\mathrm{A} 4$ & $\mathrm{~J} 134 \mathrm{~T} 7$ & $8 / 3 / 06$ & 66.1 & C & 0.060 & 1.9 & & 0.69 \\
\hline $\begin{array}{c}\text { Duplicate of } \\
\text { J134T9 }\end{array}$ & J134V0 & $8 / 2 / 06$ & 49.0 & $\mathrm{C}$ & 0.060 & 1.2 & & 0.70 \\
\hline Split of J134T9 & J134V1 & $8 / 2 / 06$ & 59.0 & & 0.51 & 3.3 & $\mathrm{BC}$ & 1.5 \\
\hline $\begin{array}{c}\text { Black Ash } \\
\text { Focused } \\
\text { Sample }\end{array}$ & J134Y0 & $8 / 3 / 06$ & 902 & & 0.060 & 150 & $\mathrm{C}$ & 0.73 \\
\hline $\begin{array}{l}\text { EPA Split of } \\
\text { J134T9 }\end{array}$ & EPA-J134T9 & $8 / 2 / 06$ & 120 & & 0.090 & & & \\
\hline $\begin{array}{c}\text { EPA Split of } \\
\text { J134T8 }\end{array}$ & EPA-J134T8 & $8 / 3 / 06$ & 155 & & 0.090 & & & \\
\hline $\begin{array}{c}\text { EPA Split of } \\
\text { J134Y0 }\end{array}$ & EPA-J134Y0 & $8 / 3 / 06$ & 1160 & & 0.35 & & & \\
\hline
\end{tabular}

Note: The following abbreviations apply to all Appendix A tables.

Note: Data qualified with $\mathrm{N}, \mathrm{C}$ and $\mathrm{J}$ are considered acceptable values.

$\mathrm{NR}=$ not reported

$\mathrm{ACL}=$ above cleanup levels

$\mathrm{C}=$ analyte found in method blank

$\mathrm{PQL}=$ practical quantitation limit

$\mathrm{Q}=$ qualifier

$\mathrm{U}=$ undetected

$\mathrm{J}=$ estimated

$\mathrm{MDA}=$ minimum detectable activity

$\mathrm{N}=$ Spiked analyte recovery is outside stated control limits. 
118-F-3 Overburden Verification Sampling Results (3 Pages).

\begin{tabular}{|c|c|c|c|c|c|c|c|c|c|c|c|c|c|c|c|c|}
\hline \multirow{2}{*}{$\begin{array}{c}\text { Sample } \\
\text { Location }\end{array}$} & \multirow{2}{*}{$\begin{array}{c}\text { Sample } \\
\text { Number }\end{array}$} & \multirow{2}{*}{$\begin{array}{c}\text { Sample } \\
\text { Date }\end{array}$} & \multicolumn{2}{|c|}{ Cesi/g } & Q & MDA & pCi/g & Q & MDA & pCi/g & Q & MDA & pCi/g & Q & MDA \\
\hline A1 & $\mathrm{J} 134 \mathrm{Y} 1$ & $8 / 7 / 06$ & 0.120 & $\mathrm{U}$ & 0.120 & 0.150 & $\mathrm{U}$ & 0.150 & 1.12 & $\mathrm{U}$ & 2.50 & 0.078 & $\mathrm{U}$ & 0.210 \\
\hline $\mathrm{A} 2$ & $\mathrm{~J} 134 \mathrm{Y} 2$ & $8 / 9 / 06$ & 0.041 & $\mathrm{U}$ & 0.041 & 0.037 & $\mathrm{U}$ & 0.037 & -1.43 & $\mathrm{U}$ & 2.70 & 0.027 & $\mathrm{U}$ & 0.200 \\
\hline $\mathrm{A} 3$ & $\mathrm{~J} 134 \mathrm{Y} 4$ & $8 / 7 / 06$ & 0.035 & $\mathrm{U}$ & 0.035 & 0.041 & $\mathrm{U}$ & 0.041 & -0.083 & $\mathrm{U}$ & 2.50 & 0.064 & $\mathrm{U}$ & 0.250 \\
\hline $\mathrm{A} 4$ & $\mathrm{~J} 134 \mathrm{Y} 5$ & $8 / 7 / 06$ & 0.092 & $\mathrm{U}$ & 0.092 & 0.110 & $\mathrm{U}$ & 0.110 & 0.623 & $\mathrm{U}$ & 2.70 & -0.013 & $\mathrm{U}$ & 0.220 \\
\hline $\begin{array}{c}\text { Duplicate of } \\
\text { J134Y2 }\end{array}$ & $\mathrm{J} 134 \mathrm{Y} 3$ & $8 / 9 / 06$ & 0.044 & $\mathrm{U}$ & 0.044 & 0.045 & $\mathrm{U}$ & 0.045 & -2.44 & $\mathrm{U}$ & 2.90 & -0.100 & $\mathrm{U}$ & 0.230 \\
\hline $\begin{array}{c}\text { Split of } \\
\text { J134Y2 }\end{array}$ & $\mathrm{J} 134 \mathrm{Y} 6$ & $8 / 9 / 06$ & 0.005 & $\mathrm{U}$ & 0.020 & -0.006 & $\mathrm{U}$ & 0.020 & 1.81 & $\mathrm{U}$ & 5.44 & 0.025 & $\mathrm{U}$ & 0.130 \\
\hline $\begin{array}{c}\text { EPA Split of } \\
\text { J134Y2 }\end{array}$ & EPA-J134Y2 & $8 / 9 / 06$ & 0.012 & & $\mathrm{NR}$ & 0.019 & $\mathrm{U}$ & 0.019 & & & & & -0.186 & $\mathrm{NR}$ \\
\hline
\end{tabular}

\begin{tabular}{|c|c|c|c|c|c|c|c|c|}
\hline \multirow{2}{*}{$\begin{array}{c}\text { Sample } \\
\text { Location }\end{array}$} & \multirow{2}{*}{$\begin{array}{l}\text { Sample } \\
\text { Number }\end{array}$} & \multirow{2}{*}{$\begin{array}{l}\text { Sample } \\
\text { Date }\end{array}$} & \multicolumn{3}{|c|}{ Barium } & \multicolumn{3}{|c|}{ Boron } \\
\hline & & & $\mathrm{mg} / \mathrm{kg}$ & $\mathbf{Q}$ & PQL & $\mathrm{mg} / \mathrm{kg}$ & $\mathbf{Q}$ & PQL \\
\hline $\mathrm{Al}$ & J134Y1 & $8 / 7 / 06$ & 65.8 & & 0.06 & 2.6 & & 0.69 \\
\hline $\mathrm{A} 2$ & J134Y2 & $8 / 9 / 06$ & 73.2 & $\mathrm{C}$ & 0.06 & 1.7 & & 0.69 \\
\hline$\overline{\mathrm{A} 3}$ & $\mathrm{~J} 134 \mathrm{Y} 4$ & $8 / 7 / 06$ & 45.6 & & 0.06 & 1.5 & & 0.68 \\
\hline $\mathrm{A} 4$ & J134Y5 & $8 / 7 / 06$ & 65.7 & & 0.06 & 1.5 & & 0.68 \\
\hline $\begin{array}{c}\text { Duplicate of } \\
\text { J134Y2 }\end{array}$ & $\mathrm{J} 134 \mathrm{Y} 3$ & $8 / 9 / 06$ & 65.8 & $\mathrm{C}$ & 0.06 & 2 & & 0.69 \\
\hline $\begin{array}{l}\text { Split of } \\
\text { J134Y2 }\end{array}$ & J134Y6 & $8 / 9 / 06$ & 64.7 & & 0.5 & 2.8 & B & 1.5 \\
\hline $\begin{array}{c}\text { EPA Split of } \\
\text { J134Y2 }\end{array}$ & EPA-J134Y2 & $8 / 9 / 06$ & 80.3 & & 0.020 & & & \\
\hline
\end{tabular}


118-F-3 ACL Staging Pile Footprint Verification Sampling Results (3 Pages).

\begin{tabular}{|c|c|c|c|c|c|c|c|c|c|c|c|c|c|c|}
\hline $\begin{array}{c}\text { Sample } \\
\text { Location }\end{array}$ & \multirow{2}{*}{$\begin{array}{c}\text { Sample } \\
\text { Number }\end{array}$} & \multirow{2}{*}{ Sample Date } & & \multicolumn{3}{|c|}{ Cesium-137 } & \multicolumn{3}{c|}{ Cobalt-60 } & \multicolumn{3}{|c|}{ Nickel-63 } & \multicolumn{3}{c|}{ Strontium-90 } \\
\hline A1 & $\mathrm{J} 13538$ & $8 / 10 / 06$ & 0.101 & & 0.085 & 0.378 & & 0.092 & 15.3 & & 2.80 & -0.002 & $\mathrm{U}$ & 0.150 \\
\hline $\mathrm{A} 2$ & $\mathrm{~J} 13539$ & $8 / 10 / 06$ & 0.103 & & 0.040 & 0.264 & & 0.046 & 12.0 & & 2.70 & -0.026 & $\mathrm{U}$ & 0.220 \\
\hline $\mathrm{A} 3$ & $\mathrm{~J} 13541$ & $8 / 7 / 06$ & 0.198 & & 0.057 & 0.126 & & 0.048 & 1.33 & $\mathrm{U}$ & 3.00 & 0.001 & $\mathrm{U}$ & 0.390 \\
\hline $\mathrm{A} 4$ & $\mathrm{~J} 13540$ & $8 / 10 / 06$ & 0.140 & $\mathrm{U}$ & 0.140 & 0.070 & $\mathrm{U}$ & 0.070 & 0.216 & $\mathrm{U}$ & 2.70 & 0.071 & $\mathrm{U}$ & 0.220 \\
\hline $\begin{array}{c}\text { Duplicate of } \\
\text { J13541 }\end{array}$ & $\mathrm{J} 13542$ & $8 / 9 / 06$ & 0.218 & & 0.044 & 0.233 & & 0.056 & 1.72 & $\mathrm{U}$ & 2.90 & -0.001 & $\mathrm{U}$ & 0.330 \\
\hline Split of J13541 & $\mathrm{J} 13543$ & $8 / 9 / 06$ & 0.097 & & 0.0169 & 0.088 & 0.017 & 8.75 & & 5.43 & 0.011 & $\mathrm{U}$ & 0.142 \\
\hline $\begin{array}{c}\text { EPA Split of } \\
\text { J13541 }\end{array}$ & EPA-J13541 & $8 / 9 / 06$ & 0.120 & & $\mathrm{NR}$ & 0.146 & $\mathrm{NR}$ & & & & -0.569 & 1.70 \\
\hline
\end{tabular}

\begin{tabular}{|c|c|c|c|c|c|c|c|c|}
\hline \multirow{2}{*}{$\begin{array}{c}\text { Sample } \\
\text { Location }\end{array}$} & \multirow{2}{*}{$\begin{array}{c}\text { Sample } \\
\text { Number }\end{array}$} & \multirow{2}{*}{ Sample Date } & \multicolumn{3}{|c|}{ Barium } & \multicolumn{3}{|c|}{ Boron } \\
\cline { 6 - 10 } & & $\mathbf{m g} / \mathbf{k g}$ & $\mathbf{Q}$ & $\mathbf{P Q L}$ & $\mathrm{mg} / \mathrm{kg}$ & $\mathbf{Q}$ & PQL \\
\hline $\mathrm{A} 1$ & $\mathrm{~J} 13538$ & $8 / 10 / 06$ & 98.1 & & 0.060 & 6.6 & & 0.67 \\
\hline $\mathrm{A} 2$ & $\mathrm{~J} 13539$ & $8 / 10 / 06$ & 90.6 & & 0.060 & 2.7 & & 0.67 \\
\hline $\mathrm{A} 3$ & $\mathrm{~J} 13541$ & $8 / 7 / 06$ & 91.3 & $\mathrm{C}$ & 0.060 & 3.5 & & 0.69 \\
\hline $\mathrm{A} 4$ & $\mathrm{~J} 13540$ & $8 / 10 / 06$ & 63.8 & & 0.060 & 0.67 & $\mathrm{U}$ & 0.67 \\
\hline $\begin{array}{c}\text { Duplicate of } \\
\mathrm{J} 13541\end{array}$ & $\mathrm{~J} 13542$ & $8 / 9 / 06$ & 98.3 & $\mathrm{C}$ & 0.060 & 3.6 & 0.68 \\
\hline Split of J13541 & $\mathrm{J} 13543$ & $8 / 9 / 06$ & 82.5 & & 0.500 & 5.7 & $\mathrm{~B}$ & 1.5 \\
\hline $\begin{array}{c}\text { EPA Split of } \\
\mathrm{J} 13541\end{array}$ & EPA-J13541 & $8 / 9 / 06$ & 102 & & 0.030 & & & \\
\hline
\end{tabular}


CVP-2006-00008

Rev.0

A-4 
CVP-2006-00008

Rev. 0

APPENDIX B

DATA QUALITY ASSESSMENT

B-i 
CVP-2006-00008

Rev. 0

B-ii 


\section{B1.0 DATA QUALITY ASSESSMENT FOR THE 118-F-3 MINOR CONSTRUCTION BURIAL GROUND}

\section{B1.1 OVERVIEW}

The data quality assessment (DQA) completes the data life cycle (i.e., planning, implementation, and assessment) that was initiated by the data quality objectives process. The DQA includes a review of the field logbook information (WCH 2006) to verify sample location, date, and time. It also involves a scientific and statistical evaluation of the data to determine if they are of the right type, quality, and quantity to support their intended use for closeout decisions (EPA 2000).

This DQA was performed in accordance with data quality objectives found in the 100 Area Burial Grounds Remedial Action Sampling and Analysis Plan (SAP) (DOE-RL 2001). The DQA is based on the guidelines presented in Guidance for Data Quality Assessment (EPA 2000). Statistical tests used in this DQA were performed as specified in the SAP and the Remedial Design Report/Remedial Action Work Plan for the 100 Area (DOE-RL 2005). Contaminants of concern (COCs) used for the 118-F-3 waste site are identified in the SAP (cobalt-60, nickel-63), as well as by results from in-process waste characterization samples (strontium-90, barium, boron). Environmental Protection Agency (EPA) regulatory split samples, project split samples, and the corresponding main samples were analyzed for a wider range of analytes than the $\mathrm{COC}$ list. Split comparisons and data quality evaluations are performed for all analytes that are present in both the main and split SDGs. No equipment blank was collected for this site.

Prior to performing statistical tests, the field logbook (WCH 2006), the sample design (Appendix $\mathrm{C}$ ), and sample analytical data are evaluated. A portion of the cleanup verification sample analytical data is validated for compliance requirements (DOE-RL 2001). An evaluation is performed to determine if the laboratory carried out all steps required by the SAP and the laboratory contract governing the conduct of analysis and reporting of the data. Data validation, in accordance with validation procedures specified in Data Validation Procedure for Chemical Analysis (BHI 2000a) and in Data Validation Procedure for Radiochemical Analysis (BHI 2000b), is performed as part of data evaluation. After validation and data evaluation, the appropriate statistical analyses are performed on the analytical data (Appendix $\mathrm{C}$ ) to determine statistical values, as appropriate, for each contaminant. The cleanup verification sample analytical data are stored in the Environmental Restoration project-specific database prior to being submitted for inclusion in the Hanford Environmental Information System database and are also summarized in Appendix A of this document. 


\section{B1.2 LABORATORY QUALITY MEASURES}

All verification samples are subject to laboratory-specific quality assurance (QA) requirements, including instrument procurement, maintenance, calibration, and operation. Additional laboratory quality control (QC) checks are performed, as appropriate, for the analytical method at a rate of 1 per sample delivery group (SDG), or 1 in 20 , whichever is more frequent. Laboratory internal QC checks include the following:

- Laboratory Contamination. Each analytical batch contains a laboratory (method) blank (material of similar composition as the samples with known/minimal concentrations of the analytes of interest) carried through the complete analytical process. The method blank is used to evaluate samples for false-positive results due to contamination at the laboratory.

- Analytical Accuracy. For most analyses, a known quantity of representative analytes of interest (matrix spike/matrix spike duplicate [MS/MSD]) are added to a separate aliquot of a sample from the analytical batch. The recovery percentage of the added MS is used to evaluate analytical accuracy. For analyses not amenable to MS techniques (e.g., gamma energy analysis) or where analytical recovery is corrected via internal standards (e.g., alpha spectral analyses), accuracy is evaluated from recovery of the QC reference sample (e.g., laboratory control sample (LCS) or blank spike sample).

- Analytical Precision. Separate aliquots removed from the same sample container (replicate samples) are analyzed for each analytical batch. The replicate sample results (evaluated as relative percent differences [RPDs]) are used to assess analytical precision. However, natural heterogeneities in the soil matrix also add to the RPD calculation.

- QC Reference Samples. A QC reference sample is prepared from an independent standard at a concentration other than that used for calibration but within the calibration range. Reference samples provide an independent check on analytical technique and methodology.

Laboratories are also subject to periodic and random assessments of the laboratory performance, systems, and overall program. These assessments are performed by the Washington Closure Hanford QA group to ensure that the laboratories are performing within laboratory contract requirements.

\section{B1.3 DATA VALIDATION}

After sampling and analysis was completed, all of the fixed-base laboratory data from SDG K0501 were submitted for third-party validation to Level C. Level C validation procedures are specified in Data Validation Procedure for Chemical Analysis (BHI 2000a) and Data Validation Procedure for Radiochemical Analysis (BHI 2000b).

Level $\mathrm{C}$ validation procedures were used to review and qualify the data for the following parameters:

- Sample holding times

- Method blanks 
- MS/MSD recovery

- Surrogate recovery

- Sample replicates (duplicates)

- Laboratory control sample (LCS) results

- Data package completeness

- Achievement of required detection limits (RDLs) or contract required quantitation limits

Data qualified as rejected (i.e., "R" flagged) indicate that the associated analytical result is tainted by a major deficiency in the quality of the data. Rejected data are unsuitable for decision-making purposes. Data qualified as estimated (i.e., "J" flagged) indicate that the data is estimated but may be used for decision-making purposes. Data qualified as undetected (i.e., "U" flagged) indicate the analyte was analyzed for, but it was not detected. For nonradionuclides, nondetected data are reported at the practical quantitation limit (PQL). For radionuclides, nondetected data are reported at the actual value obtained from analysis (positive or negative - but less than the MDA), except for limited analyses where no value can be calculated and the analytes are reported nondetected at the MDA. All other validated results are considered accurate within the standard errors associated with the methods.

The adequacy of laboratory QA/QC was evaluated for precision, accuracy, completeness, and RDLs pursuant to the SAP (DOE-RL 2001). The organization performing the data validation reported that, of the data given formal validation, the laboratory met the standards for performance for precision $( \pm 30 \%)$, accuracy $( \pm 30 \%)$, and completeness $(>90 \%)$.

\section{SDG K0501}

This data package contains two samples (J134T9, J134V0). Sample J134T9 is a shallow zone sample (A2 main), and sample J134V0 is the corresponding field duplicate. No equipment blank was collected for this site. SDG K0501 was evaluated through a formal third-party validation process.

- Radionuclides. No major or minor deficiencies were found in the SDG K0501 radiological data.

- Nonradionuclides. No major deficiencies were found in the SDG K0501 nonradiological data. Minor deficiencies are as follows:

- The inductively coupled plasma (ICP) metals analysis laboratory control sample and matrix spike (MS) recoveries for silicon are below the acceptance criteria at $32.6 \%$ and $33.0 \%$, respectively. The relative percent difference (RPD) calculated for silicon in the laboratory duplicate is above the acceptance criteria at $49 \%$. Third-party validation qualified all of the silicon data in SDG K0501 as estimated with "J" flags for the MS and RPD results. Estimated data are useable for decision-making purposes.

- The ICP metals analysis MS recovery for antimony is below the acceptance criteria at $58.0 \%$. Third-party validation qualified all of the antimony data in SDG K0501 as estimated with "J" flags. Estimated data are useable for decision-making purposes.

- The ICP metals analysis MS recoveries for aluminum, iron, and manganese were outside of the acceptance criteria range. Because MSs are prepared using sample matrix, and the composition of the sample matrix is not known ahead of time, it is common for the spike 
concentration(s) to be insignificant for some analytes compared to the sample matrix concentrations. To confirm quantitation of these analytes, post-digestion spikes (PDSs) are prepared and serial dilutions performed. The PDS recoveries for aluminum, iron, manganese, antimony and silicon were all acceptable, in the range of $94.6 \%$ to $102.2 \%$. No qualifiers were added to the aluminum, iron, or manganese data. The data are useable for decision-making purposes.

- Limited, random, or sample matrix-specific influenced batch quality control (QC) issues such as these are a potential problem for any analysis. The number and types seen in this data set are within expectations for the matrix types and analyses performed. All of the data in SDG K0501 are useable for decision-making purposes.

\section{B1.4.0 LABORATORY DATA EVALUATION}

The following paragraphs include a data evaluation of the remaining verification sample SDGs (J00089, J00090, K0502, K0507, K0508, and K0517) for the 118-F-3 waste site. Comments on the comparability of the samples, project splits, and EPA splits are presented in section B1.5.

\section{SDG J00089}

This data set comprises one field sample (J134V1). Sample J134V1 is the project split of the shallow zone A2 sample (J134T9).

Radionuclides. No major or minor deficiencies were found in the SDG J00089 radiological data.

Nonradionuclides. No major deficiencies were found in the SDG J00089 nonradiological data. Minor deficiencies are as follows:

In the ICP metals analysis, the analytes boron, calcium, potassium, sodium, and zinc were all found in the method blank (MB). For each analyte, this method blank contamination is insignificant compared to the sample J134V1 concentration. There is no impact on the field sample data; the data are useable for decision-making purposes.

\section{SDG J00090}

This data set comprises two field samples (J134Y6, J13543). Sample J134Y6 is the project split of the overburden A2 sample (J134Y2). Sample J13543 is the project split of the suspected above contaminant level (ACL) A3 sample (J13541).

Radionuclides. No major or minor deficiencies were found in the SDG J00090 radiological data.

Nonradionuclides. One major deficiency was found in the SDG J00090 nonradiological data. Major and minor deficiencies are as follows:

In the ICP metals analysis, the MS recovery for silicon was below the acceptance criteria at $8.5 \%$. MS recoveries below the acceptance criteria generally result in associated data that are considered estimated. However, when the MS recovery drops below $10 \%$ the data is, with few exceptions, rejected. The project has qualified the silicon data in SDG J00090 as rejected with 
"R" flags assigned to the data. The silicon data in SDG J00090 are not acceptable for decisionmaking purposes.

In the ICP metals analysis, the MS recoveries for the analytes aluminum, iron, and manganese are outside the established QC limits. The MSs were prepared with added spike concentrations for these analytes that are well below the sample matrix concentrations. The MS recoveries have been overshadowed by the analytical variability and natural heterogeneities in the sample matrix. Method performance is demonstrated by acceptable LCS recoveries. The data are useable for decision-making purposes.

In the ICP metals analysis, the MS recoveries for the analytes antimony, zinc, silver, cadmium, chromium, and magnesium are outside the established QC limits. The RPDs and LCS recoveries are within the acceptable ranges for these analytes. Method performance is demonstrated by the acceptable LCS recoveries. The data are useable for decision-making purposes.

In the ICP metals analysis, the MS recovery for mercury is above the established QC limits. The RPDs and LCS recoveries are within the acceptable range for mercury. Method performance is demonstrated by the acceptable LCS recoveries. A possible high bias is suggested in the data. High-biased data are useable for decision making purposes.

In the ICP metals analysis, the analytes - calcium and copper - were found in the MB. For both analytes, the method blank contamination concentration is insignificant compared to the field sample concentrations. There is no impact on the field sample data; the data are useable for decision-making purposes.

\section{SDG K0502}

This data set comprises four field samples (J134T6, J134T7, J134T8, J134Y0). Sample J134T6 is the shallow zone A1 sample. Sample J134T7 is the shallow zone A4 sample. Sample J134T8 is the shallow zone A3 sample. Sample J134Y0 is a sample of a black ash/soil found near the site excavation.

Radionuclides. No major deficiencies were found in the SDG K0502 radiological data. Minor deficiencies are as follows:

The RPD calculated for strontium-90 is above the acceptance criteria at $183 \%$. Elevated RPDs are attributed to natural heterogeneities in the sample matrix. The strontium-90 data in SDG K0502 are considered estimated but useable for decision-making purposes.

Nonradionuclides. No major deficiencies were found in the SDG K0502 nonradiological data. Minor deficiencies are as follows:

In the ICP metals analysis, the LCS recovery for silicon is below the acceptance criteria at $59.3 \%$. The silicon data in SDG K0502 are considered estimated but useable for decisionmaking purposes.

In the ICP metals analysis, the MS recoveries for the analytes aluminum, iron, manganese, and silicon are outside the established QC limits. The spike concentrations added for these analytes is well below the sample matrix concentrations from which the MSs were prepared. Method performance is demonstrated by preparation and analysis of PDSs and by serial dilutions. The 
PDS recoveries are within the acceptance range at $94.5 \%$ to $101.4 \%$. The data are useable for decision-making purposes.

In the ICP metals analysis, the MS recovery for antimony is outside the established QC limits. The spike concentration added for antimony is much greater than was found in the sample matrix. In this case, the MS recovery is subject to analytical variability and probable matrix interference. The antimony data in SDG K0502 are considered estimated but useable for decision-making purposes.

In the ICP metals analysis, the RPD calculated for boron was above the acceptance criteria at $34.1 \%$. Elevated RPDs are attributed to natural heterogeneities in the sample matrix. The boron data in SDG K0502 are considered estimated but useable for decision-making purposes.

\section{SDG K0507}

This data set comprises three field samples (J134Y1, J134Y4, J134Y5). Sample J134Y1 is the overburden A1 sample. Sample J134Y4 is the overburden A3 sample. Sample J134Y5 is the overburden A4 sample.

Radionuclides. No major or minor deficiencies were found in the SDG K0507 radiological data.

Nonradionuclides. No major or minor deficiencies were found in the SDG K0507 nonradiological data.

\section{SDG K0508}

This data set comprises four field samples (J134Y2, J134Y3, J13541, J13542). Sample J134Y2 is the overburden A2 sample. Sample J134Y3 is the field duplicate of sample J134Y2. Sample J13541 is the ACL staging pile footprint A3 sample. Sample J13542 is the field duplicate of sample J13541.

Radionuclides. No major or minor deficiencies were found in the SDG K0508 radiological data.

Nonradionuclides. No major deficiencies were found in the SDG K0508 nonradiological data.

In the ICP metals analysis, the LCS recovery for silicon was below the acceptance criteria at $16.2 \%$. The silicon data in SDG K0508 are considered estimated but useable for decisionmaking purposes.

In the ICP metals analysis, the MS recoveries for the analytes aluminum, iron, and silicon are outside the established QC limits. The spike concentrations added for these analytes are well below the sample matrix concentrations from which the MSs were prepared. Method performance is demonstrated by the preparation and analysis of PDSs and by serial dilutions. The PDS recoveries are within the acceptance range at $97.5 \%$ to $102.5 \%$ for all four analytes. The data are useable for decision-making purposes.

In the ICP metals analysis, the MS recovery for antimony is outside the established QC limits. The spike concentration added for antimony is much greater than was found in the sample matrix. In this case, the MS recovery is subject to analytical variability and probable matrix interference. The antimony data in SDG K0508 are considered estimated but useable for decision-making purposes. 
In the ICP metals analysis, the RPDs calculated for arsenic, chromium (total), and nickel are above the acceptance criteria at $32.6 \%, 74.2 \%$, and $56.8 \%$, respectively. Elevated RPDs are attributed to natural heterogeneities in the sample matrix. The arsenic, chromium (total), and nickel data in SDG K0508 are considered estimated but useable for decision-making purposes.

\section{SDG K0517}

This data set comprises three field samples (J13538, J13539, J13540). Sample J13538 is the above cleanup level (ACL) staging pile footprint A1 sample. Sample J13539 is the ACL staging pile footprint A2 sample. Sample $\mathrm{J} 13540$ is the $A C L$ staging pile footprint A4 sample.

Radionuclides. No major or minor deficiencies were found in the SDG K0517 radiological data.

Nonradionuclides. No major or minor deficiencies were found in the SDG K0517 nonradiological data.

\section{SDG 0600051}

This data set comprises five EPA-split field samples (EPA-J134T8, EPA-J134T9, EPA-J134Y0, EPA-J134Y2, EPA-J13541). Sample EPA-J134T8 is the EPA split of the shallow zone A3 sample, J134T8. Sample EPA-J134T9 is the EPA split of the shallow zone A2 sample, J134T9. Sample EPA-J134Y0 is the EPA split of the shallow zone black ash/soil sample, J134Y0. Sample EPA-J134Y2 is the EPA split of the BCL overburden A2 sample, J134Y2. Sample EPAJ13541 is the EPA split of the ACL staging pile footprint A3 sample, J13541.

Radionuclides. No major deficiencies were found in the SDG 0600051 radiological data.

Due to technical reasons involving decay rates, overlapping spectral lines, indirect calculation, and holding times, the EPA split sample laboratory (U.S. Environmental Protection Agency National Air and Radiation Environmental Laboratory) has placed an asterisk on all of the data for two of the analytes (radium-226, uranium-235) that appear on both the main and split sample analyte lists. The laboratory's intent is to indicate that the data are estimated. For the purposes of this DQA and the calculations that appear in Appendix $\mathrm{C}$, the asterisks have been replaced with "J" flags to indicate that the data are qualified as estimated. Estimated data are useable for the intended data comparison.

Nonradionuclides. No major or minor deficiencies were found in the SDG 0600051 nonradiological data.

The context for assessing the data includes evaluating the sample data using the statistical methodology and parameters specified in the SAP. This section summarizes the results of the comparison and presents an evaluation of the data.

\section{B1.4.1 MAJOR DEFICIENCIES}

Any data anomaly that causes final data to be qualified as rejected ("R" flagged) is considered a major deficiency. One major deficiency (MS recovery) is identified in the 118-F-3 data set, see discussion under SDG J00090. 


\section{B1.4.2 MINOR DEFICIENCIES}

Sample Holding Times. All of the method-specific holding times were met for all samples in the $118-\mathrm{F}-3$ verification data set.

Method Blanks. The method blank is used to evaluate false-positive results in samples due to contamination during handling at the laboratory.

Radionuclides. All of the radionuclide method blank results were within the acceptance criteria.

Nonradionuclides. Minor method blank deficiencies are identified in two SDGs (See SDGs J00089 and J00090) in the 118-F-3 verification data set.

MS/MSDs Recoveries. Recovery of spiked analytes in the MS/MSD pair is used to evaluate method efficiency and the effect of the sample matrix on the environmental sample results.

Radionuclides. All MS/MSD recoveries for radionuclide COCs were within acceptance criteria.

Nonradionuclides. Minor deficiencies in the MS/MSD recoveries are identified in SDGs K0501, K0502, K0508 and J00090. The data are within project specified criteria and are useable for decision-making purposes.

RDL Comparison. Reported analytical detection levels for nondetected analytes were compared to the RDLs specified in the SAP (DOE-RL 2001). When detected results were obtained, evaluation of detection limits was not performed.

Radionuclides. All of the reported COC MDAs are sufficiently low for decision-making purposes. All values meet the site cleanup criteria as demonstrated in the calculation briefs (Appendix $\mathrm{C}$ ) and discussed in this cleanup verification package.

Nonradionuclides. All of the reported MDLs are sufficiently low for decision-making purposes. All values meet the site cleanup criteria as discussed in this cleanup verification package.

Precision and Accuracy Evaluation. RPD evaluation of the main sample versus the laboratory duplicate are routinely performed by laboratory, and any deficiencies in those calculations are reported by SDG in section B1.4.0.

\section{B1.5 FIELD QUALITY ASSURANCE/QUALITY CONTROL}

Field QA/QC measures were used to assess potential sources of error and cross contamination of soil samples that could bias results. Field QA/QC samples listed in the field logbook (WCH 2006a) are summarized in Table B-1. The main and QA/QC sample results are presented in Appendix A. 
Table B-1. Summary of Field Quality Control Samples.

\begin{tabular}{|c|c|c|c|c|}
\hline Sample & Main & Duplicate & Project-split & EPA-split \\
\hline Shallow zone A3 & J134T8 & N/A & N/A & EPA-J134T8 \\
\hline Shallow zone A2 & J134T9 & J134V0 & J134V1 & EPA-J134T9 \\
\hline Shallow zone black ash & J134Y0 & N/A & N/A & EPA-J134Y0 \\
\hline Overburden A2 & J134Y2 & J134Y3 & J134Y6 & EPA-J134Y2 \\
\hline $\begin{array}{c}\text { Staging Pile Footprint } \\
\text { (ACL) A3 }\end{array}$ & $\mathrm{J} 13541$ & $\mathrm{~J} 13542$ & $\mathrm{~J} 13543$ & EPA-J13541 \\
\hline
\end{tabular}

Field duplicate samples are collected in order to measure the degree of local heterogeneity in the sampling medium, unlike laboratory duplicates that are used to evaluate precision in the analytical process. The field duplicates are evaluated by computing the RPD of the duplicate samples for each COC. Only analytes with values above five times the detection limits for both the main and duplicate samples are compared. The 95\% upper confidence limit (UCL) calculation brief in Appendix C provides details on duplicate pair evaluation and RPD calculation. The data are suitable for the intended purpose of cleanup verification.

Split samples (both project- and EPA-split) are collected in order to measure the degree of variability in the sampling, sample handling, and analytical techniques used by commercial laboratories. The field main and split samples are evaluated by computing the RPD of the split samples for each COC to determine the usability of the verification data. The U.S.

Environmental Protection Agency Contract Laboratory Program duplicate sample comparison methodology, USEPA Contract Laboratory Program National Functional Guidelines for Inorganic Data Review (EPA 1994), is used as an initial test of the data from the splits. Only analytes that had values above five times the contractual RDL for both the main and split sample were compared. The 95\% UCL calculation brief in Appendix C provides details on the split-pair RPD calculation. The acceptance criteria for RPDs is $\leq 30 \%$ for all but the EPA-split samples where the acceptance criteria is $\leq 35 \%$.

Radionuclides. The RPDs calculated for potassium- 40 in the overburden and the waste staging area duplicates were above the acceptance criteria (30\%) at $45 \%$ and $54 \%$, respectively. The EPA-split sample potassium-40 RPDs, for the shallow zone A2 sample and the black ash sample, were above the acceptance criteria (35\%) at $41 \%$ and $47 \%$, respectively. Elevated RPDs, such as these, in the analysis of environmental soil samples, are in a large part attributed to heterogeneities in the soil matrix, and only in a small part attributed to precision and accuracy issues at the laboratory.

A secondary check of the data variability is used to check the data when one or both of the samples being evaluated (main and duplicate or main and split) is less than 5 times the target detection limit (TDL), including undetected analytes. In these cases, a control limit of \pm 2 times the TDL is used (Appendix C) to indicate that a visual check of the data is required by the reviewer. A visual inspection of the data revealed that the variability indicated by this secondary check can be explained by differences in MDAs between the laboratories and/or low level detections of the analytes in one or the other of the samples. No major deficiencies were noted. The data are useable for decision-making purposes. 
Nonradionuclides. The RPDs calculated for aluminum in the EPA-splits of the shallow zone $\mathrm{A} 2, \mathrm{~A} 3$, and black ash samples are $61.0 \%, 73.0 \%$, and $118 \%$, respectively. The RPDs calculated for aluminum in the EPA-splits of the overburden and waste staging area are $51.0 \%$ and $71.0 \%$, respectively.

The RPD calculated for barium in the EPA-split sample of the shallow zone A2 sample is $79.0 \%$.

The RPDs calculated for calcium in the EPA-split samples of the overburden and waste staging samples are $200 \%$ and $43.0 \%$, respectively.

The RPDs calculated for total-chromium in the EPA-splits of the shallow zone A2, A3, and black ash samples are $36.0 \%, 54.0 \%$, and $73.0 \%$, respectively.

The RPDs calculated for copper in the EPA-splits of the shallow zone A3, and black ash samples are $35.0 \%$ and $45.0 \%$, respectively.

The RPDs calculated for iron in the EPA-splits of the shallow zone A3, and black ash, samples are $55.0 \%$ and $59.0 \%$, respectively. The RPDs calculated for iron in the EPA-splits of the overburden and waste staging area samples are $35.0 \%$ and $50.0 \%$, respectively. The RPD calculated for iron in the project-split of the waste staging area sample is $39.8 \%$.

The RPDs calculated for magnesium in the EPA-splits of the shallow zone A3 sample and waste staging area samples are $47.0 \%$ and $38.0 \%$, respectively.

The RPDs calculated for silicon in the duplicate and split analysis of the shallow zone A2 sample are $42.2 \%$ and $73.6 \%$, respectively.

The RPD calculated for sodium in the EPA-split analysis of the black ash sample is $62.0 \%$.

The RPDs calculated for vanadium, in the EPA-splits of the shallow zone A3, and black ash samples are $51.0 \%$ and $60.0 \%$, respectively. The RPD calculated for vanadium in the EPA-split of the waste staging area sample is $40.0 \%$. The RPD calculated for vanadium in the projectsplit of the waste staging area sample is $42.4 \%$.

All of these results are, to a large extent, attributed to heterogeneities in the soil matrix, and only in a small part attributed to precision and accuracy issues at the laboratory. The data are useable for decision-making purposes.

RPDs for the remaining nonradionuclide analytes were either within the acceptance criteria or were not calculated because an evaluation of the data shows the analytes were not detected in both the main and duplicate (or main and split) sample at more than 5 times the TDL. RPDs of analytes detected at low concentrations (less than five times the TDL) are not considered indicative of the analytical system performance.

A secondary check of the data variability is also used to check the data when one or both of the samples being evaluated (main and duplicate or main and split) is less than 5 times the TDL, including undetected analytes. In these cases, a control limit of \pm 2 times the TDL is used (Appendix $\mathrm{C}$ ) to indicate that a visual check of the data is required by the reviewer. A visual inspection of the data revealed that the variability indicated by this secondary check can be explained by differences in PQLs between the laboratories and/or low level detections of the 
analytes in one or the other of the samples. No major deficiencies were noted. The data are useable for decision-making purposes.

\section{B1.6 SUITABILITY OF DATA}

The DQA for the 118-F-3 waste site determined that the data are of the right type, quality, and quantity to support site cleanup verification decisions within specified error tolerances. The DQA verified that the sample design was sufficient for the purpose of clean site verification. With the exception of the silicon data in SDG J00090, all analytical data were found to be acceptable for decision-making purposes.

\section{B2.0 REFERENCES}

BHI, 2000a, Data Validation Procedure for Chemical Analysis, BHI-01435, Rev. 0, Bechtel Hanford, Inc., Richland, Washington.

BHI, 2000b, Data Validation Procedure for Radiochemical Analysis, BHI-01433, Rev. 0, Bechtel Hanford, Inc., Richland, Washington.

DOE-RL, 2001, 100 Area Burial Grounds Remedial Action Sampling and Analysis Plan, DOE/RL-2001-35, Rev. 0, U.S. Department of Energy, Richland Operations Office, Richland, Washington.

DOE-RL, 2005, Remedial Design Report/Remedial Action Work Plan for the 100 Area, DOE/RL-96-17, Rev. 5, U.S. Department of Energy, Richland Operations Office, Richland, Washington.

EPA, 1994, USEPA Contract Laboratory Program National Functional Guidelines for Inorganic Data Review, EPA 540/R-94/013, U.S. Environmental Protection Agency, Washington, D.C.

EPA, 2000, Guidance for Data Quality Assessment, EPA QA/G-9, QA00 Update, EPA/600/R-96/084, U.S. Environmental Protection Agency, Office of Environmental Information, Washington, D.C.

WCH, 2006, Remedial Sampling, Logbook EFL-1174-1, Washington Closure Hanford, Richland, Washington. 
Rev. 0

B-12 
Rev. 0

\section{APPENDIX C}

\section{CALCULATION BRIEF EXCERPTS}


CVP-2006-00008

Rev. 0

C-ii 


\section{DISCLAIMER FOR CALCULATIONS}

The calculations that are provided in the following appendix have been generated to document compliance with established cleanup levels. These calculations should be used in conjunction with other relevant documents in the administrative record. 


\section{CALCULATION BRIEFS}

The following calculation briefs have been prepared in accordance ENG-1, Engineering Services, Eng-1-4.5, "Project Calculations", Washington Closure Hanford, Richland, Washington.

118-F-3 Shallow Zone, ACL, and BCL Overburden Sampling Plan, Calculation Number 0100FCA-V0268, Rev. 0, Washington Closure Hanford, Richland, Washington.

118-F-3 Waste Site Cleanup Verification 95\% UCL Calculations, Calculation Number 0100FCA-V0273, Rev. 0, Washington Closure Hanford, Richland, Washington.

NOTE: The calculation briefs referenced in this appendix are kept in the active Washington Closure Hanford project files and are available upon request. When the project is completed, the files will be stored in a U.S. Department of Energy, Richland Operations Office repository. Only excerpts of the calculation briefs are included in this appendix. 


\section{CALCULATION COVER SHEET}

Project Title:

\section{Area}

Discipline

Subject

Computer Program
118-F-3 Burial Ground Sample Design $100-\mathrm{F}$

Environmental Engineering $\quad{ }^{*}$ Calc. No. $0100 \mathrm{~F}-\mathrm{CA}-\mathrm{V} 0268$

118-F-3 Shallow Zone, ACL, and BCL Overburden Sampling Plan

Excel Program No. Excel 2003

The attached calculations have been generated to document compliance with established cleanup levels. These calculations should be used in conjuction with other relevent documents in the administrative record.

\section{Committed Calculation $\square \quad$ Preliminary $\square \quad$ Superseded $\square \quad$ Voided $\square$}

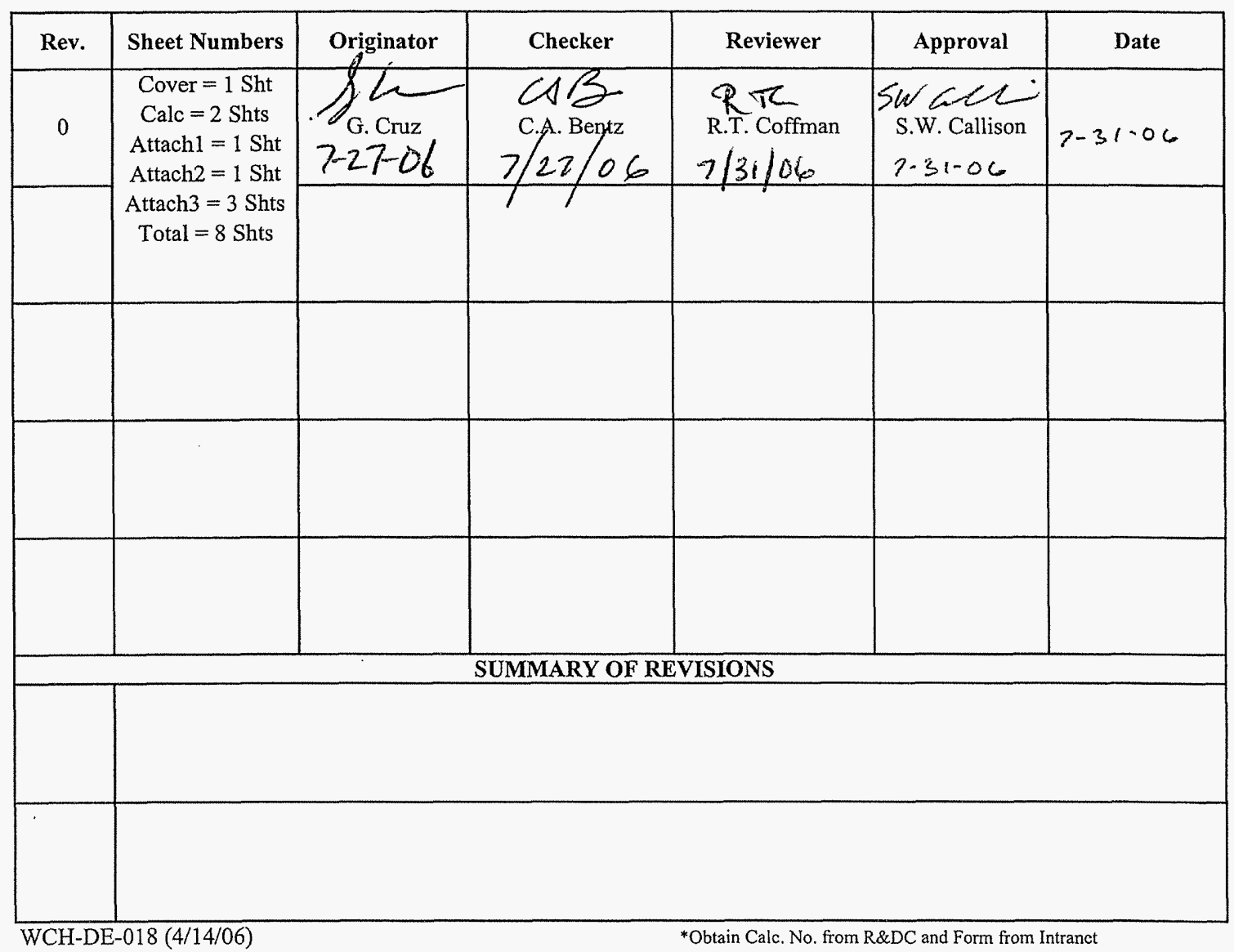




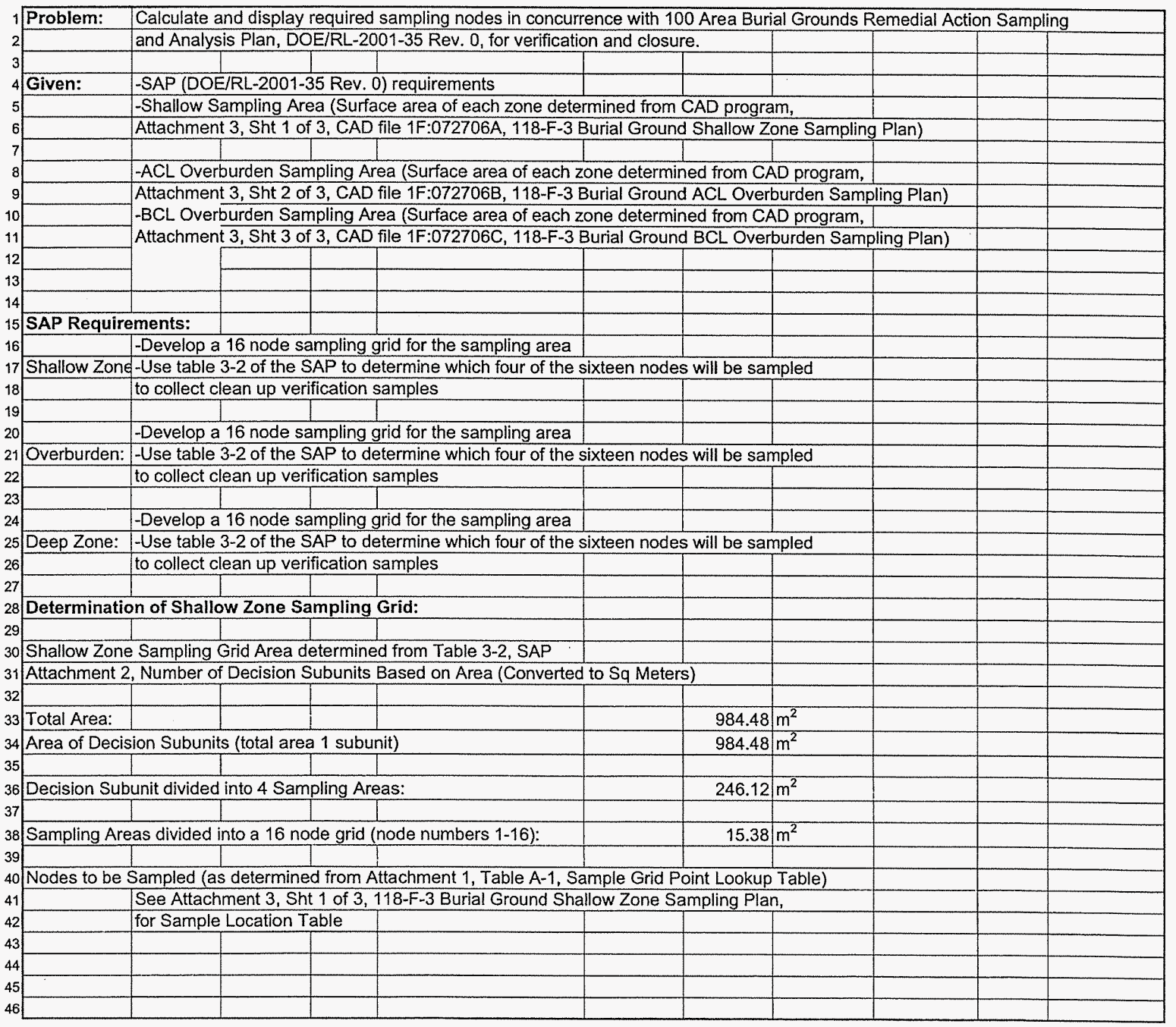




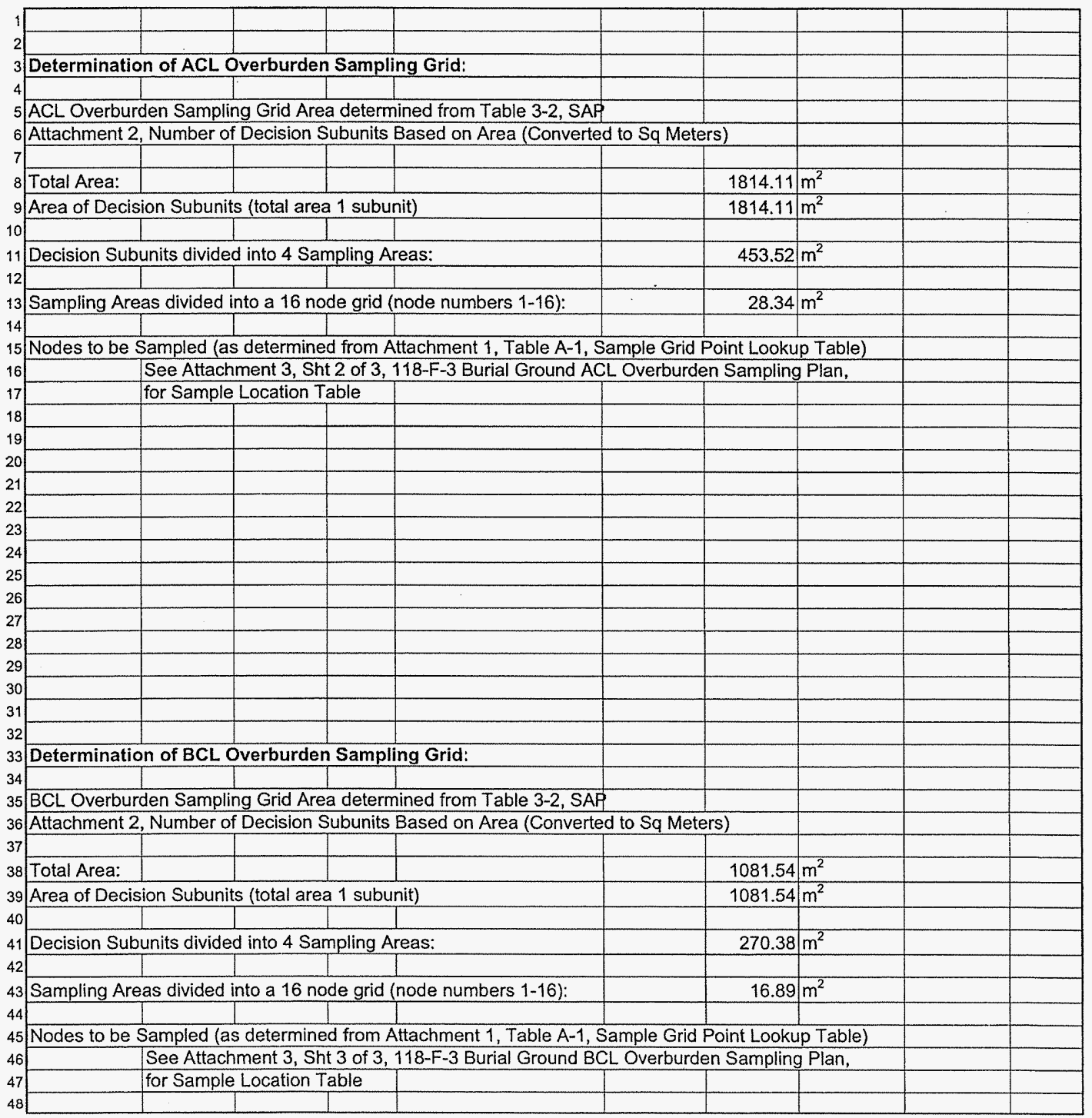


CVP-2006-00008

Rev. 0

Washington Closure Hanford

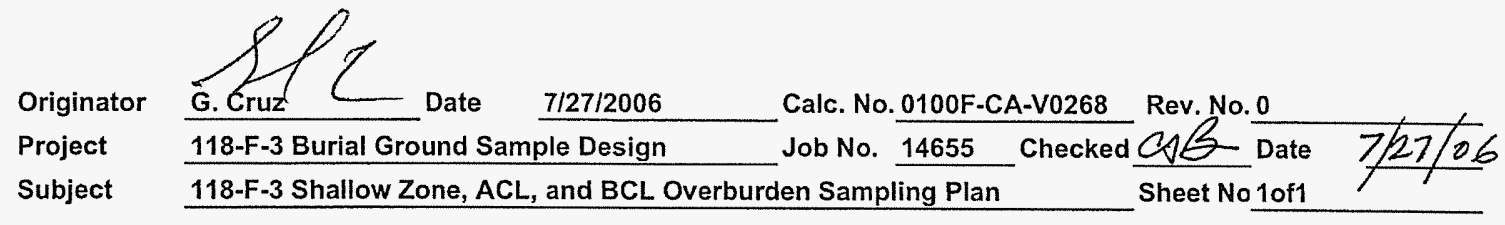

\begin{tabular}{|c|c|c|c|c|c|c|c|c|c|c|c|}
\hline \multicolumn{12}{|c|}{$\begin{array}{l}1 \text { ATTACHMENT } 1 \\
{ }_{3} \text { Sample Grid Point Lookup Table. }\end{array}$} \\
\hline 6 & Default Plan, & $\begin{array}{c}\text { Sampling } \\
\text { Area 1 }\end{array}$ & $\begin{array}{c}\text { Sampling } \\
\text { Area } 2 \\
\end{array}$ & $\begin{array}{c}\text { Sampling } \\
\text { Area } 3\end{array}$ & $\begin{array}{c}\text { Sampling } \\
\text { Area } 4\end{array}$ & $\begin{array}{c}\text { Sampling } \\
\text { Area } 5\end{array}$ & $\begin{array}{c}\text { Sampling } \\
\text { Area } 6\end{array}$ & $\begin{array}{l}\text { Sampling } \\
\text { Area } 7\end{array}$ & $\begin{array}{c}\text { Sampling } \\
\text { Area } 8\end{array}$ & $\begin{array}{c}\text { Sampling } \\
\text { Area } 9\end{array}$ & $\begin{array}{c}\text { Sampling } \\
\text { Area } 10\end{array}$ \\
\hline 7 & Closeout & 3 & 6 & 1 & 4 & 5 & 1 & 3 & 3 & 4 & 16 \\
\hline 8 & Closeout & 4 & 7 & 11 & 3 & 15 & 15 & 5 & 13 & 10 & 10 \\
\hline 9 & Closeout & 16 & 3 & 2 & 7 & 7 & 10 & 11 & 4 & 3 & 14 \\
\hline 10 & Closeout & 10 & 15 & 4 & 12 & 1 & 13 & 4 & 8 & 16 & 4 \\
\hline 11 & Not Sampling & 2 & 14 & 5 & 9 & 13 & 12 & 8 & 2 & 14 & 8 \\
\hline 12 & Not Sampling & 13 & 10 & 9 & 13 & 2 & 16 & 1 & 12 & 5 & 3 \\
\hline 13 & Not Sampling & 6 & 1 & 10 & 8 & 14 & 4 & 16 & 5 & 8 & 6 \\
\hline 14 & Not Sampling & 1 & 9 & 13 & 1 & 10 & 5 & 12 & 1 & 1 & 15 \\
\hline 15 & Not Sampling & 9 & 12 & 7 & 5 & 6 & 2 & 6 & 7 & 15 & 9 \\
\hline 16 & Not Sampling & 15 & 16 & 15 & 14 & 16 & 6 & 2 & 15 & 11 & 1 \\
\hline 17 & Not Sampling & 8 & 13 & 8 & 10 & 12 & 11 & 13 & 14 & 2 & 12 \\
\hline 18 & Not Sampling & 5 & 2 & 3 & 11 & 4 & 3 & 9 & 10 & 7 & 11 \\
\hline 19 & Not Sampling & 7 & 11 & 14 & 15 & 11 & 14 & 14 & 6 & 13 & 2 \\
\hline 20 & Not Sampling & 11 & 4 & 6 & 2 & 9 & 7 & 7 & 11 & 9 & 7 \\
\hline 21 & Not Sampling & 12 & 8 & 16 & 16 & 3 & 8 & 15 & 8 & 6 & 13 \\
\hline 22 & Not Sampling & 14 & 5 & 12 & 6 & 8 & 9 & 10 & 16 & 12 & 5 \\
\hline
\end{tabular}

nodes in the northwesternmost node. Then number consecutively left to right. 


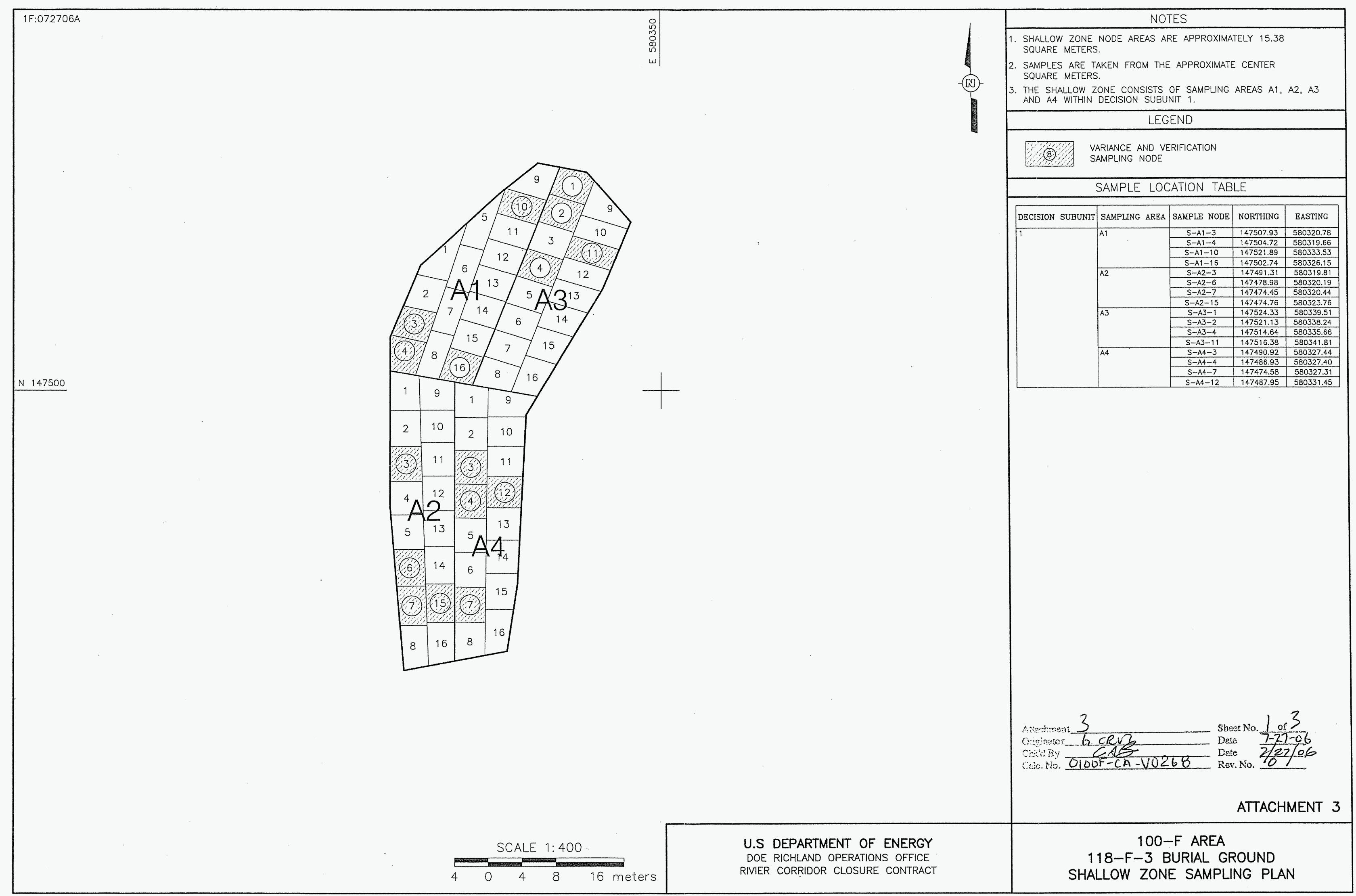




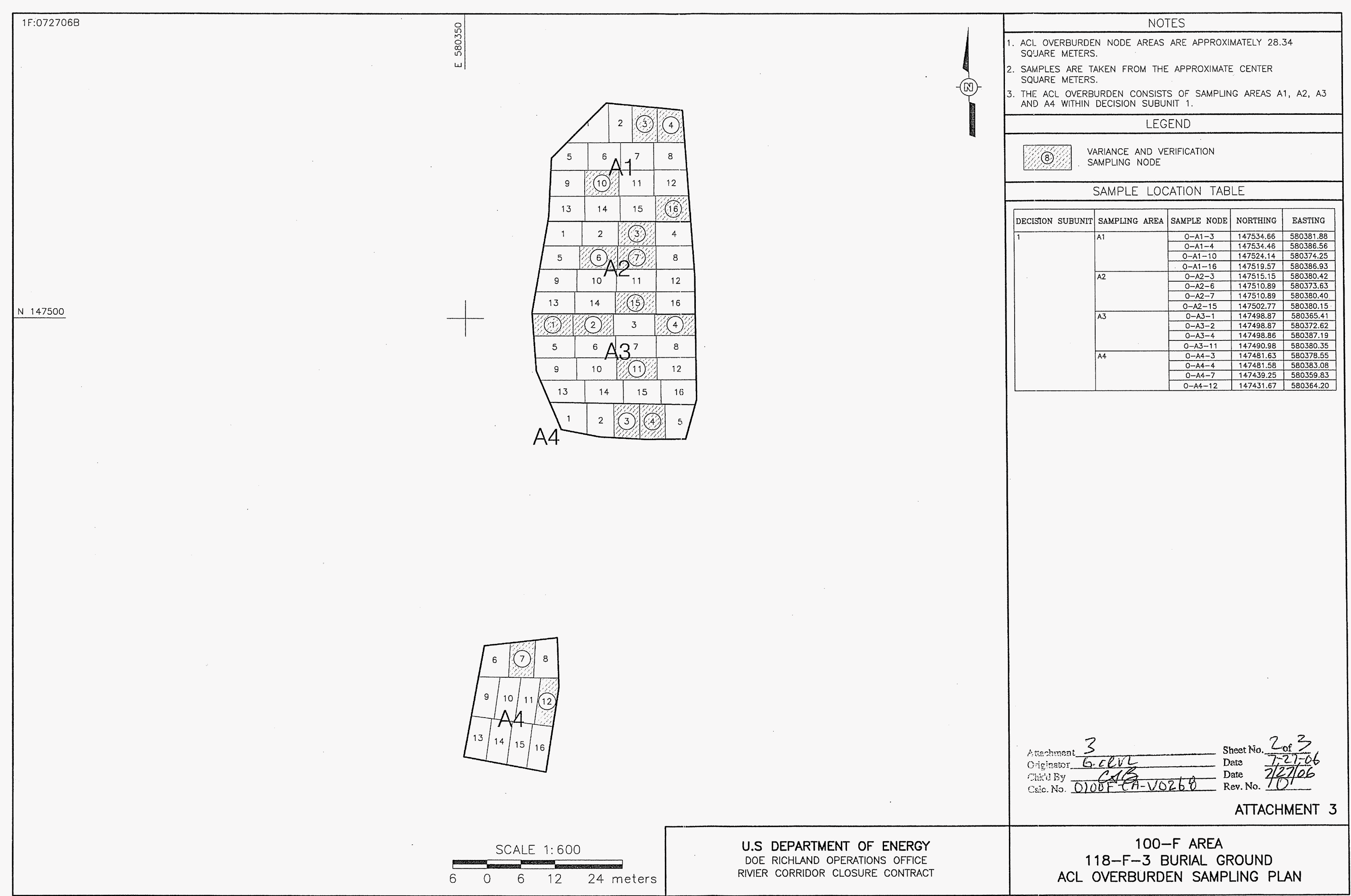




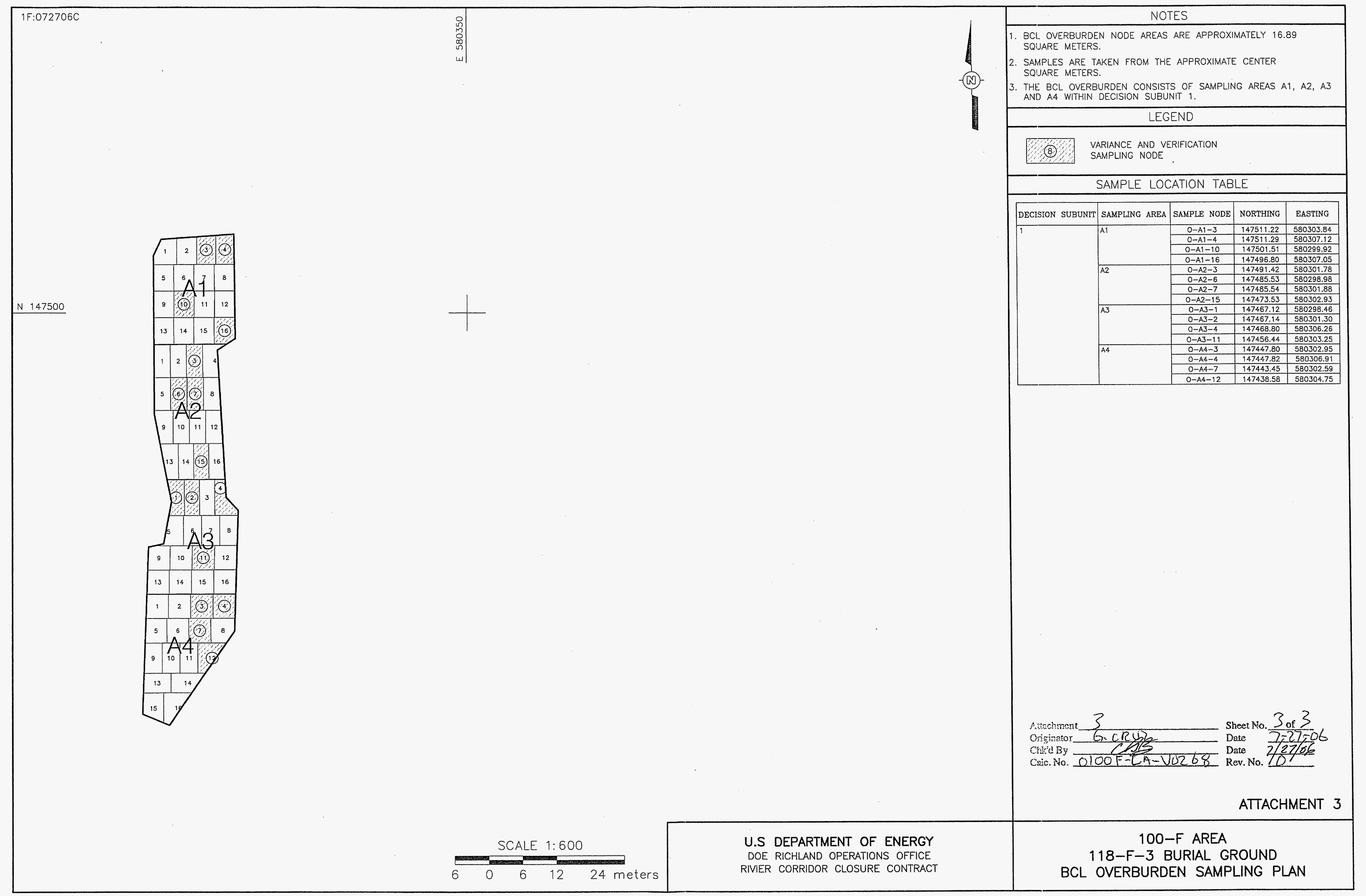




\section{CALCULATION COVER SHEET}

Project Title:

Area

Discipline

Subject

Computer Program
100-F Area Field Remediation

$100-\mathrm{F}$

Environmental

118-F-3 Cleanup

Excel
Job No.

${ }^{*}$ Calc. No. $\quad 0100$ F-CA-V0273

ations

Program No. Excel 2003

The attached calculations have been generated to document compliance with established cleanup levels. These calculations should be used in conjunction with other relevant documents in the administrative record.

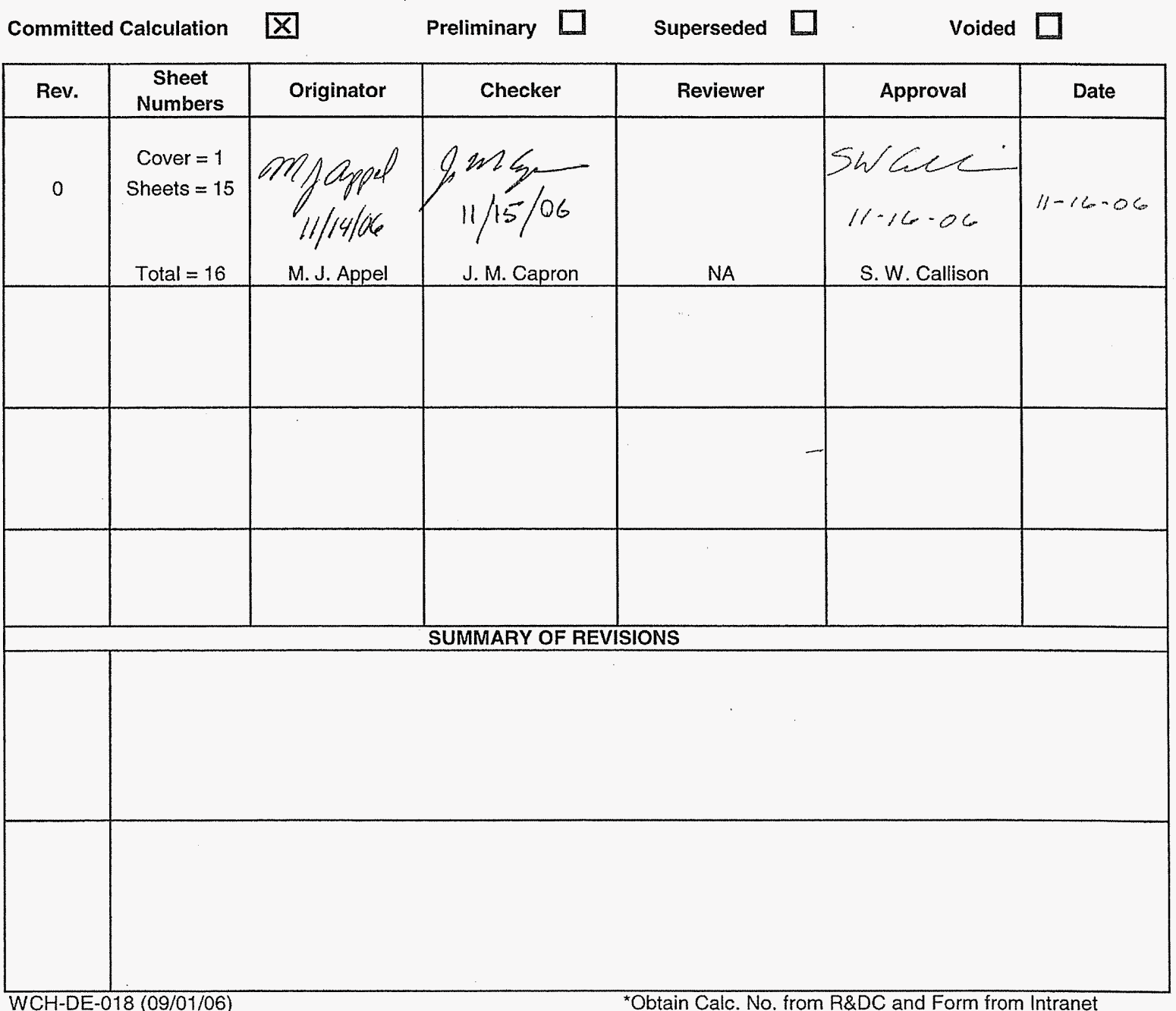


Washington Closure Hanford

Originator M. J. Appel $\mathscr{P} / A$

Project $100-\mathrm{F}$ Area Field Retmediation

Subject $118-\mathrm{F}-3$ Cleanup Verification $95 \%$ UCL Calculations
Date $11 / 14 / 06$ Job No. 14655

\section{CALCULATION SHEET}

Calc. No. 0100F-CA-V0273 Checked J.M. Capron ginc $\begin{array}{rc}\text { Rev. No. } & \frac{0}{11 / 15 / 06} \\ \text { Date } & \frac{1 / 0 \text { f } 15}{\text { Sheet No. }}\end{array}$

Summary

1 Purpose:

2 Calculate the $95 \%$ upper confidence limit (UCL) to evaluate compliance with cleanup standards for the subject site. Also, calculate the carcinogenic risk for applicable nonradionuclide analytes, perform the Washington Administrative Code (WAC) 173-340 (Model Toxics Control Act [MTCA]) 3 part test, if required, and calculate the relative percent difference (RPD) for each contaminant of concern (COC) and contaminant of potential concern (COPC)

Table of Contents:

Sheets 1 to 4 - Calculation Sheet Summary

Sheet 5 - Calculation Sheet Shallow Zone Verification

Sheet 6 - Calculation Sheet Overburden Verification

Sheet 7 - Calculation Sheet Waste Staging Area Verification

Sheets 8 to 15 - Calculation Sheet Split-Duplicate Analysis

4 Given/References:

1) Background values and remedial action goals (RAGs) are taken from DOE-RL (2005), DOE-RL (2001), and Ecology (2005).

2) DOE-RL, 1996, Hanford Site Background: Part 2, Soil Background for Radionuclides, DOE/RL-96-12, Rev. 0, U.S. Department of Energy, Richland Operations Office, Richland, Washington.

3) DOE-RL, 2001, Hanford Site Background: Part 1, Soil Background for Nonradioactive Analytes, DOE/RL-92-24, Rev. 4, U.S. Department of Energy, Richland Operations Office, Richland, Washington.

4) DOE-RL, 2001, 100 Area Burial Grounds Remedial Action Sampling and Analysis Plan, DOE/RL 2001-35, Rev. 0, U.S. Department of Energy, Richland Operations Office, Richland, Washington.

5) DOE-RL, 2005, Remedial Design Report/Remedial Action Work Plan for the 100 Area (RDR/RAWP), DOE/RL-96-17. Rev. 5, U.S. Department of Energy, Richland Operations Office, Richland, Washington.

6) Ecology, 1992, Statistical Guidance for Ecology Site Managers, Publication \#92-54, Washington Department of Ecology, Olympia, Washington.

7) Ecology, 1993, Statistical Guidance for Ecology Site Managers, Supplement S-6, Analyzing Site or Background Data with Below-detection Limit or Below-PQL Values (Censored Data Sets), Publication \#92-54, Washington Department of Ecology, Olympia, Washington.

8) Ecology, 2005, Cleanup Levels and Risk Calculations (CLARC) Database, Washington State Department of Ecology, Olympia, Washington, <https://fortress.wa.gov/ecy/clarc/CLARCHome.aspx>.

9) EPA, 1994, USEPA Contract Laboratory Program National Functional Guidelines for Inorganic Data Review, EPA 540/R-94/013. U.S. Environmental Protection Agency, Washington, D.C.

10) WAC 173-340, 1996, "Model Toxic Control Act - Cleanup." Washington Administrative Code.

Solution:

Calculation methodology is described in Ecology Pub. \#92-54 (Ecology 1992, 1993), below, and in the RDR/RAWP (DOE-RL 2005). Use data from the attached worksheets to calculate the 95\% UCL, hazard quotients, excess carcinogenic risk, perform the WAC 173-340 3-part test for nonradionuclides, and calculate the RPD for each $\mathrm{COC}$ and $\mathrm{COPC}$ in the primary-duplicate and primary-split sample pairs.

Calculation Description:

The subject calculations were performed on data from soil verification samples from the 118-F-3 waste site. The data were entered into an EXCEL 2003 spreadsheet and calculations performed by utilizing the built-in spreadsheet functions and/or creating formulae within the cells. The statistical 44 evaluation of data for use in accordance with the RDR/RAWP (DOE-RL 2005) is documented by this calculation. Split and duplicate RPD results 45 are used in evaluation of data quality and are presented in the cleanup verification package (CVP) for this site, as necessary.

47 Methodology:

48 For nonradioactive analytes with $<50 \%$ of the data below detection limits and all radionuclide analytes, the statistical value calculated to evaluate 49 the effectiveness of cleanup is the $95 \% \mathrm{UCL}$. For nonradioactive analytes with $>50 \%$ of the data below detection limits, the maximum value for the 50 data set is used instead of the $95 \%$ UCL. All nonradionuclide data reported as being below detection limits are set to $1 / 2$ the detection limit value for 51 calculation of the statistics (Ecology 1993). For radionuclide data, calculation of the statistics was done on the reported value. In cases where the 52 laboratory does not report a value below the minimal detectable activity (MDA), half of the MDA is used in the calculation. For the statistical 53 evaluation of primary-duplicate sample pairs, the samples are averaged before being included in the data set, after adjustments for censored data 54 as described above. 
Originator M. J. Appel MOS

Project $100-\mathrm{F}$ Area Field Remediation

Project $\frac{100-F \text { Area Field Remediation }}{118-F-3 \text { Cleanup Verification } 95 \% \text { UCL Calculations }}$
Date $11 / 14 / 06$

Job No. 14655
Calc. No. 0100F-CA-V0273 Checked J. M. Capron gimC
Rev. No.

Date $11 / 15$ Sheet No. $\frac{2 \text { of } 15}{25}$

Summary (continued)

1 Methodology (continued)

2 The COCs for the 118-F-3 Burial Ground are: barium, boron, cobalt-60, cesium-137, nickel-63, and strontium-90. All other sampling results for the non-COC metal analyses (shallow zone, overburden, and the waste staging pile area) were below background and, therefore, not evaluated. All COCs and all detected non-COCs were included in the evaluation of the RPD calculations for data quality assessment purposes.

6 For nonradionuclides, the WAC 173-340 statistical guidance suggests that a test for distributional form be performed on the data and the $95 \%$ UCL. calculated on the appropriate distribution using Ecology software. For nonradionuclide small data sets $(n<10)$ and all radionuclide data 8 sets, the calculations are performed assuming nonparametric distribution, so no test for distribution is performed. For nonradionuclide data sets 9 of ten or greater, distributional testing is done using Ecology's MTCAStat software (Ecology 1993). Background values are subtracted for 10 applicable radionuclides only. Comparison against background levels for nonradionuclides is included within the CVP.

12 The hazard quotient (for shallow zone nonradionuclide COCs) is determined by dividing the statistical value (derived in this calculation) by the 13 WAC 173-340 non-carcinogenic cleanup limit. The excess nonradionuclide carcinogenic risk is determined by dividing the statistical value by 14 the WAC $173-340$ carcinogenic cleanup limit and then multiplying by $10^{-6}$ : 15

16 The WAC 173-340 3-part test is performed for nonradionuclide analytes only and determines if:

17 1) the $95 \%$ UCL value exceeds the most stringent cleanup limit for each non-radionuclide COC

18 2) greater than $10 \%$ of the raw data exceed the most stringent cleanup limit for each non-radionuclide COC

19 3) the maximum value of the raw data set exceeds two times the most stringent cleanup limit for each non-radionuclide COC.

21 The RPD values are evaluated for analytes detected in a primary-duplicate or primary-split sample pair for the purposes of data quality 22 assessment within the CVP. The RPD is calculated when both the primary value and either the duplicate or split values are above detection 23 limits and are greater than 5 times the target detection limit (TDL). The TDL is a laboratory detection limit pre-determined for each analytical 24 method, listed in Table II-1 of the SAP (DOE-RL 2001). The RPD calculations use the following formula: RPD $=[|M-S| /((M+S) / 2)]^{*} 100$

For quality assurance/quality control (QA/QC) split and duplicate RPD calculations, a value less than $+1-30 \%$ indicates the data compare 29 favorably. For regulatory splits, a threshold of $35 \%$ is used (EPA 1994). If the RPD is greater than $30 \%$ (or $35 \%$ for regulatory split data), further

A regulator-split comparison was required for the 118-F-3 waste site and as such and additional parameter was evaluated. A control limit of $+1-$ 34 times the TDL shall be used if either the main or regulator split value is less than 5 times the TDL and above detection. In the case where only 35 one result is greater than 5 times the TDL and the other is below, the $+1-2$ times the TDL criteria applies. Therefore, the following calculation is 36 performed as part of the evaluation for these two cases involving regulator split data: difference $=$ main - split. If the difference is greater than $+/-$ 2 times the TDL, then further investigation regarding the usability of the data is performed and presented in the applicable CVP data quality 38 assessment section.

40 A regulator-split comparison was not performed for the polychlorinated biphenyls (PCBs) because all PCB values were reported below the 41 detection limits in both the main samples and the regulatory split samples. For the metals and radionuclide data, a regulator split comparison 42 was performed for all analyses that were present in both the main samples and the regulatory split samples. Additional disucssion of these 
Originator M. J. Appel 201 A Project 100 -F Area Field Rémediation Subject $118-\mathrm{F}-3$ Cleanup Verification $95 \%$ UCL Calculatio
Date $11 / 14 / 06$ Job No. 14655 lations
Calc. No. 0100F-CA-V0273 Checked J.M. Capron $12 m$
Rev. No. Date $\frac{0}{11 / 15 / 06}$

Summary (continued)

1 Results:

2 The results presented in the summary tables that follow are for use in the 118-F-3 CVP.

3

\begin{tabular}{|l|c|c|c|c|c|c|c|}
\hline \multirow{2}{*}{ Analyte } & \multicolumn{2}{|c|}{ Shallow Zone } & \multicolumn{2}{|c|}{ Overburden } & Waste Staging Area & \multirow{2}{*}{ Units } \\
\cline { 2 - 7 } & Result & Qualifier & Result & Qualifier & Result & Qualifier & \\
\hline Barium & 104 & & 70.6 & & 99.7 & & $\mathrm{mg} / \mathrm{kg}$ \\
\hline Boron & 10.4 & & 2.4 & & 5.4 & & $\mathrm{mg} / \mathrm{kg}$ \\
\hline Cobalt-60 & 0.378 & & 0.142 & $U$ & 0.299 & & $\mathrm{pCi} / \mathrm{g}$ \\
\hline Cesium-137 & 0.144 & & $0(<\mathrm{BG})$ & $U$ & 0.170 & & $\mathrm{pCi} / \mathrm{g}$ \\
\hline Nickel-63 & 16.5 & & 0.801 & $U$ & 13.4 & & $\mathrm{pCi} / \mathrm{g}$ \\
\hline Strontium-90 & 0.235 & & $0(<\mathrm{BG})$ & $\mathrm{U}$ & 0.045 & $\mathrm{U}$ & $\mathrm{pCi} / \mathrm{g}$ \\
\hline
\end{tabular}

Strontium-90

$3 \mathrm{U}=$ undetected

15 WAC 173-340 Evaluation (Shallow Zone)

16

17 3-Part Test

$1895 \%$ UCL > Cleanup Limit?

$19>10 \%$ above Cleanup Limit?

20 Any sample $>2 x$ Cleanup Limit?

22 Risk Estimate:

23 Nonrad noncarcinogenic index sum:

Nonrad carcinogenic risk:

3-Part Test:

Test:

$95 \%$ UCL > Cleanup Limit?

$>10 \%$ above Cleanup Limit?

NO

NO

Any sample $>2 \times$ Cleanup Limit?

NO

Risk Estimate:

Nonrad noncarcinogenic index sum: $\quad 1.5 \mathrm{E}-04$

$\begin{array}{lll}6.5 E-04 & \text { Nonrad noncarcinogenic index sum: } \\ \text { NA } & \text { NA }\end{array}$

25

26

28 WAC 173-340 Evaluation (Waste Staging Pile Footprint)

29

30 3-Part Test:

$3195 \%$ UCL > Cleanup Limit?

$32>10 \%$ above Cleanup Limit?

33 Any sample $>2 \times$ Cleanup Limit?

NO

34

35 Risk Estimate:

36 Nonrad noncarcinogenic index sum:

37 Nonrad carcinogenic risk:

NO

3.4E-04

NA 
Rev. 0 


\section{Washington Closure Hanford}

Originator M. J. Appel 220 f $\%$ Project 100-F Area Field Refhediation Subject $118-\mathrm{F}-3$ Cleanup Verification $95 \%$ UCL Calculation

\section{CALCULATION SHEET}

Date 11/14/06 Job No. 14655

Calc. No. $0100 \mathrm{~F}-\mathrm{CA}-\mathrm{V} 0273$ Checked J.M. Capron Rev. No. $\frac{0}{11 / 5 / 56}$ Sheet No. 4 of 15

Summary (continued)

1 Results:

2 The results presented in the summary tables that follow are for use in the 118-F-3 CVP

4 Relative Percent Difference Results* QAVaC Analysis

\begin{tabular}{|c|c|c|c|c|c|c|c|c|c|c|c|}
\hline \multirow[b]{2}{*}{ Analyte } & \multicolumn{5}{|c|}{ Shallow Zone } & \multicolumn{3}{|c|}{ Overburden } & \multicolumn{3}{|c|}{ Waste Staging Pile Footprint } \\
\hline & $\begin{array}{c}\text { Duplicate } \\
\text { Analysis of } \\
\text { Sample } A 2^{\star \star}\end{array}$ & $\begin{array}{c}\text { Split Analysis } \\
\text { of Sample } \\
\mathrm{A2}^{\star \star}\end{array}$ & $\begin{array}{l}\text { EPA-Split } \\
\text { Anaiysis of } \\
\text { Sample A2*夫 }\end{array}$ & $\begin{array}{c}\text { EPA-Split } \\
\text { Analysis of } \\
\text { Sample A3 }{ }^{\star \star}\end{array}$ & $\begin{array}{c}\text { EPA-Split } \\
\text { Analysis of } \\
\text { Black Ash } \\
\text { Sample }\end{array}$ & $\begin{array}{l}\text { Duplicate } \\
\text { Analysis }^{\star \star}\end{array}$ & $\begin{array}{c}\text { Split } \\
\text { Analysis" }\end{array}$ & $\begin{array}{l}\text { EPA-Split } \\
\text { Analysis }\end{array}$ & $\begin{array}{l}\text { Duplicate } \\
\text { Analysis** }\end{array}$ & $\begin{array}{c}\text { Split } \\
\text { Analysis }\end{array}$ & $\begin{array}{l}\text { EPA-Split } \\
\text { Analysis** }\end{array}$ \\
\hline Aluminum & $8.9 \%$ & $19.6 \%$ & $61.0 \%$ & $73.0 \%$ & $118.0 \%$ & $6.9 \%$ & $19.8 \%$ & $51.0 \%$ & $10.6 \%$ & $33.1 \%$ & $71.0 \%$ \\
\hline Antimony & & & & & & & & & & & \\
\hline Arsenic & & & & & & & & & & & \\
\hline Barium & $6.5 \%$ & $12.0 \%$ & $79.0 \%$ & $29.0 \%$ & $25.0 \%$ & $10.7 \%$ & $12.3 \%$ & $9.0 \%$ & $7.4 \%$ & $10.1 \%$ & $11.0 \%$ \\
\hline Beryllium & & & & & & & & & & & \\
\hline Boron & & & & & & & & & & & \\
\hline Calcium & $2.4 \%$ & $3.9 \%$ & $25.0 \%$ & $22.0 \%$ & $13.0 \%$ & $4.7 \%$ & $1.1 \%$ & $200.0 \%$ & $9.6 \%$ & $9.8 \%$ & $43.0 \%$ \\
\hline Chromium Total & $19.9 \%$ & $0.0 \%$ & $36.0 \%$ & $54.0 \%$ & $73.0 \%$ & $5.8 \%$ & $28.6 \%$ & $28.0 \%$ & $12.9 \%$ & $24.9 \%$ & \\
\hline Cobalt & & & & & & & & & & & \\
\hline Copper & $3.4 \%$ & $4.3 \%$ & $18.0 \%$ & $35.0 \%$ & $45.0 \%$ & $0.0 \%$ & $2.3 \%$ & $22.0 \%$ & $10.7 \%$ & $7.5 \%$ & $34.0 \%$ \\
\hline Iron & $8.5 \%$ & $3.5 \%$ & $30.0 \%$ & $55.0 \%$ & $59.0 \%$ & $9.9 \%$ & $24.1 \%$ & $35.0 \%$ & $4.4 \%$ & $39.8 \%$ & $50.0 \%$ \\
\hline Lead & & & & & & & & & & & \\
\hline Magnesium & $5.9 \%$ & $16.5 \%$ & $23.0 \%$ & $47.0 \%$ & $33.0 \%$ & $8.7 \%$ & $16.7 \%$ & $22.0 \%$ & $8.5 \%$ & $23.5 \%$ & $38.0 \%$ \\
\hline Manganese & $10.4 \%$ & $5.9 \%$ & $16.0 \%$ & $18.0 \%$ & $31.0 \%$ & $5.8 \%$ & $3.5 \%$ & $16.0 \%$ & $2.3 \%$ & $14.2 \%$ & $19.0 \%$ \\
\hline Nickel & & & & & & & & & & & \\
\hline Potassium & & & & & & & & & & & \\
\hline Selenium & & & & & & & & & & & \\
\hline Silicon & $42.2 \%$ & $73.6 \%$ & & & & $2.3 \%$ & $24.7 \%$ & & $15.0 \%$ & $0.0 \%$ & \\
\hline Sodium & & & & & $62.0 \%$ & & & & & & \\
\hline \begin{tabular}{|l} 
Vanadium \\
\end{tabular} & $13.2 \%$ & $6.6 \%$ & $22.0 \%$ & $51.0 \%$ & $60.0 \%$ & $10.7 \%$ & $25.9 \%$ & $23.0 \%$ & $1.9 \%$ & $42.4 \%$ & $40.0 \%$ \\
\hline Zinc & $10.7 \%$ & $3.4 \%$ & $12.0 \%$ & $30.0 \%$ & $32.0 \%$ & $6.2 \%$ & $2.0 \%$ & $13.0 \%$ & $7.3 \%$ & $16.9 \%$ & $24.0 \%$ \\
\hline Cobalt-60 & & & & $12.0 \%$ & & & & & & & \\
\hline Cesium-137 & & & & & & & & & & & \\
\hline Nickel-63 & & & & & & & & & & & \\
\hline Europium-152 & & & & & & & & & & & \\
\hline Nickel-63 & & & NA & NA & NA & & & $\mathrm{NA}$ & & & NA \\
\hline Potassium-40 & $30.0 \%$ & & $41.0 \%$ & $8.0 \%$ & $47.0 \%$ & $45.0 \%$ & & $8.0 \%$ & $54.0 \%$ & & $1.3 \%$ \\
\hline Radium-226 & & & & & $73.0 \%$ & $40.0 \%$ & & $42.0 \%$ & $26.0 \%$ & & $51.1 \%$ \\
\hline Radium-228 & & & & & $23.0 \%$ & & & & & & \\
\hline Strontium-90 & & & & & & & & & & & \\
\hline Uranium-235 & & & & & & & & & & & \\
\hline
\end{tabular}

A Dhek cell incictes that RPD

39 "The signiilicance of the reported RPD values, including values greater than $30 \%$, is addressed within the Data Quality Assessment section of the CVP for this site

$\mathrm{NA}=$ not applicable
$\mathrm{Q} \mathrm{A} / \mathrm{QC}=$ quality as

$\mathrm{RPD}=$ relative percent difference 
CVP-2006-00008

Rev. 0

C-16 
Originator M. J. Appel M M

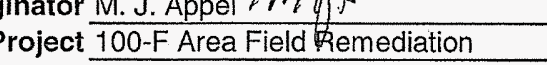

$11 / 14 / 06$

Job No. $\frac{114655}{1465}$

Calc. No. 0100F-CA-V0273
Checked J.M. Capron y 2 me

Rev. No. $\frac{0}{0}$

Subject $118-\mathrm{F}-3$ Cleanup Verification $95 \%$ UCL Calculations

\begin{tabular}{|c|c|c|c|c|c|c|c|c|c|c|c|c|c|c|c|c|c|c|c|}
\hline Sampling & Sample & Sample & & ariun & & & ioron & & & bbalt-1 & & & r-137 & & ckel-66 & & & Sntiu & , \\
\hline \begin{tabular}{|c|} 
Area \\
A1
\end{tabular} & Number & $\frac{\text { Date }}{8 / 1 / 106}$ & $\frac{\mathrm{mg} / \mathrm{kg}}{89.4}$ & $\bar{C}$ & $\frac{P Q L}{0.060}$ & $\frac{m g / k g}{78}$ & a & $\frac{P Q L}{0.70}$ & $\begin{array}{l}p \mathrm{Ci} / \mathrm{g} \\
0.120\end{array}$ & $\mid \frac{|a|}{|v|}$ & $\frac{M D A}{0.12}$ & $\frac{p c i / g}{0.121}$ & \begin{tabular}{l|l}
2 & MDA \\
2.090
\end{tabular} & $\frac{\mathrm{pCi/g}}{3.78}$ & & $\frac{M D A}{3.4}$ & $\frac{\text { pCilg }}{0.177}$ & \begin{tabular}{|l|}
$a$ \\
$u$ \\
\end{tabular} & $\begin{array}{l}\text { MDA } \\
0.21\end{array}$ \\
\hline$A_{2}$ & J134T9 & $8 / 2 / 206$ & 52.3 & C & 0.000 & 0.81 & & 0.100 & 0.140 & 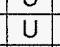 & 0.14 & $\frac{0.121}{0.110}$ & $\frac{0.096}{0.11}$ & $\begin{array}{l}3.18 \\
4.21\end{array}$ & & $\begin{array}{l}3.4 \\
3.2\end{array}$ & 0.177 & u & $\begin{array}{l}0.41 \\
0.44\end{array}$ \\
\hline A3 & J134T8 & $8 / 3 / 106$ & 116 & & 0.060 & 12.7 & $c$ & 0.70 & 0.378 & & 0.057 & 0.200 & 0.20 & 23.7 & & 4.2 & 0.276 & & 0.24 \\
\hline A4 & J134T7 & $8 / 3 / 106$ & 66.1 & c & 0.060 & 1.9 & & 0.69 & 0.042 & u & 0.042 & 0.160 & 0.049 & -0.764 & $u$ & 3.6 & 0.028 & $u$ & 0.21 \\
\hline $\begin{array}{c}\text { Duplicate of } \\
\text { J134T9 }\end{array}$ & J134V0 & $8 / 206$ & 49.0 & c & 0.060 & 1.2 & & 0.70 & 0.093 & $u$ & 0.093 & 0.094 & 0.069 & 2.06 & $u$ & 3.3 & -0.045 & $u$ & 0.39 \\
\hline
\end{tabular}

9
10

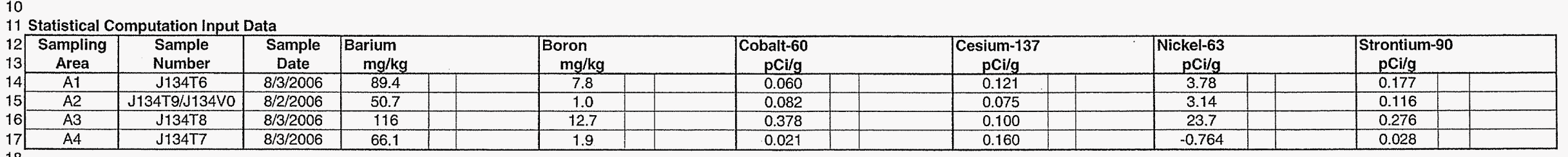

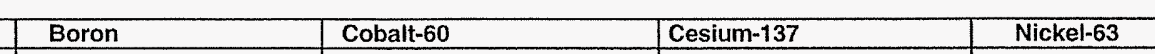
Strontium-90

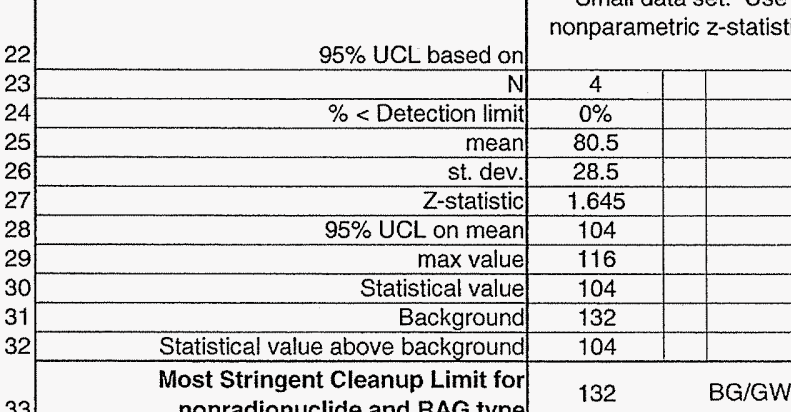
33 nonradionuclide and RAG type

35 WAC 173-340 3-PART Test $95 \%$ UCL > Cleanup Limit?

$\quad>10 \%$ above Cleanup Limit?
37 Any sample $2 \times$ Cleanup Limit? 39 WAC 173-340 NOOUATION

40 Hazzod

41 WAC 173-340 Carcinogenic Cleanus

42 Risk for each carcinogenic nonradionuclide:

43 WAC 173-340 3-Part-Test
Compliance?

Nonrad non

44 index sum:

YES

45 Nonrad carcinogenic risk:

6.5E-04

$46 \mathrm{BG}=$ background
$4 \mathrm{C}=$ analyte found in method blan

$48 \mathrm{GW}=$ groundwater
$49 \mathrm{NA}=$ not appicable

$\mathrm{m} / \mathrm{kg}$ ), calculation of

$\mathrm{PQL}=$ pracicical quantitation limit

$Q=$ qualifier
$R A G=$ remedial action goal

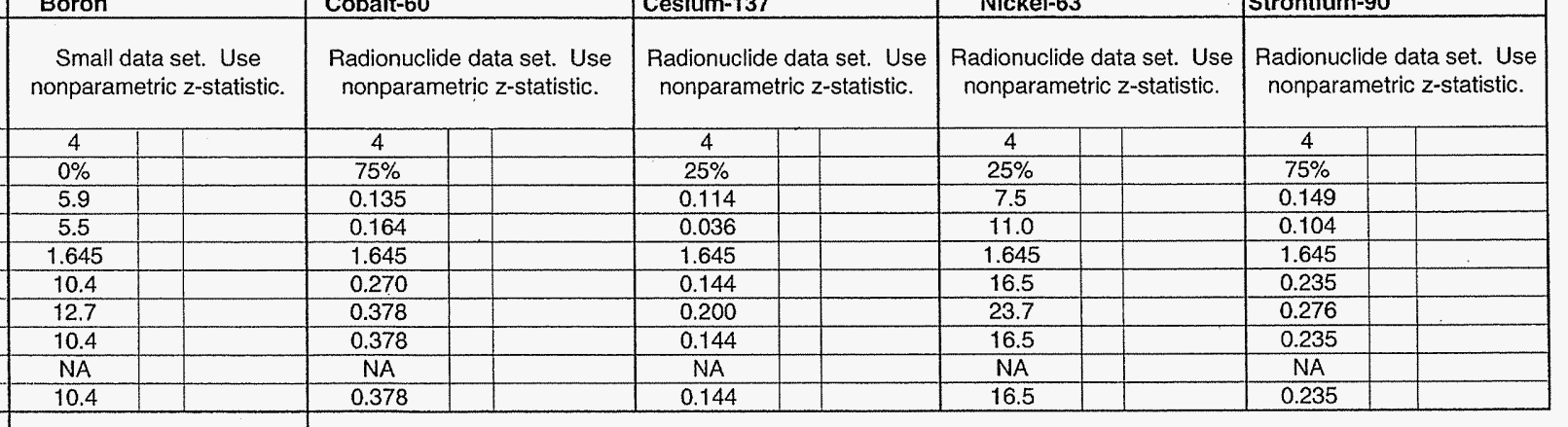

320 GW Protection

NO

5600

NA

$\mathrm{RAG}=$ remedial action goal

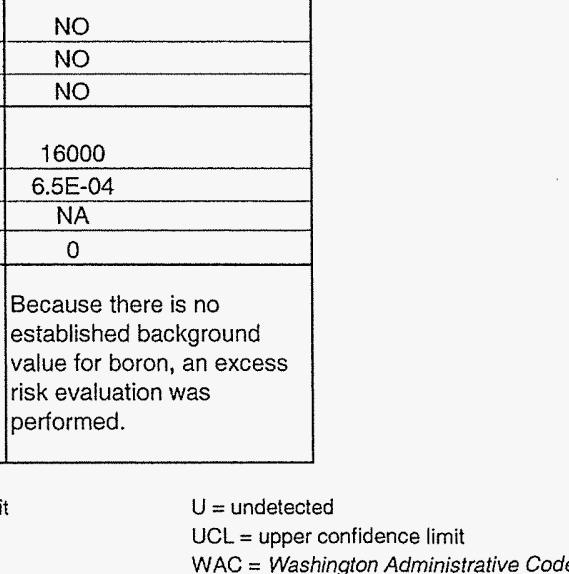




\section{Washington Closure Hanford}

Originator M.J.Appel M M PS

Pujection

UCL Calculations

Dat $11 / 14 / 00$ Job No. 14655

CALCULATION SHEET

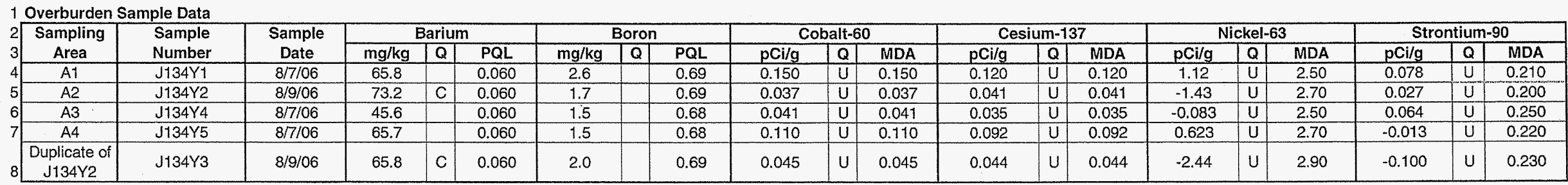
8

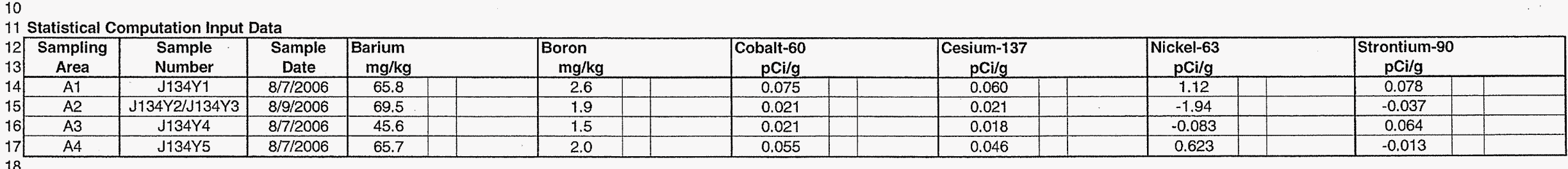

20 Statistical Computations

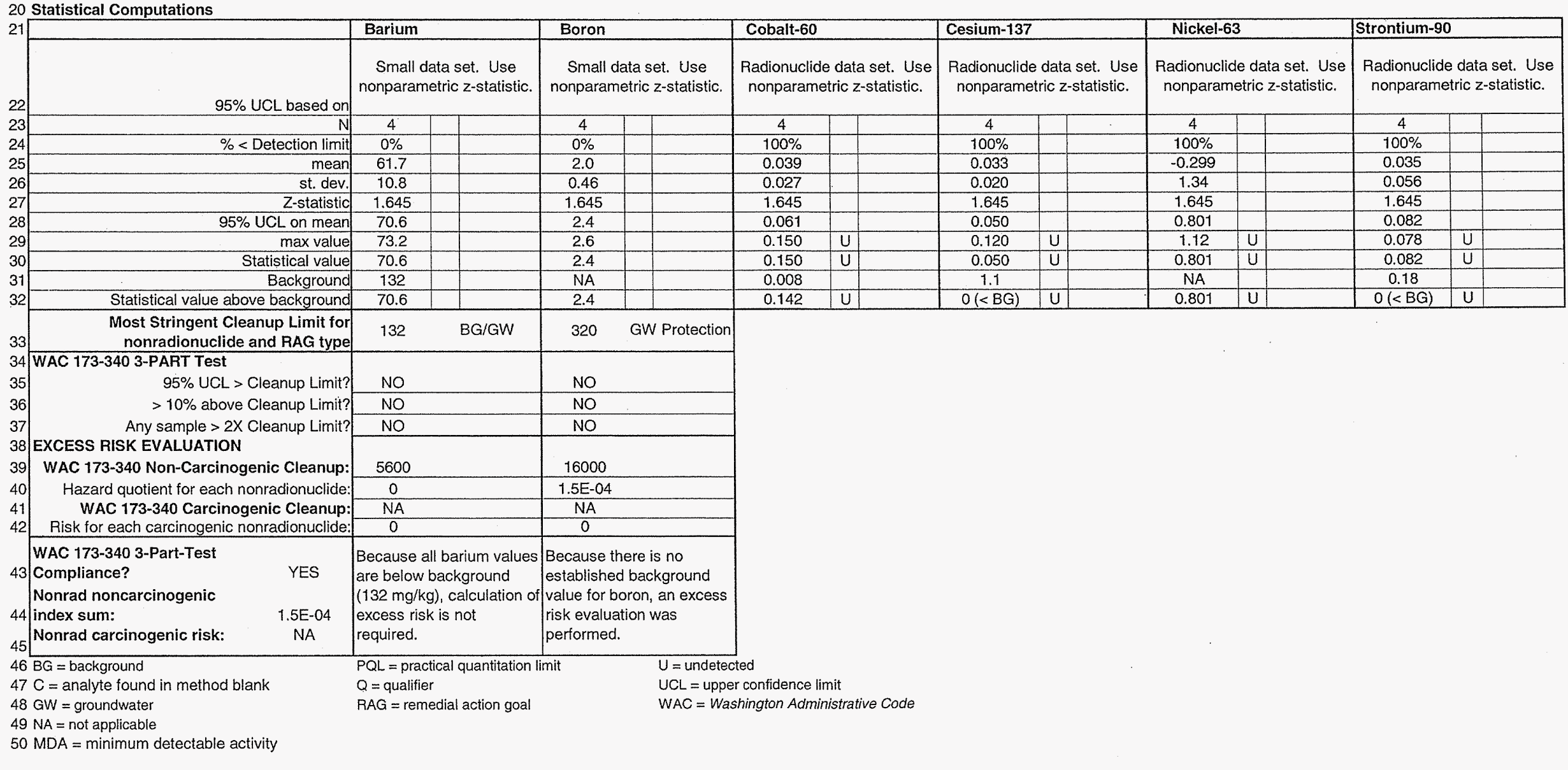




\section{Washington Closure Hanford}

Originator M.J.Appel M M N

Subject 118 -F-3 Cleanup Verification $95 \%$ UCL Calculation

Waste Staging Pile Footprint Sample Data

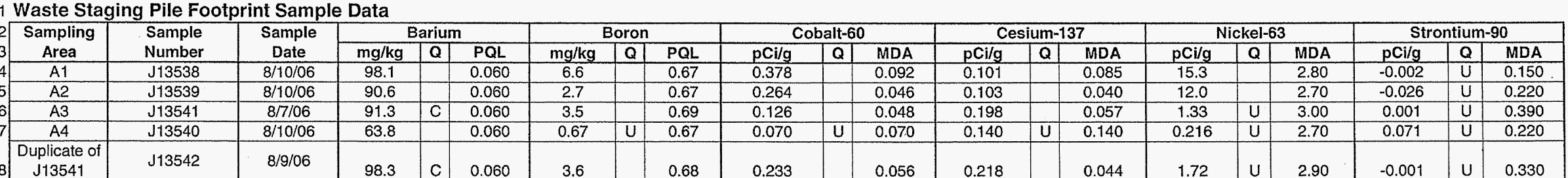

\section{9
10}

10
11 Statistical Computation Input Data
12

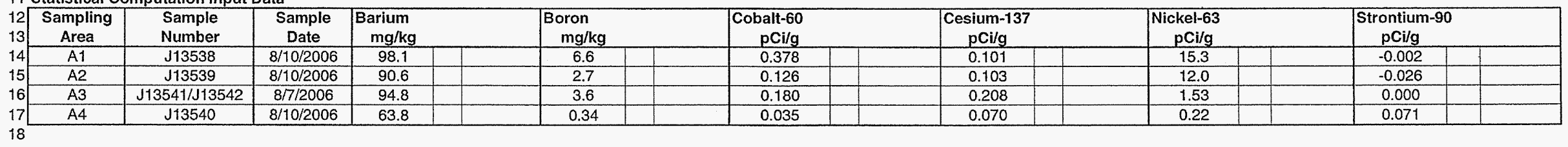

${ }_{20}^{19}$ Statistical Computations

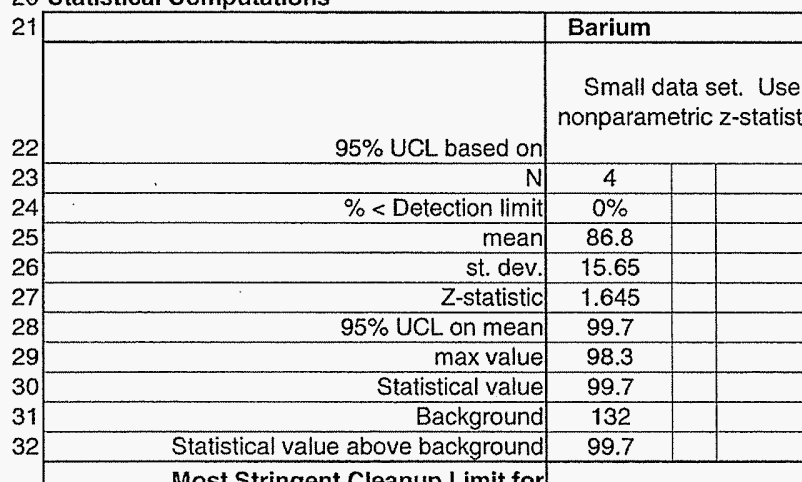

$33 \begin{array}{r}\text { Most Stringent Cleanup Limit for } \\ \text { nonradionuclide and RAG type }\end{array}$

$355 \quad 95 \%$ UCL > Cleanup Limit?

$>10 \%$ above Cleanup Limit?

38 EXCESS RISK EVALUATION

WAC 173-340 Non-Carcinogenic Cleanup.

Hazard quotient for each nonradionuclide:
WAC 173-340 Carcinogenic Cleanup:

RAC 173-340 3-Part-Test

43 Compliance?

Nonrad noncarcinogenic

45) Nonrad carcinogenic risk: $\quad 3.4 \mathrm{E}-04$

46 BG = background
$47 \mathrm{C}=$ analyre found in method blank
$48 \mathrm{DC}=$ direct contact

\begin{tabular}{|l|l|}
\hline $\begin{array}{l}\text { Because all barium values } \\
\text { are below background } \\
\text { 1izcause there is no } \\
\text { established background }\end{array}$ \\
\hline is
\end{tabular}

$49 \mathrm{GW}=$ groundwater
$50 \mathrm{MDA}=$ minimum detectable activity

$\mathrm{NA}=$ not applicable $\quad$ performed.

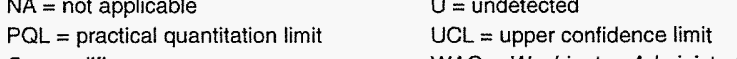

$Q=$ पualitier
$R A G=$ remedial action goal

UCL $=$ upper confidence limit
WAC = Washington Administrative Code

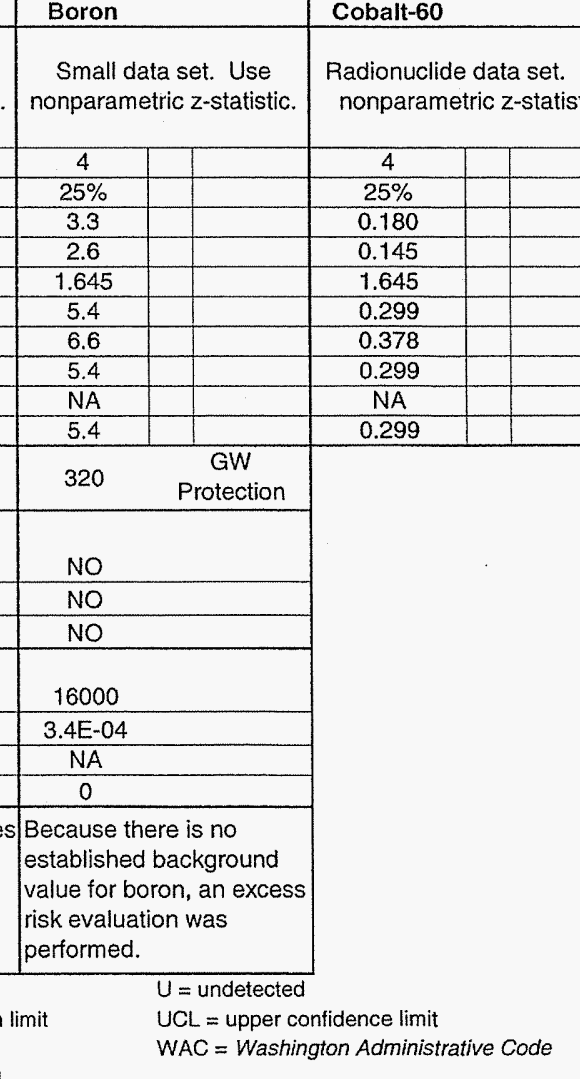


Originator M. J.Appel $m$ A

Project 100-F Area Field Remediation
Subject 1188-F-3 Cleanup Verification 95\% UCL Calculations
Date. 1114/4/06
Job No. 114655
Calc. No. 0100 F-CA-Vo273
Checked $\begin{aligned} & \text { Rev. No. } \frac{0}{\text { Date }} \\ & \text { Sheet No. } \frac{11 / 15 / 106}{8 \text { of } 15}\end{aligned}$

Split-Duplicate Analysis
1 Shallow Z Zne Sample Results: Non-radionuclides

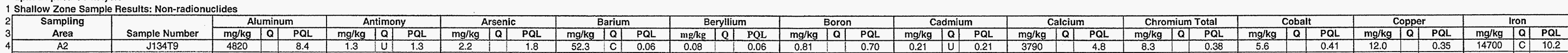

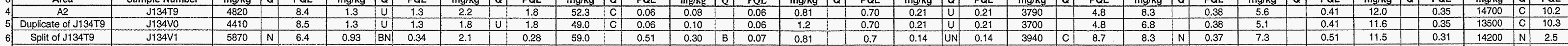

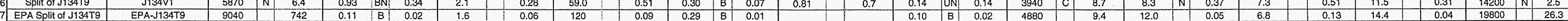

\begin{tabular}{|c|c|c|c|c|c|c|c|c|c|c|c|c|c|}
\hline \multirow{2}{*}{$\begin{array}{lll} & \text { Duplicate Analysis } \\
\end{array}$} & & 5 & 0.6 & 10 & 2 & 0.5 & 2 & 0.2 & 100 & & 2 & 1 & 5 \\
\hline & $\begin{array}{l}\text { Both } P \text { PLI? } \\
\text { Both } 5 \text { STTLL? }\end{array}$ & 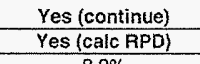 & No-Stop (acceptable) & No-Stop (acceptable) & 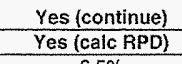 & 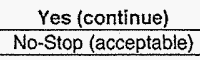 & 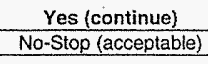 & No-Stop (acceptable) & $\begin{array}{l}\text { Yess (continue) } \\
\text { Yes (calc RPD) }\end{array}$ & $\begin{array}{l}\text { Yese (contitue) } \\
\text { Yes (calc nPD) }\end{array}$ & $\frac{\text { Yes (continue) }}{\text { No-Stop (acceperable) }}$ & $\begin{array}{l}\text { Yesc (continue) } \\
\text { Yes (calc RPD) }\end{array}$ & 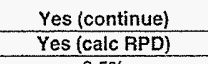 \\
\hline \multirow{2}{*}{ Split Analysis } & 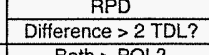 & 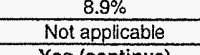 & No-accepalable & No-acceptable & No.5\% appicable & No- acceptable & No- acceptable & No - acceptable & $\begin{array}{l}2.4 \% \\
\text { Not apolcable } \\
\end{array}$ & $\begin{array}{l}\text { 19.9.\% } \\
\text { Not appicable }\end{array}$ & No- accepable & $\begin{array}{l}3.4 \% \\
\text { Notaplicab } \\
\end{array}$ & $\begin{array}{l}\frac{8.5 \%}{2} \\
\text { Not applicable }\end{array}$ \\
\hline & \begin{tabular}{|l} 
Difiference > 2 TDL? \\
Both
\end{tabular} & 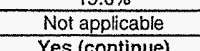 & No- acceptable & No- acceptable & 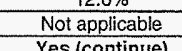 & 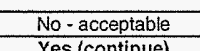 & $\frac{\text { No-acceptable }}{20}$ & No- acceptable & 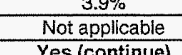 & 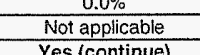 & 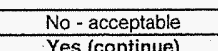 & 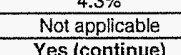 & 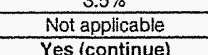 \\
\hline \multirow[t]{2}{*}{ EPA Split of J134T9 } & \begin{tabular}{|c|} 
Both $>$ 5xTDL? \\
APD
\end{tabular} & $\begin{array}{l}\text { Yes (calch RPD) } \\
\text { 60.9.9. }\end{array}$ & & & 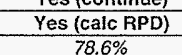 & No-stiop (accecoptable) & & & 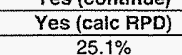 & 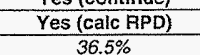 & No-Stop (acceptable) & 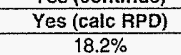 & $\begin{array}{l}\text { Yes (calc APD) } \\
29.6 \%\end{array}$ \\
\hline & Difiference > 2 TDL? & Not aplicable & No - acceptable & No- acceptable & Not applicable & No- acceptable & & No - acceptable & Not appicicale & Not apolicable & No- acceptiable & Not applicable & Not appicable \\
\hline
\end{tabular}

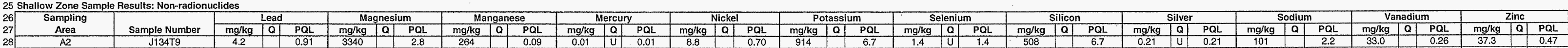

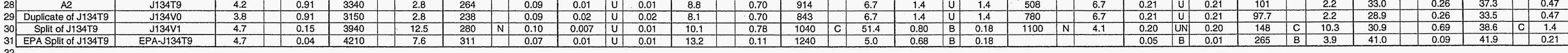
33 Sample Analysis:

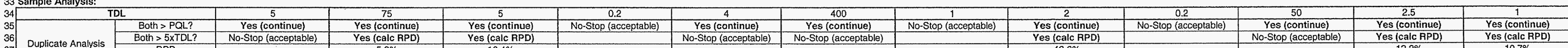

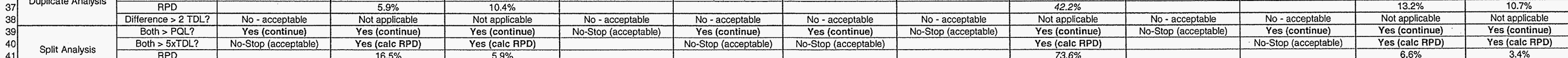

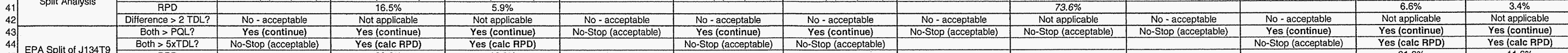

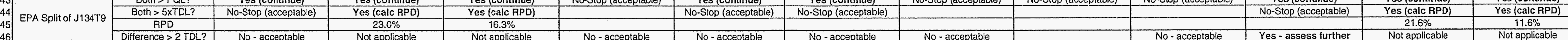

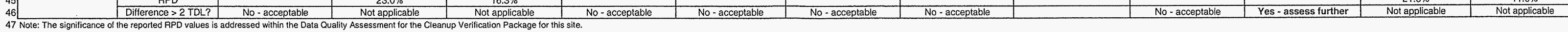

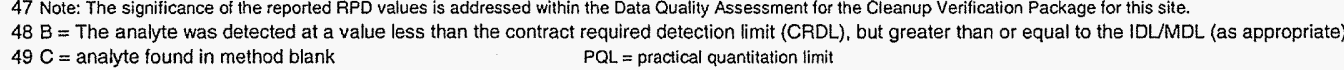

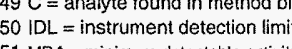

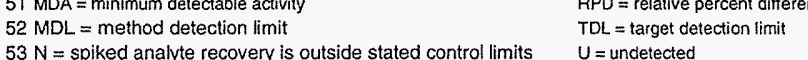

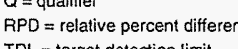




\section{Washington Closure Hanford}

Originator M. J. Appel $m g A$

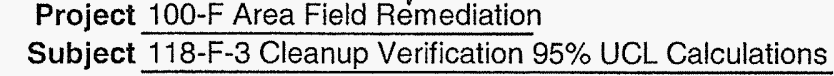

\section{CALCULATION SHEET}

Date 11/14/06

Job No. 14655
Calc. No. 0100F-CA-V0273

Checked J.M. Capron $2 \operatorname{men}$
Rev. No. $\frac{0}{11 / 5106}$

\section{Split-Duplicate Analysis}

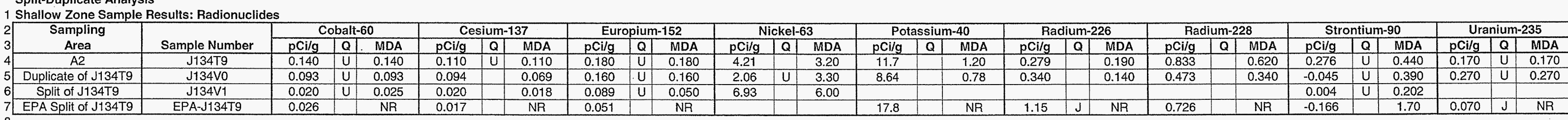

9 Sample Analysis:

\begin{tabular}{|c|c|c|c|c|c|c|c|c|c|c|}
\hline & DL & 0.05 & 0.1 & 0.1 & 30 & 0.5 & 0.1 & 0.2 & 1.0 & 1.0 \\
\hline \multirow{3}{*}{ Duplicate Analysis } & Both $>$ MDA? & No-Stop (acceptable) & No-Stop (acceptable) & No-Stop (acceptable) & No-Stop (acceptable) & Yes (continue) & Yes (continue) & Yes (continue) & No-Stop (acceptable) & No-Stop (acceptable) \\
\hline & $\begin{array}{c}\text { Both > 5xTDL? } \\
\text { RPD }\end{array}$ & & & & & $\begin{array}{l}\text { Yes (calc RPD) } \\
300\end{array}$ & No-Stop (acceptable) & No-Stop (acceptable) & & \\
\hline & Difference $>2 \mathrm{TDL}$ ? & No- acceptable & No - acceptable & No- acceptable & No- acceptable & Not applicable & No- acceptable & No- acceptable & No- acceptable & No - acceptable \\
\hline \multirow{3}{*}{ Split Analysis } & $\begin{array}{l}\text { Both > MDA? } \\
\text { Both }>\text { sTTDI }\end{array}$ & No-Stop (acceptable) & No-Stop (acceptable) & No-Stop (acceptable) & Yes (continue) & No-Stop (acceptable) & No-Stop (acceptable) & No-Stop (acceptable) & No-Stop (acceptable) & No-Stop (acceptable) \\
\hline & $\begin{array}{l}\text { Botin > 5xidu? } \\
\text { RPD }\end{array}$ & & & & No-Stop (acceptable) & & & & & \\
\hline & \begin{tabular}{|l|l|l|l|} 
\\
\end{tabular} & Yes - assess further & No-acceptable & No- acceptable & No-acceptable & & & & No- acceptable & \\
\hline \multirow[t]{2}{*}{ EPA Split Analysis } & $\begin{array}{l}\text { Both > MDA? } \\
\text { Both > 5TTDL? }\end{array}$ & No-Stop (acceptable) & No-Stop (acceptable) & No-Stop (acceptable) & & $\begin{array}{l}\text { No-Stop (accepplable) } \\
\text { Yes (calc RPD) }\end{array}$ & No-Stop (acceptable) & No-Stop (acceptable) & No-Stop (acceptable) & No-Stop (acceptable) \\
\hline & \begin{tabular}{|l} 
Difference $>2 \mathrm{TDL}$ \\
\end{tabular} & Yes-assess further & No- acceptable & No- acceptable & & Not applicable & Yes - assess further & No- acceptable & No - acceptable & No- acceptable \\
\hline 1DA = minimumum de & & 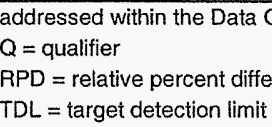 & & & & & & & & \\
\hline
\end{tabular}


Washinaton Closure Hanford

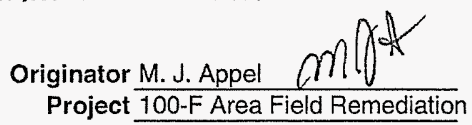

Subject 118-F-3 Cleanup Verification $95 \%$ UCL Calculations
CALCULATION SHEET
Calc. No. 0100F-CA-V0273
Checked $\frac{1}{\text { J.M. Capron gmL }}$
$\begin{aligned} \text { Rev. No. } \frac{0}{\text { Date }} & \frac{0}{11 / 15 / 06} \\ \text { Sheet No. } & \text { 10 of } 15\end{aligned}$

Date $11 / 14 / 06$
Job No. 14655

EPA Split Analysis

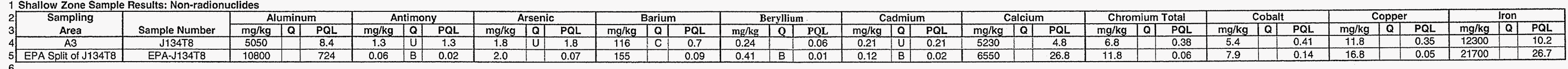

\begin{tabular}{|c|c|c|c|c|c|c|c|c|c|c|c|c|}
\hline & ${ }^{T} \mathrm{TL} \quad$ Both>PQL? & $\begin{array}{l}5 \\
\text { Yes (continue) }\end{array}$ & 0 & $\begin{array}{l}10 \\
\text { No-Stop (acceptable) }\end{array}$ & $\frac{2}{\text { Yes continu }}$ & $\begin{array}{c}0.5 \\
\text { Yes (continue) } \\
\end{array}$ & $\begin{array}{c}0.2 \\
\text { No-Stop (acceptable) }\end{array}$ & $\begin{array}{l}100 \\
\text { Yes (continue) }\end{array}$ & Yes (continue) & $\frac{2}{2} \frac{2}{T^{2} \text { (continue) }}$ & Yes (continue) & $\begin{array}{c}5 \\
\text { Yes (continue) } \\
\end{array}$ \\
\hline EPA Split of J134 & $\begin{array}{lll} & \text { Both }>55 \mathrm{TDL} \text { ? } \\
\end{array}$ & $\begin{array}{l}\text { Yes (cala CPDD) } \\
72.6 \%\end{array}$ & 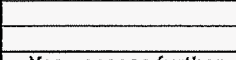 & & $\begin{array}{r}\text { Yes (calc RPD) } \\
299 \% \\
\end{array}$ & No.Stop (acceptatle) & & $\begin{array}{l}\text { Yes (cala RPD) } \\
22.4 \% 6\end{array}$ & $\begin{array}{l}\text { Yes ( (Ialc CPDD) } \\
55.8 \%\end{array}$ & $\begin{array}{l}\text { No-Siop (acceptatale) } \\
\end{array}$ & $\begin{array}{l}\text { Yeses(Calat RPP) } \\
35.0 \%\end{array}$ & 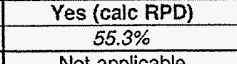 \\
\hline
\end{tabular}

\section{EPA Split Analysis}

16 Shallow Zone Sample Results: Non-radionuclides
17
17

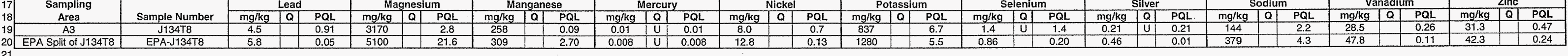

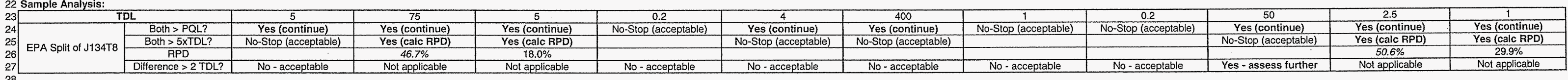

\section{${ }_{30}^{29}$ EPA Split Analys}

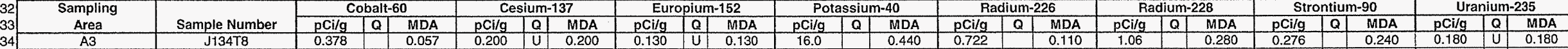

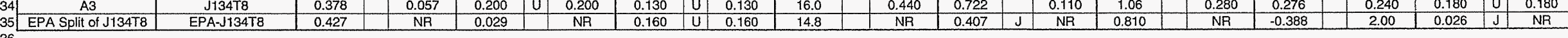

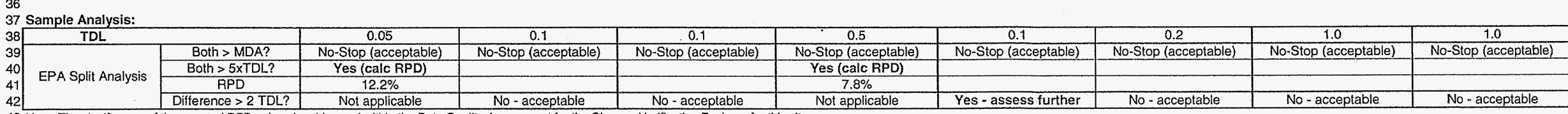

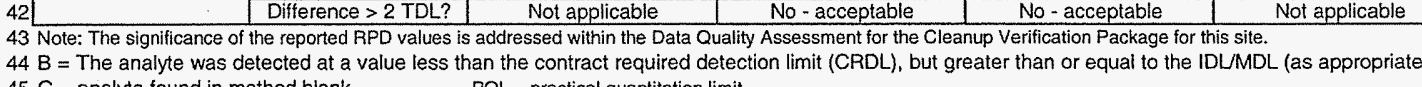

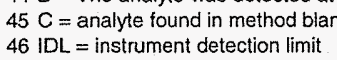

$48 \mathrm{MD}=$ minimum detectable activity
$49 \mathrm{MDL}=$ metrod d detection linit

$a=$ =ualifier

$49 \mathrm{MDL}=$ method detection limit
$50 \mathrm{NB}=$ not reported

$\mathrm{D} L=$ target detection linit
Thit 


\section{Washington Closure Hanford}

$\underset{\text { Oroject }}{\text { Originato. Appel } m \text { 100-F Area Field Remediatio }}$

Subject $\frac{100-F \text { Area Field Remediation }}{118-F-3 \text { Cleanup Verification } 95 \% \text { UCL Calculations }}$
CALCULATION SHEET
Date $11 / 14 / 06$
Job No. 14655
Rev. No.
Date
Sheet No.
$\frac{11 / 15 / 06}{11 \text { of } 15}$

\section{EPA Split Analysis}

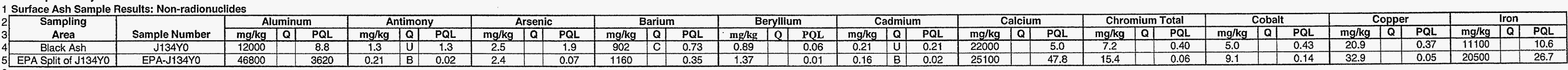
7 Sample Analysis:

\begin{tabular}{|c|c|c|c|c|c|c|c|c|c|c|c|c|}
\hline \multirow{3}{*}{ EPA Split of J J344C } & (2) & & 0.6 & & & & 0.2 & $\begin{array}{l}100 \\
\end{array}$ & & 2 & & Yosc contipural \\
\hline & 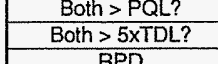 & 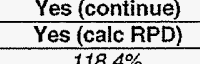 & No-Stop (acceptable) & $\begin{array}{l}\text { Yes (continue) } \\
\text { No-stop (acceptable) }\end{array}$ & $\begin{array}{l}\text { Yes (continue) } \\
\text { Yes (calc RPD) }\end{array}$ & $\frac{\text { Yes (continue) }}{\text { No-Stop (acceptable) }}$ & No-Stop (acceptable) & 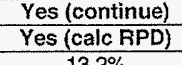 & 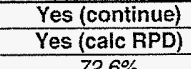 & $\begin{array}{l}\text { Yres (continue) } \\
\text { No-Stop (acopeptable) }\end{array}$ & $\begin{array}{l}\text { Yes (contine) } \\
\text { Yes (calle RPD) }\end{array}$ & 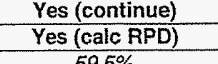 \\
\hline & Difference $>2$ TDL? & 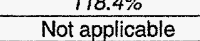 & No - acceptable & No-acceptable & $\begin{array}{l}25.0 \% \\
\text { Not apolicable }\end{array}$ & No- acceptable & No-acceptable & $\begin{array}{l}13.2 \% \\
\text { Not apolicable }\end{array}$ & & Yes - assess further & Not applicable & Not applicable \\
\hline
\end{tabular}

15 EPA Split Analysis

(1)

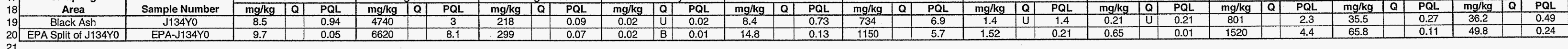
22 Sample Analysis:

\begin{tabular}{|c|c|c|c|c|c|c|c|c|c|c|c|c|}
\hline \multirow{2}{*}{ 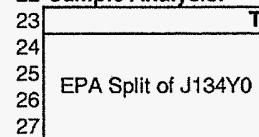 } & Both > PQL? & Yes (continue) & Yes (continue) & Yes (continue) & No.Stop (acceptable) & Yes (continue) & Yes (continue) & No-Stop (acceptable) & No-Stop (accepptable) & Yes (continue) & 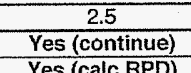 & $\begin{array}{l}\text { Yes (continue) } \\
\text { Yog (calc BPDD) }\end{array}$ \\
\hline & \begin{tabular}{|c} 
Both $>5 \times$ XTLL? \\
RPD \\
\end{tabular} & No-Stop (acceptable) & $\begin{array}{c}\text { Yes (calc CPD) } \\
33.1 \%\end{array}$ & $\begin{array}{l}\text { Yes (calc PAD) } \\
31.3 \% \\
\end{array}$ & & No-Stop (acceptable) & No-Stop (acceptable) & & & $62.0 \%$ & 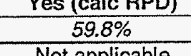 & 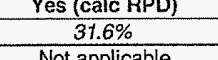 \\
\hline
\end{tabular}

\section{EPA Split Analysis}

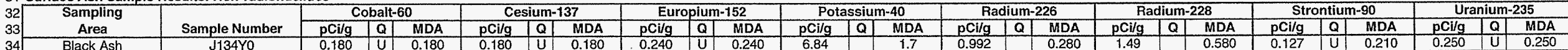

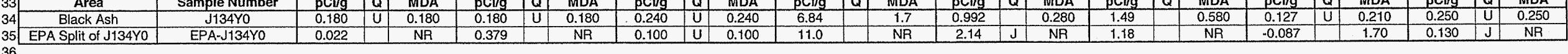

37 Sample Analysis:

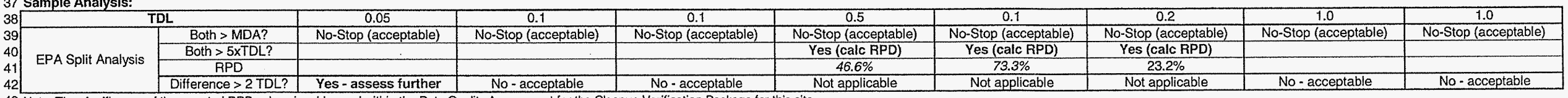

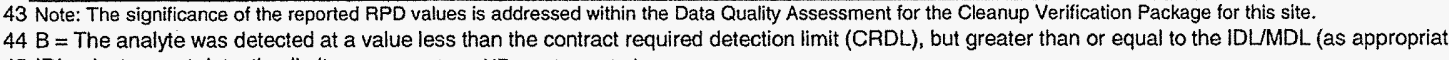

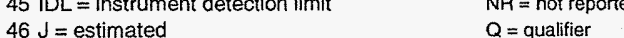

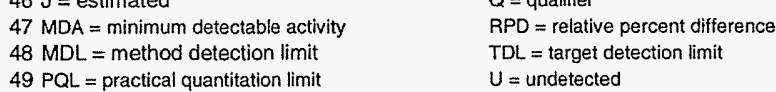


Washington Closure Hanford

Originator M. J. Appel M M I A

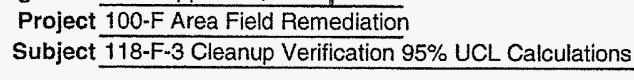

Solt-Duplicate Analysis

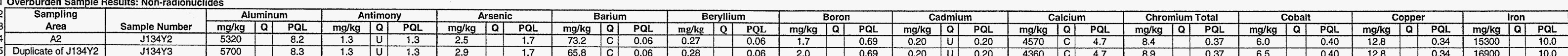

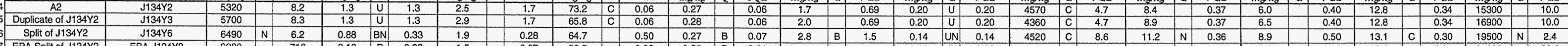

\begin{tabular}{|c|c|c|c|c|c|c|c|c|c|c|c|c|c|}
\hline \multirow[t]{2}{*}{ - } & & 5 & 0.0 & 10 & 2 & 0.5 & 2 & & 100 & & & & 5 \\
\hline & \begin{tabular}{|c} 
Both $>$ PaL? \\
Both $5 \times$ XTDL? \\
\end{tabular} & $\frac{\text { Yes (Continue) }}{\text { Ves (calc } R \text { CPD) }}$ & No-Stop (acceptable) & $\begin{array}{c}\text { Yes (continue) } \\
\text { No-Stop (acceptable) }\end{array}$ & $\begin{array}{l}\text { Yes (Continue) } \\
\text { Yes (calc RPDO) }\end{array}$ & $\begin{array}{l}\text { Yes (continue) } \\
\text { No-Stop (acceptable) }\end{array}$ & $\begin{array}{c}\text { Yes (continue) } \\
\text { No-Stop (acceptable) }\end{array}$ & No-Stop (acceptable) & $\begin{array}{l}\text { Yes (continue) } \\
\text { Yes (calc RPD) }\end{array}$ & $\begin{array}{l}\text { Yes (continue) } \\
\text { Yes (calc RPDD) }\end{array}$ & $\begin{array}{c}\text { Yes (continue) } \\
\text { No-Stop (acceptable) }\end{array}$ & $\begin{array}{l}\text { Yes (continue) } \\
\text { Yes (calc PPD) }\end{array}$ & $\begin{array}{l}\frac{\text { Yes (continue) }}{\text { Yes (calc RPD) }} \\
\text { Yons }\end{array}$ \\
\hline & $\begin{array}{l}\text { Difference }>2 \text { TDL? } \\
\end{array}$ & 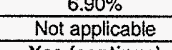 & No - acceptable & No-accepatable & Not abpicicable & No- $-\frac{1}{2}$ & & No - acceptable & $\begin{array}{l}4.7 \% \\
\text { Not appicable }\end{array}$ & $\begin{array}{c}5.8 \% \\
\text { Not applicable }\end{array}$ & & & \\
\hline Split Analysis & \begin{tabular}{|c} 
Both > PQL? \\
Both $>5 \times \mathrm{TLL2}$ ? \\
\end{tabular} & $\begin{array}{l}\text { Yrses (continue) } \\
\text { Yes (Calc RPD) }\end{array}$ & No-Siop (acceptable) & & $\begin{array}{l}\text { Yese (continue) } \\
\text { Yes (calc nPD) }\end{array}$ & $\begin{array}{l}\text { Yes (contitue) } \\
\text { No-Stop (acceptable) }\end{array}$ & 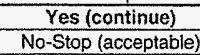 & No-Sio (acceptable) & 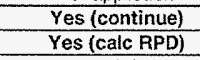 & 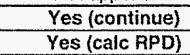 & $\begin{array}{l}\text { Yes (continue) } \\
\text { No-Sito (accetatiate) }\end{array}$ & 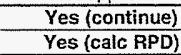 & $\begin{array}{l}\text { Yestic } \\
\text { Yostic }\end{array}$ \\
\hline & \begin{tabular}{|l} 
Difference $>2$ TDL \\
\end{tabular} & $\begin{array}{l}19.8 \% \\
\text { Not applicable }\end{array}$ & No- acceptable & No- acceptable & $\begin{array}{l}12.3 \% \\
\text { Not applicable }\end{array}$ & No- acceptat & No- acceptable & No - accopatable & $\begin{array}{c}1.1 \% \% \\
\text { Not applicable }\end{array}$ & & & & \\
\hline EPA Splitit of J13422 & 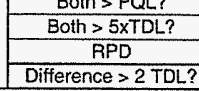 & 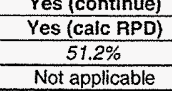 & & No-accepable & 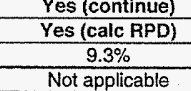 & $\begin{array}{c}\text { Yes contitue) } \\
\text { No-Stop (acceptable) } \\
\text { No - acceptable }\end{array}$ & & No - acceptable & 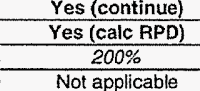 & 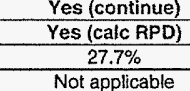 & 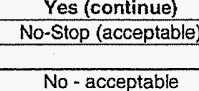 & 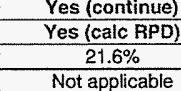 & 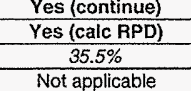 \\
\hline
\end{tabular}

25 Shallow Zone Sample Results: Nonradionuclides
Sampling

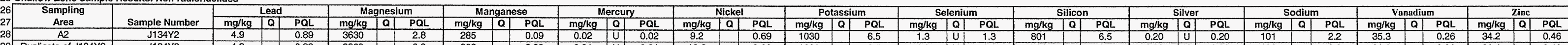

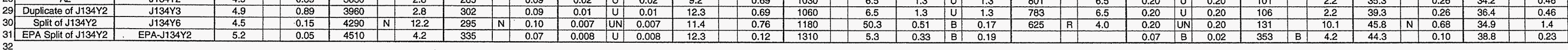
33 Sample Analysis:

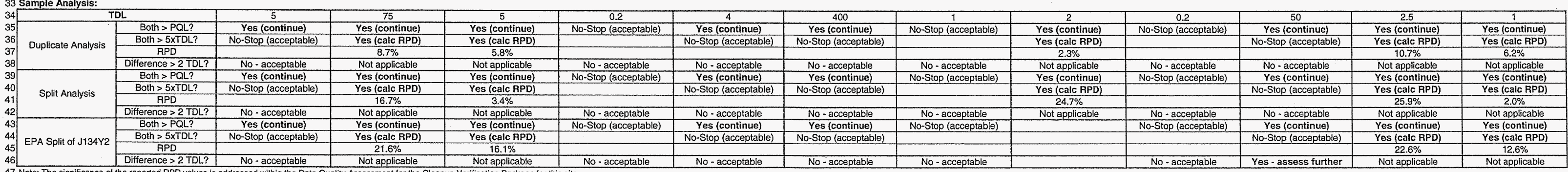

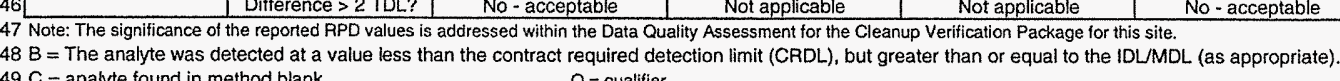

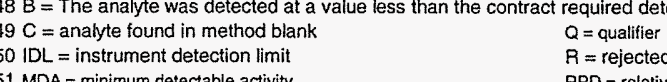

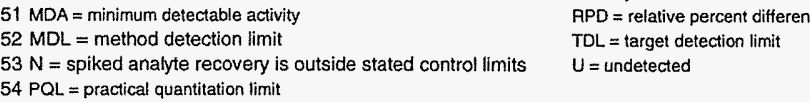

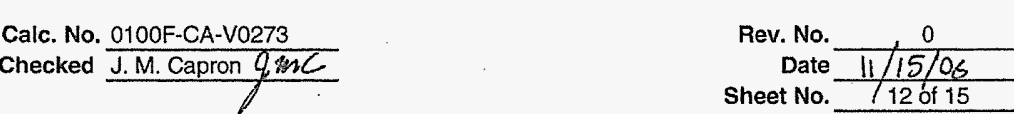


Washinaton Closure Hanford

Originator M. J. Appel MIP

Remediation

Subject 118-F-3 Cleanup Verification $95 \%$ UCL Calculations
Date $11 / 14 / 06$
Job No. 14655

(n)

\section{CALCULATION SHEET}

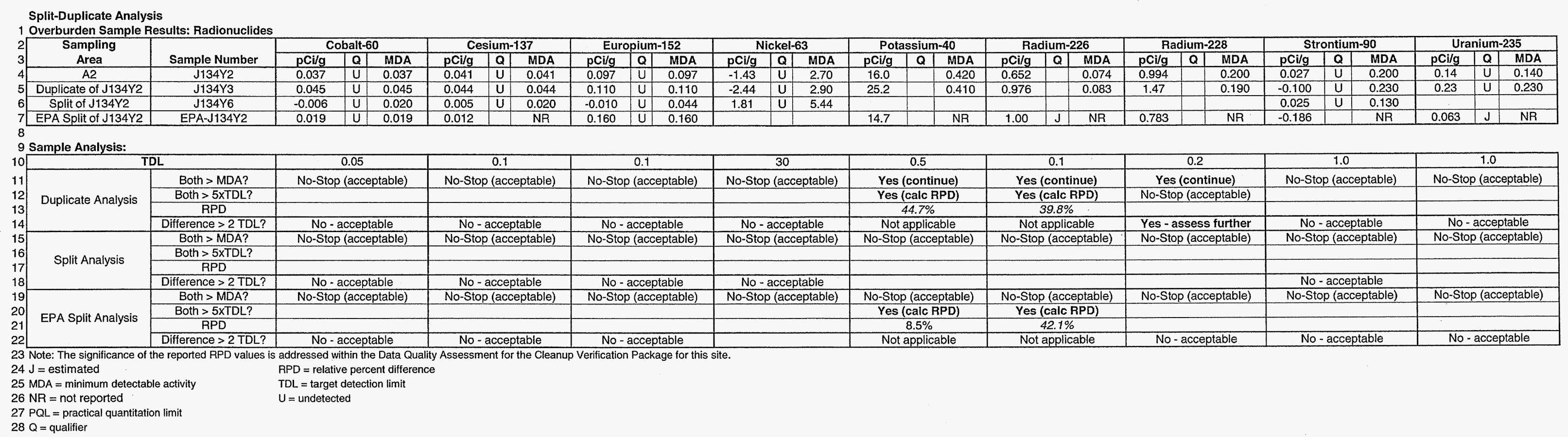

Rev. No. $\frac{0}{11 / 15 / 06}$ 


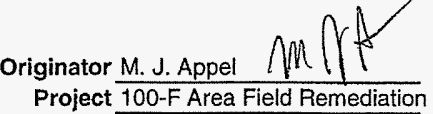

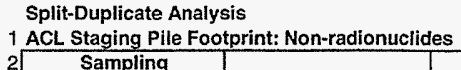

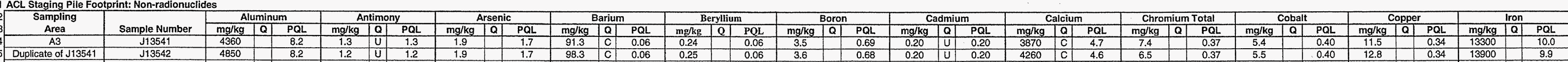

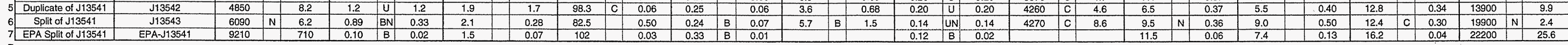

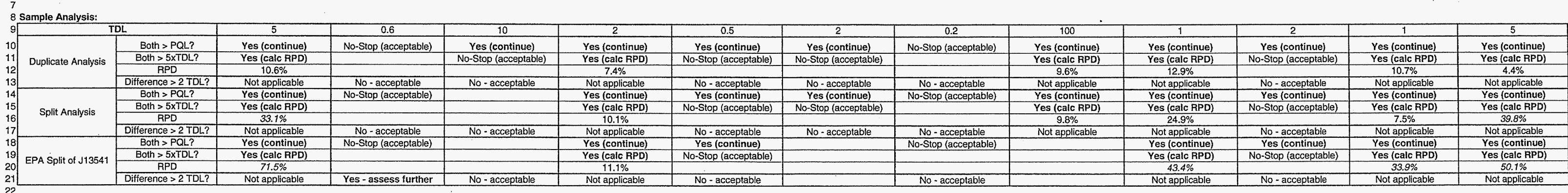
22 ${ }_{24}^{23}$ Split-Dupicate Analysis

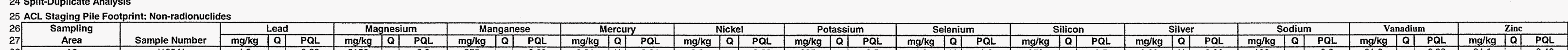

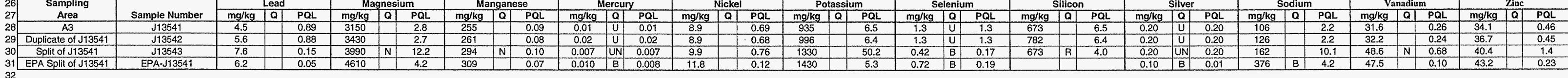

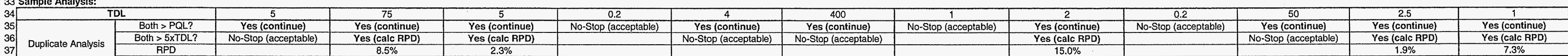

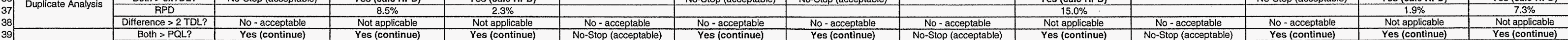

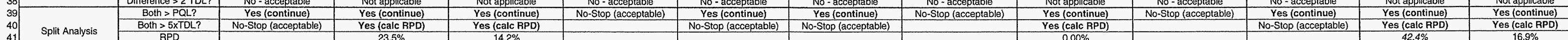

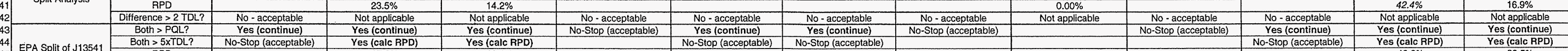

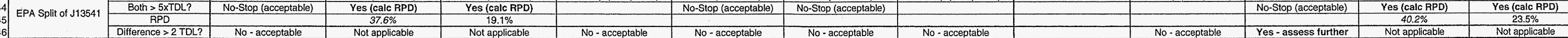

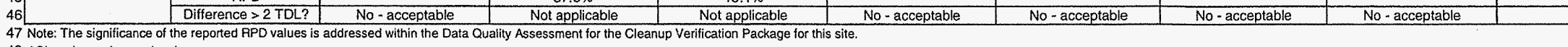

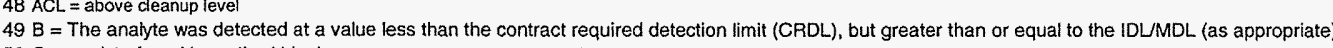

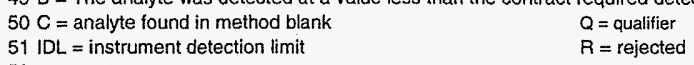

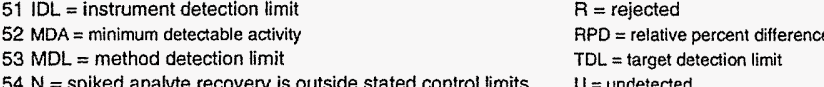

$54 \mathrm{~N}$ spiked analyte recovery i

Goutside stated conrol linits $\quad U$ unndetected 


\section{Washington Closure Hanford}

Originator M. J. Appel M $M Y$ Project 100-F Area Field Remediation Subject 118 -F-3 Cleanup Verification $95 \%$ UCL Calculations
CALCULATION SHEET

Date $11 / 14 / 06$

Job No. 14655
Calc. No. $0100 \mathrm{~F}-\mathrm{CA}-\mathrm{V} 0273$

Checked J.M. Capron Q m/
Rev. No. $\frac{0}{0}$

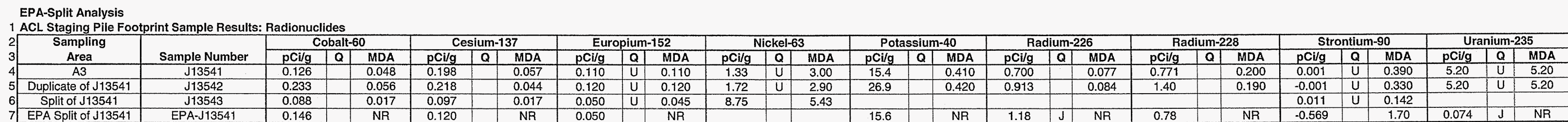

\begin{tabular}{|c|c|c|c|c|c|c|c|c|c|c|}
\hline ple Analysis: & & 0.05 & 0.1 & 0.1 & 30 & 0.5 & & 0.2 & 1.0 & \\
\hline \multirow{3}{*}{$\begin{array}{l}11 \\
13 \\
13\end{array}$ Duplicate Analysis } & Both > MDA? & Yes (continue) & Yes (continue) & No-Stop (acceptable) & No-Stop (acceptable) & Yes (continue) & Yes (continue) & Yes (continue) & No-Stop (acceptable) & No-Stop (acceptable) \\
\hline & $\begin{array}{l}\text { Both > 5xTDL? } \\
\text { BPD }\end{array}$ & No-Stop (acceptable) & No-Stop (acceptable) & & & Yes (calc RPD) & Yes (calc RPD) & No-Stop (acceptable) & & \\
\hline & Difference $>2 \mathrm{TDL}$ ? & Yes - assess further & No - acceptable & No - acceptable & No - acceptable & $\begin{array}{l}\text { Not taplicable } \\
\end{array}$ & Not applicable & Yes - assess further & No - acceptable & No- acceptable \\
\hline \multirow{2}{*}{ Split Analysis } & $\begin{array}{c}\text { Both > MDA? } \\
\text { Both > 5xTDL? }\end{array}$ & $\begin{array}{l}\text { Yes (continue) } \\
\text { No-Stop (acceptable) }\end{array}$ & $\begin{array}{l}\text { Yes (continue) } \\
\text { No-Stop (accetable }\end{array}$ & No-Stop (acceptable) & No-Stop (acceptable) & No-Stop (acceptable) & No-Stop (acceptable) & No-Stop (acceptable) & No-Stop (acceptable) & No-Stop (acceptable) \\
\hline & RPD & & mentabre & Ne smontonl & & & & & & \\
\hline \multirow{3}{*}{ EPA Split Analysis } & Both > MDD? & No-Stop (acceptable) & No-Stop (acceptable) & No-Stop (acceptable) & No-Stop (acceptable) & 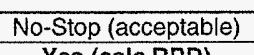 & No-Stop (acceptable) & No-Stop (acceptable) & No-Stop (acceptable) & No-Stop (acceptable) \\
\hline & $\begin{array}{l}\text { Both > 5xD } \\
\text { RPD ? }\end{array}$ & & & & & & $\begin{array}{c}\text { res (factipl) } \\
51.1 \%\end{array}$ & & & \\
\hline & Difference > 2 TDL? & No - acceptable & No-acceptable & ceptable & & Not applicable & Not applicable & No - acceptable & No - acceptable & Yes - assess further \\
\hline
\end{tabular}
23 Note: The signifificance of $24 \mathrm{ACL}=$ above cleanup leve

$26 \mathrm{MDA}=$ minimum detectable activity

$27 \mathrm{NR}=$ not reported
$28 \mathrm{PQL}=$ practical quantitation lim

$Q=$ qualifier

$\mathrm{RPD}=$ relative percent difference 


\section{DISTRIBUTION}

U.S. Department of Energy

Richland Operations Office

D. C. Smith (5)

A3-04

DOE-RL Public Reading Room

$\mathrm{H} 2-53$

Fluor Hanford, Inc.

J. P. Shearer (WIDS)

A0-21

Washington Closure Hanford

M. J. Appel

$\mathrm{H} 4-23$

M. A. Buckmaster

X9-07

S. W. Callison

$\times 9-07$

R. A. Carlson

$\times 4-08$

S. W. Clark

$\mathrm{H} 4-23$

J. S. Decker

X4-08

L. A. Dietz

$\mathrm{H} 4-22$

L. M. Dittmer

$\mathrm{H} 4-23$

M. T. Hughes

$\mathrm{H} 4-23$

J. E. Thomson

$\mathrm{H} 4-22$

Records and Document Control

H4-11

Hanford Technical Library

P8-55 
Rev. 0

Distr-2 